\title{
AUNC
}

Zabytkoznawstwo i Konserwatorstwo XLIX

Toruń 2018

DOI: http://dx.doi.org/10.12775/AUNC_ZiK.2018.001

\section{Sztuka złotnicza w Prusach. Próba charakterystyki złotnictwa regionu*}

\author{
MICHAŁ F. WOŹNIAK \\ Zakład Muzealnictwa \\ Wydział Sztuk Pięknych, UMK w Toruniu \\ e-mail:mwozniak@umk.pl \\ ORCID: 0000-0002-6923-1910
}

Key words: goldsmithing, State of the Teutonic Order in Prussia, Royal Prussia, Duchy of Prussia

Słowa kluczowe: złotnictwo, Prusy Zakonne, Prusy Królewskie, Prusy Książęce

\section{Abstract \\ Art of goldsmithing in Prussia. An attempt to characterize goldsmithery of the region.}

This article attempts to characterize the art of goldsmithing in Prussia from its beginnings in the late medieval period (ca. 1300) until the end of craft production in the late $18^{\text {th }}$ century. It does not aim to present a thorough chronological and typological overview of the subject. Instead, by presenting a collection of case studies which include individual items, groups of works and the oeuvre of the major goldsmiths, the author hopes to identify and analyze characteristic traits of the region's goldsmith production. What is more, he aims to define distinct qualities of the local production

Artykuł jest zmienioną wersją tekstu pt. „Goldschmiedekunst in Preußen - zur Frage der Regionalität“, przygotowanego do tomu studiów dedykowanych Rainerowi Kahsnitzowi, który ukaże się latem 2019 r. jako nr 69/70 „Zeitschrift des Deutschen Vereins für Kunstwissenschaft“ . Prof. dr Rainer Kahsnitz w ciągu swej wieloletniej aktywności naukowej (muzealnej i uniwersyteckiej), ze szczególnym akcentem na sztukę wczesnego i dojrzałego średniowiecza (malarstwo i rzemiosło artystyczne), a także późnogotycką plastykę (w tym twórczość Wita Stwosza), przejawiał szczególne zainteresowanie sztuką regionu pruskiego (nie bez związku z osobistymi doświadczeniami i indywidualną pamięcią o wydarzeniach połowy XX w.). Szkic ten, przez określenie niektórych węzłowych problemów, stanowi fazę przygotowawczą do planowanej pogłębionej syntezy dziejów sztuki złotniczej w Prusach. 
on the one hand and its links with other artistic centers on the other. This article is intended as a primer to a broader and more thorough study of the art of goldsmithing in the State of the Teutonic Order in Prussia, Royal Prussia, and the Duchy of Prussia.

\begin{abstract}
Abstrakt
Artykuł stanowi próbę charakterystyki sztuki złotniczej w regionie pruskim od jej uchwytnych początków w okresie późnego średniowiecza, od ok. 1300 roku, po kres wytwórczości cechowej u schyłku XVIII wieku. Celem nie jest zatem chronologicznie i typologicznie uporządkowany przegląd całej dawnej wytwórczości złotniczej w jej charakterystycznych przejawach. Autor na podstawie wybranych i reprezentatywnych przykładów - pojedynczych zabytków, ich grup lub twórczości znaczących przedstawicieli tej gałęzi sztuki - stara się wydobyć i określić cechy typowe dla złotnictwa regionu. Wskazuje przy tym na odrębności lokalne, ale i na powiązania z innymi środowiskami artystycznymi. W zamierzeniu autora tekst ten jest studium przygotowawczym do szerszego i kompletnego opracowania monograficznego złotnictwa w Prusach (Zakonnych, Królewskich i Książęcych.
\end{abstract}

Prusy zostały włączone w obręb łacińskiej i chrześcijańskiej cywilizacji europejskiej stosunkowo późno, dopiero poczynając od drugiej ćwierci XIII wieku. Już jednak w następnym stuleciu inwestorzy i zleceniodawcy dzieł sztuki: zakon krzyżacki, Kościół i miasta - prężnie się rozwijające i podejmujące ożywioną wymianę handlową zwłaszcza w obszarze hanzeatyckim - wchodziły w wielorakie relacje ze środkowo- i zachodnioeuropejskimi środowiskami artystycznymi, zwłaszcza na terenie Rzeszy. Do Prus docierały w postaci importów gotowe dzieła sztuki, ale także przybywali wykształceni artyści. O ile w zakresie sztuk plastycznych, rzeźby i malarstwa dużą rolę odgrywały Meklemburgia, Turyngia, Hesja, Nadrenia, Czechy, o tyle dla złotnictwa szczególne znaczenie w sferze zależności i oddziaływań miały nie tylko Dolna Nadrenia oraz sąsiednia Westfalia - co było bliskie wspomnianym powiązaniom, ale też region górnoreński ${ }^{1}$.

Historyczny zalążek i początkowe centrum państwa zakonnego w Prusach stanowiła ziemia chełmińska, a jego planowaną stolicą miało być Chełmno - z ambitnie wykreślonym planem miasta, z nadanym prawem miejskim (1233), wzorcowym dla innych miast pruskich. Ten aspekt prawny powiódł się zresztą w całej okazałości: na podstawie prawa chełmińskiego, będącego

1 Kinga Szczepkowska-Naliwajek, Złotnictwo gotyckie Pomorza Gdańskiego, ziemi chełmińskiej $i$ Warmii (Studia z Historii Sztuki, t. 40, red. Wiesław Juszczak et al.) (Wrocław-Warszawa-Kraków-Gdańsk-Łódź: Ossolineum, 1987); Johann Michael Fritz, Goldschmiedekunst der Gotik in Mitteleuropa (München: Verlag C. H. Beck, 1982). 
korzystną dla osadników i mieszkańców modyfikacją prawa magdeburskiego, założono szereg miast i wsi, nie tylko w Prusach. Stosunkowo wcześnie, może już od połowy, a najpóźniej od trzeciej ćwierci XIII wieku na czołowe miejsce nie tylko pośród ośrodków miejskich ziemi chełmińskiej, ale całego państwa zakonnego wysunął się Torun. Założony równocześnie z Chełmnem, już w 1264 roku został bez mała podwojony przez lokowanie Nowego Miasta, co świadczy o jego szybkim intensywnym rozwoju i o korzystnym położeniu, które pozwoliło na zajęcie pozycji regionalnego centrum gospodarczego. Motorem rozwoju były szybko nawiązane relacje handlowe zarówno w górę Wisły, z Krakowem i zapleczem polskim, jak i z portami bałtyckimi - nadrzeczny port toruński, oddalony od Bałtyku o 150 kilometrów w linii prostej (trasą wiślaną o około $230 \mathrm{~km}$ ), miał status portu morskiego, dostępnego dla ówczesnych kog handlowych. Ważną rolę w zakresie wytwórczości rzemieślniczej (i handlu dalekosiężnego) odegrały miasta położone nad Zalewem Wiślanym. Był to przede wszystkim Elbląg, lokowany w roku 1236, zaledwie trzy lata po Toruniu, i w mniejszym stopniu konkurencyjne początkowo Braniewo; choć we wczesnym okresie rozwoju oba miasta miały duże znaczenie, Braniewo stopniowo je utraciło. Dalej na północ znajdował się Królewiec, o dziewiętnaście lat młodszy od Elbląga, ważny ośrodek administracyjny Sambii oraz port handlowy u ujścia Pregoły; ze względu na korzystne położenie, pełnił ważną funkcję w eksporcie płodów rolnych, ale także surowca bursztynowego. Miasto nad Pregołą - wraz z tutejszym rozległym zamkiem konwentualnym - miało przy tym trudny do przecenienia udział w przygotowywaniu wypraw krzyżowych w kierunku litewskim; komtur królewiecki był zarazem wielkim marszałkiem Zakonu, organizującym akcje militarne, jednym z pięciu tzw. wielkich dostojników. Królewiec był także siedzibą jednego z czterech biskupstw pruskich (co ciekawe, pozostali biskupi swoje katedry mieli w stosunkowo mało znaczących miastach: Chełmży, Kwidzynie, Fromborku). Miasto nad Pregołą, ze względu na korzystne położenie, pełniło ważną funkcję handlową dla eksportu płodów rolnych ale także surowca bursztynowego. Jednak najważniejszym centrum handlowo-rzemieślniczym w państwie zakonnym stał się - począwszy od zaboru w 1308-1309 roku całego księstwa wschodniopomorskiego - Gdańsk; dominującą pozycję osiągnął w ciągu drugiej połowy XIV wieku².

2 Karol Górski, Zakon krzyżacki a powstanie państwa pruskiego (wyd. I - Wrocław: Ossolineum 1977; wyd. II - Bydgoszcz: Excalibur, Malbork: Muzeum Zamkowe, 2003), 47-50; Marian Biskup i Gerard Labuda, Dzieje zakonu krzyżackiego w Prusach. Gospodarka - społeczeństwo 
We wszystkich wymienionych miastach, zwanych wielkimi miastami pruskimi $^{3}$, funkcjonowało rzemiosło złotnicze. Dynamika wielkości produkcji, intensywności działań artystycznych, zainteresowania zleceniodawców, powiązanie z rynkiem zbytu towarów masowych (zboże, drewno) i wyrobów luksusowych, były różne w poszczególnych okresach historycznych. Najwcześniej ta dynamika przejawiła się w Toruniu, nie tylko z powodu wysunięcia się tego ośrodka na centrum polityczno-administracyjno-militarne tworzonego w XIII wieku państwa zakonu krzyżackiego, ale także - co dla omawianego zagadnienia szczególnie ważne, lecz dla procesu rozwoju ekonomicznego typowe - dzięki funkcjonowaniu mennicy: złotnicy byli tymi specjalistami, którzy potrafili wycinać godła w stemplach menniczych, zatem kompetentnymi do wykonywania czynności mincerza ${ }^{4}$.

- państwo - ideologia (Gdańsk: Wydawnictwo Morskie, 1988); Janusz Tandecki, Średniowieczne księgi wielkich miast pruskich jako źródła historyczne i zabytki kultury mieszczańskiej (Warszawa-Toruń: IS PAN, 1990), 11-14; Roman Czaja, Miasta pruskie a zakon krzyżacki. Studia nad stosunkami między miastem a władzą terytorialna w późnym średniowieczu (Toruń: Wydawnictwo UMK, 1999); Roman Czaja, „Urbanizacja kraju”, w Państwo zakonu krzyżackiego w Prusach. Władza i społeczeństwo, red. Marian Biskup i Roman Czaja (Warszawa: PWN, 2009), 177-199; Roman Czaja, „Miasta i przestrzeń miejska w państwie zakonu krzyżackiego w Prusach”, w Zakon krzyżacki w Prusach i Inflantach. Podziały administracyjne i kościelne w XIII-XVI wieku, red. Roman Czaja i Andrzej Radzimiński (Toruń: Wydawnictwo Naukowe UMK, 2013), 81-106.

3 Do grupy wielkich miast nie należały całe aglomeracje miejskie, lecz konkretne jednostki; obok „pojedynczych” miast Chełmna i Braniewa były to: Stare Miasto Toruń, Stare Miasto Elbląg, Stare Miasto Królewiec, Główne (Prawe) Miasto Gdańsk; do Hanzy mogły należeć także inne człony miejskie, np. Knipawa w Królewcu.

4 Wzmianki o złotnikach w Toruniu pochodzą już z XIII i 1. połowy XIV w., w 2. połowie XIV i na początku XV w. są już liczne; w 1408 r. jest wymieniony z imienia złotnik Pawel, przybyły do mennicy z Inflant, oraz złotnik i mincerz („monczmeister”, „us der moncze”) Claws, który wykonał dla wielkiego mistrza 11 dużych srebrnych i złoconych pucharów; zob. Eugen von Czihak, Die Edelschmiedekunst früherer Zeiten in Preussen, t. 2 Westpreussen (Leipzig: Verlag von Karl W. Hiersmann, 1908), 121; Tomasz Jasiński, „Rozwój złotnictwa toruńskiego do końca XV w.", Acta Universitatis Nicolai Copernici. Historia 11 (1977): 40-44. Problematyczny jest początkowy okres funkcjonowania mennicy w Toruniu; wprawdzie przywilej chełmiński mówi wyraźnie o jednolitej monecie, a dokument z 1238 r. wymienia denar toruński jako monetę pruską, jednak aż do lat 80. XIV w. brak źródeł pisanych dotyczących nie tylko czasu powstania mennicy, ale i jej funkcjonowania, co mocno podkreśla ostatnia monografistka tej instytucji Żaneta Bonczkowska, Mennica toruńska od drugiej połowy XIV wieku do 1454 roku. Lokalizacja - personel - funkcjonowanie (Toruń: Wydawnictwo Adam Marszałek, 2011), 23-25, 35-37, 187. Niepewny jest także czas powstania mennic elbląskiej i królewieckiej, choć można przyjąć, że funkcjonowały już w 2. połowie XIII w.; znacznie później, dopiero od końca XIV w. działała mennica w Gdańsku, a malborska jest z nich najpóźniejsza, Bonczkowska, Mennica toruńska, 23-28. 
Cechy złotnicze jako wyspecjalizowane korporacje skupiające jedynie przedstawicieli profesji złotniczej były w Prusach zakładane począwszy od drugiej połowy XIV wieku. Na przykład w Gdańsku zrzeszenie złotników powstało w latach siedemdziesiątych (ale przed rokiem 1378), w Elblągu najpóźniej w 1385 roku, w Toruniu - po dłuższym okresie przynależności wraz z konwisarzami i szklarzami do cechu łączonego - jako samodzielna organizacja najpóźniej w 1476 roku, w Malborku w połowie XV wieku, w Braniewie zapewne tuż przed rokiem 1470, w Królewcu być może w końcu XIV stulecia, choć pierwsze statuty (Gewerksrolle) pochodzą dopiero z 1515 roku $^{5}$. Druga połowa XIV wieku była zarazem czasem prosperity ekonomicznej państwa, stabilizacji struktur politycznych i ekonomicznych, a także niebywałego rozkwitu sztuk plastycznych - w stosunkowo krótkim czasie region pozbawiony tradycji warsztatowych i rodzimego wykonawstwa stał się przestrzenią nasyconą wyrobami miejscowych artystów. Proces ten, o dynamice rozwoju widocznej przede wszystkim w zakresie monumentalnej rzeźby pełnoplastycznej ${ }^{6}$, przebiegał w ślad za szczególnie intensywnym rozwojem architektury - zarówno kościelnej, jak i zamkowej, na potrzeby Zakonu, biskupstw (biskupów), miast i parafii ${ }^{7}$.

We wcześniejszej fazie rozwoju ekonomicznego miast złotnicy byli czynni jeśli nie poza strukturą cechową, to z pewnością - przed powstaniem wyspecjalizowanych korporacji branży złotniczej - w cechach zbiorczych. Niewątpliwie pracowali na zamówienie komturstw, a po ustabilizowaniu struktury administracyjnej państwa zakonnego także tzw. wielkich dostoj-

5 Czihak, Die Edelschmiedekunst, 1, 5, 121-122, 147, 175; odnośnie do mniejszych ośrodków na Pomorzu w czasach nowożytnych zob. Jacek Kriegseisen, „Złotnicy w małych miastach województwa pomorskiego od połowy XVI do końca trzeciej ćwierci XVIII wieku”, w Klejnot w koronie Rzeczypospolitej. Sztuka zdobnicza Prus Królewskich, t. 1 Eseje, red. Czesława Betlejewska (Gdańsk: Muzeum Narodowe, 2006), 80-84.

6 Carl-Heinz Clasen, Die mittelalterliche Bildhauerkunst im Deutschordensland Preussen. Die Bildwerke bis zur Mitte des 15. Jahrhunderts, t. 1-2 (Berlin: Deutscher Verein für Kunstwissenschaft, 1939); Tadeusz Jurkowlaniec, Gotycka rzeźba architektoniczna w Prusach (Studia z Historii Sztuki, t. 42, red. Jerzy Kowalczyk et al.) (Wrocław-Warszawa-Kraków-Gdańsk-Łódź: Ossolineum, 1989) i szereg późniejszych szczegółowych rozpraw tego autora; zob. też teksty Anny Błażejewskiej i Andrzeja Wozińskiego w tomie Fundacje artystyczne na terenie państwa zakonnego w Prusach, t. 2 Eseje, red. Barbara Pospieszna (Malbork: Muzeum Zamkowe, 2010), 166-194, 195-212.

7 Istnieje bogata literatura tematu, zob. m.in. teksty Mariana Arszyńskiego, Liliany Krantz-Domasłowskiej, Christophera Herrmanna w Fundacje artystyczne, t. 2, 7-45, 46-66, 67-84; Tomasz Torbus, Zamki konwentualne państwa krzyżackiego w Prusach (Gdańsk: Wydawnictwo słowo/obraz terytoria, 2014). 
ników zakonnych: poza wielkim mistrzem zwłaszcza wielkiego komtura (rezydującego również w Malborku) i wielkiego marszałka, zarazem komtura w Królewcu. Zlecenia kościelne w dużej części były tożsame z krzyżackimi ${ }^{8}$. Poza warmińskim trzej biskupi pruscy - chełmiński, pomezański i sambijski, a także członkowie kapituł katedralnych i proboszczowie ważniejszych parafii miejskich należeli do Zakonu jako bracia-kapłani; nieco inne stosunki panowały na Pomorzu Gdańskim, które wchodziło w skład diecezji włocławskiej (kujawsko-pomorskiej), choć i tam najważniejsze stanowiska obsadzano księżmi krzyżackimi ${ }^{9}$.

Najstarsze znane i zachowane dzieła osadzone w historii Prus pochodzą z około 1300 roku. W większości są to pojedyncze gładkie kielichy, niczym się niewyróżniające ${ }^{10}$. Należą do nich także skromne cyboria eucharystyczne, wykonane dopiero w XIV stuleciu ${ }^{11}$, lecz półkulistą czaszą z pokrywą, dającą formę spłaszczonej nieco i przewężonej kuli, nawiązują do dwunastoi trzynastowiecznych cyboriów. Wyróżnia się kielich ze Starego Targu - dość tradycyjny, o cechach późnoromańskich z nieznacznymi akcentami wczesnogotyckimi, w stylu reliefowych medalionów z wyobrażeniem Ukrzyżowania ${ }^{12}$. (il. 1) Takie preferencje stylowe nie były w owym czasie niczym odosobnionym w szeroko rozumianej Europie środkowej, np. w Saksonii ${ }^{13}$; jednocze-

8 W publikacji prezentującej skądinąd imponującą wystawę Fundacje artystyczne na terenie państwa zakonnego $w$ Prusach, t. 1 Katalog wystawy, red. Barbara Pospieszna (Malbork: Muzeum Zamkowe, 2010) trochę sztucznie podzielono zamówienia i zlecenia artystyczne dokonywane na tym terenie na fundacje zakonne, kościelne i miejskie: pozycja np. proboszczów far wielkich miast pruskich była swoista zarówno w kontekście zakonnym, kościelno-administracyjnym, jak i społecznym, a w związku z tym trudna - wręcz niemożliwa - do jednoznacznego ujęcia w przyjętym podziale; kwestia ta wymaga zatem ostrożności i dodatkowych bardziej precyzyjnych stratyfikacji.

$9 \quad$ Wywód na temat zleceń w zakresie złotnictwa na terenie państwa zakonu krzyżackiego opiera się w części na moich wcześniejszych ustaleniach i propozycjach, zob. Michał [F.] Woźniak, „Die Goldschmiedekunst in Preussen im Dienste des Ordens, der Kirche und der Städte”, w Mittelaterliche Kultur und Literatur im Deutschordensstaat in Preussen: Leben und Nachleben, red. Jarosław Wenta, Siegelinde Hartmann i Gisela Vollman-Profe (Sacra Bella Septentrionalia, t. 1) (Toruń: Wydawnictwo Naukowe UMK, 2008), 125-156.

10 Szczepkowska-Naliwajek, Złotnictwo gotyckie, 46-52.

11 Szczepkowska-Naliwajek, Złotnictwo gotyckie, 52-53; do wspomnianego przez tę badaczkę cyborium z Barłożna doliczyć należy nieznane jej cyboria warmińskie, przechowywane obecnie w konkatedrze św. Jakuba w Olsztynie, zob. Małgorzata Okulicz, Złotnictwo sakralne dominium warmińskiego od połowy XIV do końca XVIII wieku. Katalog wystawy (Olsztyn: Muzeum Warmii i Mazur, 2006), 44-47.

12 Szczepkowska-Naliwajek, Złotnictwo gotyckie, 47-49.

13 Obszerny materiał, w dużej części dotąd nieznany lub słabo rozpoznany, został ujawniony podczas przygotowywania wystawy złotnictwa kościelnego z obszaru saskiej prowincji Ko- 
śnie kielich zdradza wyraźne pokrewieństwa ze złotnictwem Górnej Nadrenii ostatniej ćwierci XIII wieku. Dzieło to pozwala zarazem na sformułowanie dwóch pierwszych problemów badawczych istotnych dla starszej wytwórczości złotniczej w Prusach. Jednym jest dobrze uchwytne podobieństwo do form stosowanych w Nadrenii (także Dolnej), o czym przekonują wspomniane skromne kielichy. Bliskie współzależności z tymi regionami artystycznymi, do których przyjdzie dodać także sąsiednią Westfalię, dają o sobie znać nie tylko w Prusach Zakonnych. Przetrwały one po zakończeniu wojny trzynastoletniej również w Prusach Królewskich, zachodniej części państwa krzyżackiego, która na mocy drugiego traktatu toruńskiego z 1466 roku przyłączona została do Królestwa Polskiego, i widoczne są w dziełach noszących cechy stylu późnogotyckiego powstałych w początkach, a nawet całej pierwszej ćwierci XVI wieku ${ }^{14}$. Drugie zagadnienie dotyczy roli importów w wytwórczości pruskiej - importów zarówno dzieł, jak i artystów, ich sprowadzania z głębi Rzeszy do coraz bardziej ustabilizowanego wewnętrznie państwa, sprawnie zarządzanego, o wzrastającej pozycji polityczno-militarnej i postępującej za nią w ślad ekonomicznej. Podobne pytania stawiają autorzy badań poświęconych rzeźbie monumentalnej i malarstwu, aczkolwiek z inną chronologią dzieł i z odmienną geografią owych importów, czyli zewnętrznych kręgów odniesienia. W tych obszarach aktywności artystycznej dostrzegane są i podkreślane relacje turyńsko-heskie i czeskie ${ }^{15}$. W złotnictwie owych czeskich wątków i inspiracji jest niewiele (aczkolwiek dają się zauważyć w kilku znaczących dziełach z około 1400 roku $^{16}$ ), silne zaś są nadreńskie.

ścioła ewangelickiego, zob. Goldschmiedekunst des Mittelalters. Im Gebrauch der Gemeinden über Jahrhunderte bewahrt, red. Bettina Seyderhelm (Magdeburg: Evangelische Kirche der Kirchenprovinz Sachsen, Kirchliche Stiftung Kunst- und Kulturgut in der Kirchenprovinz Sachsen, 2001), 175-189, 196-209, 212-245.

14 Szczepkowska-Naliwajek, Złotnictwo gotyckie, passim; Michał F. Woźniak, Złotnictwo sakralne Prus Królewskich. Studium typologiczno-morfologiczne (Toruń: Wydawnictwo Naukowe UMK, 2012), 29.

15 Spośród ostatnich publikacji zob. Monika Jakubek-Raczkowska, „Sztuka w państwie zakonnym w Prusach w latach 1309-1410. Panorama zjawisk w przededniu tzw. wielkiej wojny”, w Conflictus magnus apud Grunwald 1410. Między historia a tradycją, red. Krzysztof Ożóg i Janusz Trupinda (Malbork: Muzeum Zamkowe, 2013), 39-64; Juliusz Raczkowski, Monumentalne zespoły kolegium apostolskiego na terenie dawnego państwa zakonnego w Prusach (Pelplin: Wydawnictwo Bernardinum, 2013), 157-184.

16 Wśród nich poczesne miejsce zajmują grawerunki na puszce - naczyniu na rezerwę eucharystyczną z Chojnic, ok. 1400-1410 - zob. Fritz, Goldschmiedekunst der Gotik, 265-266; Szczepkowska-Naliwajek, Złotnictwo gotyckie, 99-100, 129-130, 183-184; Michał F. Woźniak, „Cyborium eucharystyczne”, w Imagines potestatis. Insygnia i znaki władzy w Królestwie Polskim i Zakonie Niemieckim, red. Janusz Trupinda (Malbork: Muzeum Zamkowe - Byd- 
Oba te zasadnicze dla badań nad złotnictwem wczesnego okresu problemy skupiają się jak w soczewce w jednym dziele, przy tym klasy wybitnej: dyptyku relikwiarzowym komtura zamkowego elbląskiego Filipa (Thiele) von Lorich, sprawionym - według inskrypcji tworzącej bordiurę rewersu - w 1388 roku $^{17}$. (il. 2, 3) Fundator pochodził z kręgów rycerstwa nadreńsko-lotaryńskiego, które - obok południowoniemieckiego - stanowiło w tym czasie podstawową siłę napędzającą Zakon: z tych regionów przede wszystkim rekrutowali się zakonni bracia. O podobnych relikwiarzach w kształcie tablicy (tofil) wspominają źródła zakonne, czyli inwentarze kościołów zamkowych (konwentualnych $)^{18}$. Przechowywane zwykle w zakrystiach, były one uroczyście noszone w procesjach, okazyjnie, podczas świąt stawiane na ołtarzach, wenerowane bezpośrednio, wizualnie i pocałunkiem - co umożliwiało zamknięcie partykuł w przeszklonych przegrodach. W dyptyku elbląskim przegrody z relikwiami obiegają wewnętrzne, plastyczne przedstawienia: Ukrzyżowania oraz Adoracji Matki Bożej z Dzieciątkiem przez fundatora w towarzystwie szeregu świętych. Rewersy obu skrzydeł ukazują grawerowane wyobrażenia Vir dolorum z licznymi arma christi oraz ponownie Adorację Dzieciątka na kolanach Marii przez rycerza, z towarzyszącą św. Barbarą. Źródła, zwłaszcza księga rachunkowa podskarbiego zakonnego (Tressler) zachowana we fragmencie obejmującym lata 1399-1409, wymieniają miejscowych artystów, w tym złotników: czynnego najprawdopodobniej w Malborku Jakuba oraz kilkakrotnie Wilhelma (Wilama) z Elbląga, wielokrotnie zatrudnianego przez wielkiego mistrza i wielkiego komtura do wykonywania licznych prac - spo-

goszcz: Markgrafsen, 2007), 448-450; także dekoracja współczesnego lub nieco tylko późniejszego krzyża relikwiarzowego z Tczewa - zob. Fritz, Goldschmiedekunst der Gotik, 266; Szczepkowska-Naliwajek, Złotnictwo gotyckie, 97-102, 240-241.

17 Fritz, Goldschmiedekunst der Gotik, 229-230; Michał [F.] Woźniak, „Das Reliquiendiptychon des Elbinger Hauskomturs Thilo von Lorich“, Anzeiger des Germanischen Nationalmuseums (1992): 51-62; Michał [F.] Woźniak, „Dyptyk relikwiarzowy elbląskiego komtura domowego Thiele von Loricha“, w Praeterita posteritati. Studia z historii sztuki i kultury ofiarowane Maciejowi Kilarskiemu, red. Mariusz Mierzwiński (Malbork: Muzeum Zamkowe, 2001), 481-500 - w moich obu pracach, nieznacznie się różniących, referowana cała starsza literatura i poglądy badawcze; ponadto Mieczysław Siciński i Janusz Trupinda, „Relikwiarz gotycki komtura Thilo von Lorich”, w Imagines potestatis, 443-445; Wojciech Krajewski, „Relikwiarz”, w Na znak świetnego zwycięstwa. W sześćsetna rocznicę bitwy pod Grunwaldem, red. Dariusz Nowacki, t. 2 (Kraków: Zamek Królewski na Wawelu, 2010), 145-148.

18 Michał F. Woźniak, „Art and Liturgy in Teutonic Castle Churches”, w Sacred Space in the State of the Teutonic Order in Prussia, red. Jarosław Wenta (Sacra Bella Septentrionalia, t. 2) (Toruń: Wydawnictwo Naukowe UMK, 2013), 159-160. 
rządzania nowych naczyń lub reperowania używanych sprzętów ${ }^{19}$. Opierając się na tym przykładzie można sformułować tezę o osiągniętym w drugiej połowie XIV wieku wysokim poziomie lokalnego wykonawstwa. Przemawia za tym - co warte podkreślenia - zlecanie przez najwyższych dostojników prac u miejscowych złotników, wobec stosunkowo mało skomplikowanej możliwości sprowadzania dzieł złotniczych z odleglejszych ośrodków; sprzyjała temu chociażby rozbudowana sieć kontaktów zagranicznych Zakonu - kościelnych, politycznych, militarnych, gospodarczych. Dodatkowym czynnikiem ułatwiającym porównanie jakości i jej ocenę była niewątpliwie obecność na zamkach krzyżackich obcych dzieł, na przykład w postaci darów dla wielkiego mistrza i wielkiego marszałka (poświadczonych źródłowo dla Królewca) składanych przez rycerzy gości, w tym wielu z kręgów arystokracji, przybywających do Prus dla odbycia wyprawy krucjatowej na Litwę (wówczas już stopniowo chrystianizowaną, co nie przeszkadzało w zachowaniu pozorów i służyło podtrzymaniu słabnącego etosu europejskiego rycerstwa). Te wskaźniki pośrednie, a zarazem samoświadomość wysokiej kultury dworskiej w Zakonie u schyłku XIV wieku, mogą prowadzić do wniosku o dużym udziale miejscowych artystów w zaspokajaniu potrzeb zakonnych zleceniodawców (a Zakon był przecież zbiorowym panem feudalnym w Prusach). Do takiej konkluzji skłaniać też może porównanie z wieloma wysokiej klasy dziełami malarstwa i rzeźby pochodzącymi z pruskich warsztatów (co oczywiście nie wyklucza importów, np. kutych w wapieniu figur pięknych madonn i „pięknych” Piet, $\mathrm{z}$ których te najważniejsze zapewne w $\left.\operatorname{Pradze}^{20}\right)$. Pewne elementy niderlandyzujące w stylu figurek (zwłaszcza grupy Ukrzyżowania) w owym dyptyku ${ }^{21}$ nie mogą zaskakiwać: znane są żywe relacje handlowe Zakonu z Flandrią (zwłaszcza z Brugią, dokąd eksportowano także bałtycki bursztyn) i szerzej z ziemiami pod władzą książąt burgundzkich. Przekonuje o tym także obec-

19 Michał [F.] Woźniak, „Wystrój i wyposażenie zamku malborskiego w świetle rachunków i inwentarzy”, Studia Zamkowe 2 (2006): 62, 64-65.

20 Monika Jakubek-Raczkowska, Rzeźba gdańska przełomu XIV i XV wieku (Warszawa: Wydawnictwo DiG, 2006); Monika Jakubek-Raczkowska, „Die Einflüße Böhmens auf die gotische Skulptur im Ordensland Preussen. Ein Überblick im Lichte der neuesten Forschungen“, w Kunst als Herrschaftsinstrument. Böhmen und das Heilige Römische Reich unter den Luxemburgern im europäischen Kontext, red. Jiři Fajt i Andrea Langer (München-Berlin: Deutscher Kunstverlag, 2009), 550-563.

${ }^{21}$ Gerhard Schmidt, „Zu einem Buch über den Meister der Schönen Madonnen“, Zeitschrift für Kunstgeschichte 41 (1978): 86; przedruk w: Gerhard Schmidt, Gotische Bildwerke und ihre Meister (Wien-Köln-Weimar: Böhlau Verlag, 1992), 260. 
ność w Gdańsku w latach 1403-1405 rzeźbiarza Jana van der Matten (Jean de la Matte), uprzednio czynnego w Brugii.

Monstrancja z poznańskiego kościoła Karmelitów pw. Bożego Ciała wprowadza w odmienną problematykę $e^{22}$. (il. 4a) Jej forma zdradza wyraźne pokrewieństwa z dziełami nadreńskimi (dolnoreńskimi). Monstrancja ta wyróżnia się wysoką jakością artystyczną, równowagą architektonicznej konstrukcji i dekoracji, powściągliwością i dużą dyscypliną w zakresie formy - ma rozbudowaną kompozycję ze zdecydowanym członowaniem bez popadania w drobiazgowość. Jej stosunkowo urozmaicona bryła zachowuje nadrzędną czytelność; jako szczególny przykład takiej postawy można wskazać ukształtowanie górnej partii wieży, powyżej cylindrycznego reservaculum, z ażurowym rdzeniem opiętym systemem przypór i łuków odporowych. Znaczenie tego wybitnego dzieła dodatkowo zasadza się na nie do końca poświadczonym związku z królem Władysławem Jagiełłą. Był on w 1406 roku fundatorem klasztoru i kościoła Karmelitów na przedmieściu Poznania, w miejscu wcześniejszego o siedem lat cudu eucharystycznego ${ }^{23}$. Na osobę monarchy wskazują herby umieszczone na stopie, jednak niewątpliwe wtórnie, o czym świadczy gorsza jakość ich wykonania i niedopasowanie do krzywizny płaszcza stopy. Równie niewątpliwe zdaje się pruskie pochodzenie dzieła ${ }^{24}$. Wielokrotnie dyskutowane było w literaturze zagadnienie proweniencji monstrancji: Czy została wykonana na polskie zlecenie, złożone w którymś z pruskich warsztatów (torunskim, gdańskim; na to drugie środowisko wskazywałaby późniejsza o około ćwierci wieku monstrancja z Chojnic ${ }^{25}$ ), a następnie uzupełniona o owe herby przez złotnika pracującego w Królestwie (w Poznaniu, może w Krakowie)? Czy też należała do łupów zdobytych przez polskie wojska podczas kampanii

22 Wielokrotnie publikowana, zob. m.in. Fritz, Goldschmiedekunst der Gotik, 265; Szczepkowska-Naliwajek, Złotnictwo gotyckie, 117-119, 229-230; Zygmunt Dolczewski i Renata Sobczak-Jaskulska, „Monstrancja Jagiełłowa z kościoła Bożego Ciała w Poznaniu”, Kronika Miasta Poznania 68, nr 1 (2000): 36-42; Michał [F.] Woźniak, „Monstrancja eucharystyczna”, w Imagines potestatis, 438-440; Marek Walczak, „Monstrancja”, w Na znak świetnego zwycięstwa, 159-163; we wszystkich tych publikacjach wyczerpujące wskazówki bibliograficzne.

23 Zofia Kurzawa, „Monstrancje-relikwiarze w kościele Bożego Ciała w Poznaniu”, Kronika Miasta Poznania 60, nr 3-4 (1992): 169-170; por. też inne artykuły w tym monograficznym numerze czasopisma.

24 Dolczewski i Sobczak-Jaskulska, „Monstrancja Jagiełłowa”, 39, sugerują także możliwość sprowadzenia monstrancji z Dolnej Saksonii, Westfalii lub Holandii, bez wskazania konkretnego ośrodka złotniczego.

25 Fritz, Goldschmiedekunst der Gotik, 265; Szczepkowska-Naliwajek, Złotnictwo gotyckie, 117-120, 184 - badaczka stawia monstrancję chojnicką wyżej niż poznańską. 
wojennej 1410 roku i została podarowana przez króla do Poznania, do jednej z jego ulubionych fundacji (wiadomo, że zdobycznymi szatami i sprzętami liturgicznymi król obdarował wiele ważniejszych kościołów w Koronie i na Litwie)? W ten sposób można by wyjaśnić zagadkową obecność figurki św. Bartłomieja w górnej kondygnacji wieży: może sugerować osobistego patrona fundatora bądź szczególnie przez niego wenerowanego świętego lub mieć związek z patrocinium kościoła, do którego monstrancja była pierwotnie przeznaczona; brak jednak konkretnych przesłanek za konfirmacją takiej hipotezy. Poza przypuszczeniami sformułowanymi w dotychczasowej literaturze jawi się jeszcze jedna możliwość. Wiadomo, że kościołowi Bożego Ciała przekazano pewne kwoty z kasy Tresslera (na podobieństwo jałmużniczych darów, jakie otrzymywały wybrane kościoły mendykanckie na terenie państwa zakonnego) - może więc któryś z krzyżackich dostojników sprawił tę monstrancję w czasach gdy rywalizacja polsko-krzyżacka narastała, ale sporo jeszcze brakowało do stanu otwartego konfliktu zbrojnego i starano się utrzymywać poprawne stosunki?

Znacznie częściej jako przykład okazałych monstrancji pruskiej roboty (pruskich ostensoriów) wymieniana jest monstrancja z kościoła pw. Ścięcia św. Jana Chrzciciela w Chojnicach (w tymże kościele znajduje się także wcześniejsza, a współczesna monstrancji poznańskiej, puszka na komunikanty ze znakomitymi grawerunkami na ściankach oraz nieco młodszy od chojnickiej krzyż relikwiarzowy ${ }^{26}$.Jest ona większa, bardziej rozbudowana i bogaciej członowana, zgodnie z tendencją rozwojową monstrancji wieżowych w pierwszej połowie XV wieku. Jednak bezpośrednia obserwacja prowadzi do wniosku, że staranniej wykonana, bardziej logicznie i konsekwentnie zbudowana, w detalach nierównie precyzyjniej cięta jest właśnie monstrancja poznańska - zarazem najstarsze tego typu naczynie eucharystyczne w całym regionie prusko-polskim. Nodus monstrancji z Poznania (il. 4b), zbudowany z przenikających się brył - spłaszczonej kuli, graniastej obręczy i kasztowych opraw osadzonych tam kamieni - swą precyzją, a przy tym zniewalającą prostotą budowy i nadrzędnością efektu konstrukcyjnego żywo przypomina ukształtowanie detali rozbudowanej w ostatnim dziesiątku lat XIV wieku zachodniej partii Pałacu Wielkich Mistrzów w Malborku, zwłaszcza portalu prowadzącego do tzw. Letniego Refektarza. Rozpoznaję w obydwu dziełach wielkiej i małej -

26 Szczepkowska-Naliwajek, Złotnictwo gotyckie, 99-105, 183-185; zob. też przyp. 16; dzieła chojnickie czasowo bywają eksponowane w Muzeum Diecezjalnym w Pelplinie. 
tj. monumentalnej i miniaturowej - architektury podobny sposób planowania i konstruowania bryły oraz struktury przestrzennej.

Powstałe w ciągu XV po początek XVI wieku liczne kielichy pozwalają ze względu na ową znaczącą kwantytatywność - na ciekawe i przekonujące obserwacje. Nie zrezygnowano w nich z charakterystycznej także dla Dolnej Nadrenii i sąsiednich prowincji - czyli Górnej Nadrenii, Westfalii i północnych Niderlandów - dodatkowej obręczy (przewiązki) pomiędzy stopą a trzonem, zbudowanej z detali architektonicznego pochodzenia, ale przede wszystkim ze stosunkowo płytkiej i mocno konicznie rozwartej czaszy, przypominającej zarówno dzieła wczesnogotyckie, jak i tradycję nadreńską; na tym jedynie obszarze bardzo długo, aż po kres wytwórczości o cechach późnogotyckich, przetrwały czasze podobnego kształtu. Złotnicy czynni w Prusach opracowali własny zespół elementów konstytuujących charakterystyczny dla regionu pruskiego kształt, z odmiennymi też proporcjami, kontrastująco odrębny w zestawieniu z wyrobami pochodzącymi z sąsiednich środkowoeuropejskich ośrodków wytwórczych. Składa się nań - na ten zestaw odrębności - wyrazistość graniastej budowy, urozmaicona jednak delikatną dekoracją, łagodzącą wyjściową ostrość, oraz równowaga dekoracji, zarówno grawerowanej (płaskiej, linearnej), jak i odlewanej (plastycznej, reliefowej), a także częste stosowanie kapliczkowego nodusa. (il. 5.6)

Pomimo zmiany przynależności politycznej zachodnich ziem państwa zakonu krzyżackiego, w wyniku traktatu toruńskiego z 1466 roku przyłączonych lub ponownie włączonych do Królestwa Polskiego, zachowano ciągłość kształtowania formy naczyń. Ponadto, pomijając pewne drobne zróżnicowania i pojedyncze cechy, raczej podrzędne, trudno byłoby się doszukać cech swoistych dla poszczególnych ośrodków złotniczych. Dzieła, które na podstawie kryterium topograficznego lub prozopograficznego można wiązać z poszczególnymi centrami artystycznymi, także złotniczymi (zwłaszcza Gdańskiem, Elblągiem i Toruniem), charakteryzują się daleko posuniętym ujednoliceniem formy i dekoracji. Podstawowym argumentem atrybucyjnym staje się pochodzenie zabytków, a ściślej mówiąc pierwotne ich przeznaczenie, ich dawna lokalizacja, poświadczona obecność w jednym z kościołów (albo innych instytucji) tych trzech miast względnie w bezpośredniej ich bliskości lub też w strefie ich wpływów ekonomicznych. O odrębności bądź swoistości Braniewa i Królewca trudno wnioskować z powodu skąpego materiału zabytkowego. Ranga Królewca wzrośnie niebywale w ciągu XVI wieku, już w czasach odrębności wschodniej części Prus - zrazu jeszcze, po 
roku 1466, jako państwa zakonnego - zwłaszcza po 1525 roku, po utworzeniu Księstwa Pruskiego.

Książę Albrecht Hohenzollern (Albrecht Pruski, Markgraf von Brandenburg-Ansbach ${ }^{27}$, od 1511 roku wielki mistrz zakonu krzyżackiego, po nieudanych (politycznych i militarnych) próbach uzyskania przez państwo zakonne niezależności i dawnego znaczenia wraz z uprzednim terytorium, dokonał radykalnego zwrotu. Za zgodą swojego wuja Zygmunta Starego przekształcił Prusy w świeckie księstwo (będące nadal lennem Polski), zarazem zrywając z Kościołem rzymskim (katolickim), przyjmując wyznanie luterańskie i tworząc pierwsze protestanckie państwo w Europie. Królewiec - jedno z kilku wielkich miast pruskich - stał się już po 1466 roku jedynym dużym ośrodkiem miejskim w Prusach zakonnych, a następnie w księstwie. Albrecht uczynił $\mathrm{z}$ niego miasto rezydencjonalne, wyposażając w niezbędne atrybuty i instytucje ${ }^{28}$. Należał do nich nie tylko przebudowany w nowym stylu zamek, wspaniałe nagrobki (epitafium pierwszej żony Doroty duńskiej i nagrobek księcia zamówiony w roku jego śmierci, czyli 1568, przez radę stanu w imieniu następcy Albrechta II Fryderyka - dzieła antwerpskiego rzeźbiarza, architekta i projektanta Cornelisa Florisa, nagrobek ks. Elżbiety von Brandenburg-Küstrin, żony regenta Jerzego Fryderyka, wykonany w latach 1578-1682 przez ucznia Florisa Willema van den Blocke, czynnego później w Gdańsku) w prezbiterium katedry ${ }^{29}$, liczny dwór, arystokratyczne rozrywki, ale także

27 Walther Hubatsch, Albrecht von Brandenburg-Ansbach. Deutschordens-Hochmeister und Herzog in Preußen 1490-1568 (Studien zur Geschichte Preußens, t. 8) (Heidelberg: Quelle \& Meyer, 1960; Janusz Małłek, Dwie części Prus. Studia z dziejów Prus Książęcych i Prus Królewskich w XVI i XVII wieku (Olsztyn: Wydawnictwo Pojezierze, 1987; wyd. II - Toruń: Wydawnictwo Naukowe UMK, 2015); Janusz Małłek, Prusy Książęce a Prusy Królewskie w latach 1525-1548. Studium z dziejów polskiej polityki księcia Albrechta Hohenzollerna (Warszawa: PWN, 1976; wyd. II - Toruń: Wydawnictwo Naukowe UMK, 2016).

28 Janusz Jasiński, Historia Królewca. Szkice z XIII-XX stulecia (Olsztyn: Książnica Polska, 1994), 34-55; Janusz Małłek, „Königsberg - von der Hauptstadt des Deutschen Ordens zur Residenz und Hauptstadt des Herzogtum Preußen“, w Metropolen im Wandel. Zentralität in Ostmitteleuropa an der Wende vom Mittelalter zur Neuzeit, red. Evamaria Engel, Karen Lambrecht i Hanna Nogossek (Berlin: Akademie Verlag, 1995), 127-133; wersja polska: „Królewiec na drodze przemian od stolicy państwa zakonu krzyżackiego do stolicy Księstwa Pruskiego i rezydencji książęcej”, w Studia nad dziejami miast i mieszczaństwa w średniowieczu. Studia ofiarowane Profesorowi Antoniemu Czacharowskiemu, red. Roman Czaja i Janusz Tandecki (Toruń: Wydawnictwo UMK, 1996), 113-119.

29 Franciszek Skibiński, Willem van den Blocke. Niderlandzki rzeźbiarz nad Bałtykiem w XVI i na początku XVII w. (Toruń: TNT, 2015), 45-54, 133-138, 195-209. 
uniwersytet założony w 1544 roku i biblioteki: publiczna, służąca uniwersytetowi, zwana Bibliotheca Nova, oraz prywatna - Kammerbibliothek ${ }^{30}$.

Książę wspierał twórczość artystyczną, sprowadzał dzieła sztuki oraz artystów. Był zdeklarowanym luteraninem, korespondował na tematy polityczne, militarne, teologiczne i wyznaniowe, artystyczne; odbiorcami jego listów byli także polscy możnowładcy i humaniści w Rzeszy. Dążył - z sukcesem do powstrzymania eksportu bursztynu pozyskiwanego na wybrzeżu Sambii. Wprawdzie większość tego surowca nadal trafiała do Gdańska, ale największe i najcenniejsze bryły pozostawały w kraju i lokalni bursztynnicy używali ich do wyrobu luksusowych przedmiotów - dzbanów, pucharów, pater, kufli, traktowanych jako składnik książęcego przepychu i reprezentacji, przeznaczanych też na prezenty dyplomatyczne ${ }^{31}$. Owe bursztynowe naczynia były często oprawiane w srebro, choćby dla stabilizacji kruchej bryły, a ich wyszlifowane cienkie ścianki dawały olśniewające efekty przeświecania w różnych odcieniach złocistej barwy. Były cenione zarówno jako kosztowne wyroby, jako owiane tajemniczą symboliką i mocą artefakty wykonane z cenionego i poszukiwanego surowca, ze względu na przypisywane mu właściwości, ale również jako dowód bogactwa kraju i jego możliwości w zakresie różnorodnej, także artystycznej wytwórczości.

Wyroby gdańskie często różnią się od królewieckich typem przedmiotu, większą produkcją dewocjonaliów, konstrukcją szkatuł ze starannym doborem różnorodnych pod względem zabarwienia i przejrzystości kawałków bursztynu: nie mając dostępu do dużych brył, przerabianych Królewcu, poszukiwano w Gdańsku odmiennych efektów ${ }^{32}$. Niekiedy są to duże, okazałe obiekty o rozbudowanych programach ikonograficznych i wielości rozwiązań technicznych, zwykle oparte na drewnianym stelażu, ale przeważają małe, drobne przedmioty, należące raczej do galanterii. O ile w Królewcu wytworne naczynia powstawały w wyniku współpracy bursztynników i złotników, o tyle

30 Janusz Tondel, Biblioteka zamkowa (1529-1568) księcia Albrechta Pruskiego w Królewcu (Toruń: Wydawnictwo UMK, 1992); Janusz Tondel, Srebrna Biblioteka księcia Albrechta Pruskiego i jego żony Anny Marii (Warszawa: BN, 1994), 8-14.

31 Georg Laue, „Bernsteinarbeiten aus Königsberg für die Kunstkammern Europas: Der Meister Georg Schreiber und seine Werkstatt", w Bernstein für Thron und Altar. Das Gold des Meeres in fürstlichen Kunst- und Schatzkammern, red. Wilfried Seipel (Wien: Kunsthistorisches Museum, Alte Geistliche Schatzkammer, 2006), 23-27; Jacek Bielak, „Bursztynnictwo gdańskie od drugiej połowy XVI do początku XVIII wieku. Studium z historii nowożytnego rzemiosła artystycznego" (rozprawa doktorska, Uniwersytet Gdański, 2009).

32 Elżbieta Mierzwińska, Bursztyn w sztuce. Katalog wybranych obiektów ze zbiorów Muzeum Zamkowego w Malborku (Malbork: Muzeum Zamkowe, 1998), 29-36. 
w Gdańsku przedmioty ze „złota Bałtyku” tworzyli wyłącznie bursztynnicy, bez udziału złotników ${ }^{33}$. Trzeba też pamiętać, że liczne - zwłaszcza niezbyt wielkie - przedmioty, utensylia lub ozdoby nie dają możliwości precyzyjnego określenia miejsca wykonania; obok Królewca i Gdańska wchodzą w rachubę inne miejscowości, zwłaszcza Elbląg, a także Słupsk ${ }^{34}$, tuż za zachodnią granicą Prus Królewskich.

Szesnaste stulecie stanowi wyraźną cezurę w wytwórczości złotniczej w Prusach, z kilku powodów. Pierwszym, najbardziej oczywistym, jest zmiana języka artystycznego, rezygnacja (choć niecałkowita) z form gotyckich na rzecz późnorenesansowych i manierystycznych, a dalej, w połowie następnego wieku - barokowych. Zmiana ta ma wszakże charakter cechy ogólnej, nieograniczonej przecież do tego jednego regionu. Drugim powodem jest postępujące zróżnicowanie maniery wykonawczej - obserwowana w późnośredniowiecznych dziełach jednolitość stylu i trudność w rozróżnianiu wyrobów powstałych (wytworzonych) w różnych ośrodkach złotniczych ustępuje miejsca nasilającej się różnorodności. Trzeci wreszcie powód wynika $\mathrm{z}$ wnioskowania negatywnego i zasadza się na prawie całkowitym braku zachowanych dzieł złotniczych z tego czasu; wyjątkiem jest Królewiec. Praktycznie nieznana jest ówczesna wytwórczość w miastach Prus Królewskich; dotkliwy to brak wobec poświadczonej archiwalnie znacznej liczby czynnych warsztatów, zwłaszcza w Gdańsku.

Królewiec zasługuje na szczególniejszą uwagę. Dzięki konsekwentnie realizowanej polityce ks. Albrechta Pruskiego powstało środowisko artystyczne, złotnicze, konkurujące z Gdańskiem, w niektórych obszarach wręcz z powodzeniem. W drugiej ćwierci i w połowie XVI wieku przybyli do Królewca specjaliści wykształceni i nawet pracujący już samodzielnie w południowoniemieckich ośrodkach złotniczych (Norymberga, Ulm, Bazylea); do nich dołączyli rzemieślnicy regionalnego pochodzenia ${ }^{35}$. Dziełem tych wybitnych artystów są spektakularne insygnia (miecz ceremonialny zwany Albrechtsschwert

33 Jedynym znanym mi przedmiotem złotniczym ozdobionym kawałkami bursztynu jest nieznakowany kielich, z pewnym dość dużym prawdopodobieństwem przypisywany najważniejszemu złotnikowi 2. tercji XVIII w. - Johannowi Gottfriedowi Schlaubitzowi, Woźniak, Złotnictwo sakralne, 90, il. 589.

34 Jacek Kriegseisen, Stupskie bursztynnictwo. Wyroby słupskiego cechu bursztynniczego od XVI do początku XX wieku (Słupsk: Wydawnictwo Towarzystwa Opieki nad Zabytkami, Oddział w Słupsku, 2002).

35 Alfred Rohde i Ulla Stöver, Goldschmiedekunst in Königsberg (Bau- und Kunstdenkmäler des Deutschen Osten, Reihe B, t. 2, red. Günther Grundmann) (Stuttgart: W. Kohlhammer, 1959). 
z lat 1540-1541; para bereł uniwersyteckich z około 1544 roku $\left.^{36}\right)$, a przede wszystkim tzw. Srebrna Biblioteka - druki o treści religijnej (Biblia, kazania, komentarze, książki o treści budującej) oprawne w srebro ${ }^{37}$. Jest to największa ze znanych - zachowanych bądź szczegółowo poświadczonych - zwarta kolekcja srebrnych opraw. O ile kultura wczesnego i dojrzałego średniowiecza dostarcza wielu przykładów tak afirmatywnego i pełnego szacunku odnoszenia się do księgi, do słowa pisanego, o tyle w czasach nowożytnych ten rodzaj wywyższenia słabnie. Srebrna Biblioteka - w równej mierze rezultat dążeń, ambicji, zamiłowań artystycznych księcia i jego drugiej żony Anny Marii Brunszwickiej - jest dowodem na wyznaniowe, ewangelicko-luterańskie podłoże działań i decyzji Albrechta Pruskiego, na dążenie książęcej pary do reprezentatywności dworskiej, wreszcie na zamiłowanie do luksusu, cechujące zwłaszcza księżną ${ }^{38}$.

Spośród pierwotnie dwudziestu srebrnych opraw zachowało się do naszych czasów piętnaście, z czego dwanaście w Bibliotece Uniwersyteckiej w Toruniu, wraz z większością księgozbioru królewieckiego - połączonych bibliotek uniwersyteckiej i państwowej. Poszczególne okładziny różnią się kompozycją, ikonografią, ale też poziomem wykonawczym. Jest godne podkreślenia, że podstawowe typy kompozycyjne: centralne pola, i prostokątne szerokie bordiury, akcentowane narożniki, ornamentalne tła - należą do rozwiązań stosowanych w długiej europejskiej tradycji całościowych opraw metalowych, względnie pojedynczych okuć na powierzchni obciągniętej skórą lub aksamitem. Królewieckie woluminy pokryte są całkowicie srebrem, lecz podziały niektórych okładzin wywodzić można ze zwyczaju stosowania pojedynczych okuć. Zaobserwować też można szereg analogii pomiędzy wprowadzonymi podziałami srebrnych okładzin a schematami kompozycyjnymi dość powszechnie występującymi w oprawach introligatorskich - współczesnych, przede wszystkim jednak późniejszych, w tym także w oprawach ksiąg wchodzących w skład księgozbioru księcia Albrechta. Dekoracja reliefowa jest w mniejszości - najlepszym jej reprezentantem są repusowane partie obu okładzin, górnej i dolnej, obu niestety niezachowanych, wykonanych dla

36 Autorem tych prac jest pochodzący z Ulm Jobst Freudener, osiadły w Knipawie, zm. przed 1555 r., Rohde i Stöver, Goldschmiedekunst in Königsberg, 47, il. 3-5.

37 Tondel, Srebrna Biblioteka.

38 Michał F. Woźniak, Die Silberbibliothek aus Königsberg (1545-1562). Bestandkatalog, red. Ruth Slenczka (Potsdam: Haus der Brandenburgisch-Preußischen Geschichte; Petersberg: Michael Imhof Verlag, 2017). 
jednej z ksiąg przez przybysza z Norymbergi Corneliusa Vorwenda. W wielu innych oprawach półplastyczne są okucia naroży i klamer, a dominuje dekoracja płaszczyznowa, linearna - $\mathrm{z}$ reguły grawerowana, a sporadycznie trawiona. Przykładem jest sprowadzona z Norymbergi oprawa roboty Christopha I Rittera, po dokonanej kradzieży zachowana tylko częściowo w postaci górnej okładziny w zbiorach wawelskich. Na szczególne wyróżnienie pod względem obfitości wyobrażeń figuralnych, sposobu ich komponowania i jakości przedstawień zasługują trzy dzieła Paula Hoffmanna, przybyłego z Bazylei. (il. 7) Dwaj inni złotnicy, czynni w Królewcu od 1550 roku przynajmniej po kilkanaście lat - Gerhard Lenz, który później wyjechał do Elbląga, i Hieronymus Koesler - montowali odlewane plakiety wykonywane przez inne, wyspecjalizowane warsztaty, zarówno na miejscu, jak i w innych ośrodkach, a przede wszystkim operowali sprawnie i z dużym wyczuciem dekoracyjności ornamentem maureskowym. (il. 8, 9) Ten rodzaj ornamentu ${ }^{39}$ szczególnie nadawał się do płaskich, linearnych dekoracji, o dużych możliwościach i wariantowości wykorzystania na różnorodnego kształtu powierzchniach. Maureska popularna była zwłaszcza w drugiej i trzeciej ćwierci XVI wieku, a wzory użyte na okładzinach królewieckiego zespołu bliskie są stosowanym przez południowoniemieckich sztycharzy. Niektóre z przedstawień figuralnych oparte zostały na miedziorytach zdobiących druki pomieszczone w tychże oprawach; część z tych druków pochodziła z drukarni norymberskich, wśród innych, tłoczonych w Królewcu, czytelne są inspiracje rodem z Frankonii, choćby przez osoby typografów.

Wpływy norymberskie w innych miastach pruskich nie były już tak czytelne i tak oczywiste, choć na sformułowanie takiego osądu wpływ może mieć katastrofalny stan zachowania szesnastowiecznych sreber. Właśnie czasy późnego gotyku, renesansu i manieryzmu, czyli druga połowa XV, cały XVI i początek XVII wieku to okres największego oddziaływania Norymbergi na ziemie Europy środkowej i środkowowschodniej ${ }^{40}$. Jedynie w Gdańsku, w kilku pucharach puklowanych, powstałych już w XVII wieku, ale nawiązujących do

39 Magdalena Adamska, „Maureska - pierwszy triumf grafiki ornamentalnej”, w Ornament i dekoracja dzieła sztuki. Studia z historii sztuki, red. Joanna Daranowska-Łukaszewska, Agata Dworzak i Andrzej Betlej (Warszawa: Stowarzyszenie Historyków Sztuki, 2015), 163-174.

40 Michał [F.] Woźniak, „Zur Nürnberger Gold- und Silberschmiedekunst des 15. und 16. Jahrhunderts in Mitteleuropa“, Anzeiger des Germanischen Nationalmuseums (2002): 164-176; zmieniona wersja polska: „W kwestii złotnictwa norymberskiego w Europie środkowej w XVI wieku", Teka Komisji Historii Sztuki 9 - Towarzystwo Naukowe w Toruniu. Prace Wydziału Filologiczno-Filozoficznego 36, nr 3 (2002): 117-145. 
tradycji pucharów w kształcie orlika (Akeleypokal), które były w Norymberdze obowiązkową próbą mistrzowskąa ${ }^{41}$ można odczytać fascynację sztuką tego środowiska. Jednak te gdańskie naczynia nie operują już takimi wyraziście zakreślonymi światłami i cieniami, z ostrymi konturami i graniami pomiędzy kulistymi wypukłościami, jakie odnaleźć można w południowoniemieckich, frankońskich pierwowzorach - są raczej miękko kształtowane, z łagodniejszymi przejściami pomiędzy światłem a cieniem; złotnicy rezygnują z nacisku na wyrazistość nawet drobnoformatowego detalu na rzecz dominującej obłej, plastycznej formy. (il. 10) Uwidacznia się w tym podejściu także zmiana stylowa, zainteresowanie i preferowanie miękkiego kształtowania bryły z subtelnymi efektami światłocieniowymi ${ }^{42}$.

Miejsce Norymbergi zajmie w XVII wieku Augsburg43 oraz ośrodki północne, niderlandzkie ${ }^{44}$ i (dawne) hanzeatyckie, zwłaszcza Hamburg; wiele pokrewieństw odnaleźć można także w twórczości złotników środkowoniemieckich (Lipsk) i z Dolnej Nadrenii (Kolonia) (choć daleko im do nadreńskiego wpływu dającego się zaobserwować przy oglądzie i analizie dzieł pochodzących z XIV i XV wieku). Różnorodność tych relacji artystycznych idzie w parze z wielością dróg, którymi podążali do pruskich miast czeladnicy; wielu z nich osiadło na stałe w Gdańsku bądź w Toruniu, co wystarczająco

${ }^{41}$ Ralf Schürer, „Der Akeleypokal. Überlegungen zu einem Meisterstück“, w Wenzel Jamnitzer und die Nürnberger Goldschmiedekunst 1500-1700. Goldschmiedearbeiten - Entwürfe, Modelle, Medaillen, Ornamentstiche, Schmuck, Porträts. Eine Ausstellung im Germanischen Nationalmuseum Nürnberg (München: Klinkhardt \& Biermann, 1985), 107-122.

42 Michał [F.] Woźniak, „Prusy Królewskie a Norymberga. Garść uwag o powiązaniach w dziedzinie złotnictwa i o transferze rozwiązań w zakresie typu i formy luksusowych srebrnych przedmiotów", w Album Amicorum. Między Wilnem a Toruniem. Księga pamiątkowa dedykowana profesorowi Józefowi Poklewskiemu (Toruń: Wydawnictwo Naukowe UMK, 2008), 384-391.

43 Na znaczenie Augsburga wskazałem w jednej z moich wczesnych prac, zob. Michał [F.] Woźniak, „Wpływy augsburskie w złotnictwie gdańskim XVII-XVIII stulecia”, Biuletyn Historii Sztuki 47 (1985): 95-126; zagadnienie to podjął także Jacek Kriegseisen, „Związki złotników Prus Królewskich z Augsburgiem w XVII i pierwszej połowie XVIII wieku na przykładzie Gdańska, Elbląga i Torunia”, w Ex voto. Studia dedykowane Ojcu Janowi Golonce OSPPE, red. Przemysław Mrozowski i Jerzy Żmudziński (Częstochowa: Jasnogórska Fundacja Pro Patria i Wydawnictwo Czuwajmy, 2012), 627-636.

44 Znaczenie Niderlandów sygnalizowało, najczęściej nadzwyczaj lakonicznie i w odniesieniu do północnych prowincji, wielu badaczy; z ważniejszych opracowań zob. np. Andrzej Fischinger, „Uwagi nad twórczością Andrzeja Mackensena I złotnika krakowskiego i gdańskiego", Sprawozdania z Posiedzeń Komisji Naukowych PAN, Oddział w Krakowie 13 (1969): 173-175; zob. też Michał [F.] Woźniak, „Elementy niderlandzkie w złotnictwie gdańskim XVII wieku”, w Studia z historii sztuki i kultury Gdańska i Europy Pótnocnej. Prace poświęcone Doktor Katarzynie Cieślak, red. Jacek Friedrich i Edmund Kizik (Gdańsk: Stowarzyszenie Historyków Sztuki, Oddział Gdański, 2003), 239-255. 
dobrze jest czytelne w cechowych źródłach pisanych. Do tego należy odnotować aktywność złotników w wielu średnich miastach, takich jak Malbork, Chojnice, Brodnica, a nawet małych, takich jak ośrodki warmińskie: Orneta, Dobre Miasto, Lidzbark, Olsztyn - by poprzestać na tych kilku przykładach. Do rangi średnich miast spadło też Braniewo, natomiast Elbląg starał się zachować swe wcześniejsze znaczenie ${ }^{45}$, choć z trudem radził sobie z konkurencją Gdańska i Królewca.

Niewątpliwie najważniejszym pruskim ośrodkiem złotniczym pozostawał Gdańsk, przynajmniej pod względem różnorodności produkcji wyprzedzając Królewiec. W Prusach Królewskich zaś drugie miejsce po Gdańsku zajmował Torun - wprawdzie jeśli chodzi o liczbę czynnych warsztatów trzykrotnie mniejszy, lecz w zakresie wytwórczości sreber kościelnych równowartościowy partner Gdańska. Toruń wykorzystywał swe dogodne położenie na styku Prus i ziem koronnych, dostarczając liczne aparaty liturgiczne do katolickich kościołów nie tylko ziemi chełmińskiej, ale także Kujaw i Mazowsza. Srebra kościelne gdańskiej roboty, obecne oczywiście w najbliższym sąsiedztwie miasta, występują też na dużym obszarze Rzeczypospolitej. Spław zboża, drewna i potażu - ważnych surowców i produktów eksportowych ziem polskich - do Gdańska odbywał się Wisłą i jej dopływami; podobnie, niejako powrotną drogą, korzystając z tych samych wodnych szlaków i kierunków komunikacyjnych, rozprowadzano srebrne wyroby. Właściciele lub ich pełnomocnicy po sprzedaży spławianego towaru zaopatrywali się bezpośrednio w Gdańsku w potrzebne i pożądane artykuły: niedostępne na lokalnym rynku w głębi kraju, a przynajmniej nie takiej jakości, nie w tak konkurencyjnych cenach. Dzięki dalekosiężnym kontaktom handlowym Gdańsk był znaczącym centrum nie tylko produkcji, ale także importu i zbytu luksusowych towarów sprowadzanych z zagranicy. Oprócz aparatów kościelnych w równym lub większym nawet zakresie były w Gdańsku dostępne takie sprzęty, jak karoce, zegary, klejnoty, srebra stołowe ${ }^{46}$. Te zbytkowne przedmioty przetrwały

45 Jacek Kriegseisen, „Złotnictwo elbląskie od XIV do początku XIX wieku (do 1827 r.)” (rozprawa doktorska, Uniwersytet Gdański, 2005); Jacek Kriegseisen, „Złotnictwo elbląskie od XVI do końca XVIII wieku”, w Klejnot w koronie Rzeczypospolitej. Sztuka zdobnicza Prus Królewskich. Eseje, red. Czesława Betlejewska (Gdańsk: Muzeum Narodowe, 2006), 72-79. Kriegseisen zdaje się z nadmierną przesadą oceniać wielkość i znaczenie elbląskiego ośrodka złotniczego w czasach nowożytnych.

46 Adam Grabowski, przedstawiciel średniozamożnej szlachty pomorskiej, po uzyskaniu nominacji królewskiej na biskupstwo chełmińskie, niezbyt bogato uposażone, a następnie prekonizacji papieskiej 26 IX 1736 r., jeszcze przed objęciem diecezji zaopatrzył się w Gdańsku 
w znikomym stopniu; o wiele lepszy, zdecydowanie najlepszy jest stan zachowania sprzętów liturgicznych. (il. 11)

Dla oblicza Torunia jako ośrodka złotniczego we wczesnej nowożytności szczególną rolę odgrywają srebra kościelne - co oczywiście nie znaczy, że w tym mieście (i podobnie w Elblągu) nie wykonywano okazałych, dobrej jakości sreber świeckich. Najstarsze toruńskie przedmioty liturgiczne, poświadczone znakami złotniczymi: miejskim i warsztatowym, pochodzą już z przełomu XVI i XVII wieku; wraz z upływem czasu liczba ich wzrasta. Podobne gdańskie naczynia datowane są dopiero od drugiej ćwierci, a nawet połowy XVII stulecia. Ponadto w Toruniu w tym wcześniejszym okresie zaznaczyło się wyraźnie ciekawe zjawisko dwoistości stylowej. Monstrancje eucharystyczne i relikwiarze wykonywane były w formach późnogotyckich i postgotyckich, natomiast kielichy mszalne i lichtarze ołtarzowe w formach renesansowo-manierystycznych, przy stopniowym - wraz z upływem czasu - wzroście cech barokowych ${ }^{47}$. (il. 12, 13)

Wytwórczość ta - po całkowitym załamaniu fundacji kościelnych w drugiej ćwierci XVI wieku - zbiegła się w czasie z ich ponownym znaczącym wzrostem po około 1590/1600 roku. Uwidoczniła się wtedy, wsparta konsekwentną polityką królewską, zdecydowane dążenie Kościoła katolickiego na rzecz odnowy katolicyzmu w duchu soboru trydenckiego i w kontraście z konfesjami ewangelickimi. Miasta w Prusach Królewskich trwały stanowczo przy wyznaniu luterańskim, przy stopniowym marginalizowaniu kalwinizmu ${ }^{48}$, natomiast region - małe miasta i wsie oraz szlachta - pozostali

(podczas pobytu trwającego od jesieni 1737 aż do połowy roku następnego) w niezbędne utensylia - karety, wóz, konie, skompletował liczne meble, sprzęty kuchenne, naczynia cynowe i ceramiczne, ponadto ks. Loka zamówił dla niego u złotnika Michaela Dietricha srebrną zastawę stołową za blisko 26 tys. złp,, a u innych złotników dodatkowo półmiski oraz kielich mszalny i „puszkę na sakramenty” - zob. Jerzy Dygdała, Adam Stanisław Grabowski (1698-1766). Biskup, polityk, mecenas (Olsztyn: Ośrodek Badań Naukowych im. Wojciecha Kętrzyńskiego, 1994), 43-44.

47 Woźniak, Złotnictwo sakralne, 293-296, 315-319. Na zjawisko to po raz pierwszy zwróciłem uwagę we wcześniejszym artykule - zob. Michał [F.] Woźniak, „Tradycjonalizm i modernizacja sprzętów liturgicznych w Prusach Królewskich w okresie nowożytnym”, w Rozważania o smaku artystycznym, red. Józef Poklewski i Tomasz F. de Rosset (Toruń: Wydawnictwo UMK, 2002), 55-77.

48 O relacjach w Gdańsku między luteranizmem a kalwinizmem w dążeniu do ponownej reformacji w duchu tego drugiego wyznania, zwłaszcza w kręgach patrycjatu, o reakcji pospólstwa przychylnego tej pierwszej konfesji i o zwycięstwie ortodoksji ewangelicko-augsburskiej pisze wyczerpująco Katarzyna Cieślak, Między Rzymem, Wittenbergą a Genewą. Sztuka Gdańska jako miasta podzielonego wyznaniowo (Wrocław: Wydawnictwo Leopoldinum Fundacji dla Uniwersytetu Wrocławskiego, 2000). 
w większości przy katolicyzmie albo doń wracali. W opozycji do protestantyzmu, odrzucającego kult eucharystii (konsekrowanych postaci, wraz z przechowywaniem i adoracją hostii) i nieakceptującego czci oddawanej świętym (zatem także ich relikwiom), Kościół katolicki - kler i wierni, fundatorzy i odbiorcy - starali się podkreślać „odwieczność”, długotrwałość tych praktyk pobożnościowych (choć kult eucharystyczny narastał dopiero od początków XIV wieku). W tym celu m.in. dla zamawianych monstrancji i relikwiarzy wybierali formy i typy gotyckie, nieznacznie modernizowane; szczególnie charakterystyczne były pod tym względem monstrancje retabulowe. Natomiast kielichy - czyli naczynia niekwestionowane w trakcie polemik wyznaniowych, niezbędne podczas liturgii niezależnie od konfesji - sporządzano w nowym kształcie i nowych formach stylowych ${ }^{49}$. Kielichy takie, jak również garnitury ołtarzowe, składające się z krucyfiksu wraz z lichtarzami, były widomym znakiem przyjęcia reform soborowych, aktywnej katolickiej postawy. Wiele tych najstarszych sprzętów ufundowali przedstawiciele wyższego duchowieństwa - biskupi i prałaci. Wszystkie one wzorowane są na kielichach i lichtarzach włoskich, wykonywane były zatem more italico, more romano. W całej Rzeczypospolitej liczba tego typu kielichów powstałych w pierwszej tercji XVII wieku jest imponująca, idzie w setki zachowanych sztuk; świadczy to o masowości produkcji i szerokim przyjęciu modelu włoskiego, jak w żadnym innym kraju europejskim ${ }^{50}$.

Odrębności kompozycyjne zachodzące między poszczególnymi egzemplarzami są niewielkie: w ciągu pierwszej tercji XVII wieku zauważalna jest powolna, stopniowa zmiana proporcji oraz stosowanej ornamentyki; z powodów oczywistych widoczne są różnice w jakości wykonania. Niemożliwe jest jednak dla zdecydowanej większości zabytków jednoznaczne określenie miejsca wykonania - pewnymi wskazówkami mogą być (bardzo rzadkie) dane pochodzące ze źródeł pisanych lub znaki własnościowe bądź wykonawcze na kielichach. Pośród znakowanych - wcale nie tak licznych - najbardziej znaczącą i największą grupę stanowią dzieła pochodzące z ośrodków pruskich, przede wszystkim z Torunia. Najstarszy zidentyfikowany kielich o cechach

49 Na ziemiach polskich nie zaznaczyła się tendencja - znana z bardziej rygorystycznych gmin reformowanych w Szwajcarii i Niderlandach - używania w liturgii podczas komunii (Wieczerzy Pańskiej) zamiast kielichów prostych kubków, srebrnych lub cynowych, takich jak w użyciu domowym, świeckim, zob. Johann Michael Fritz, Das evangelische Abendmahlsgerät in Deutschland. Vom Mittelalter bis zum Ende des Alten Reiches (Leipzig: Evangelische Verlagsanstalt, 2004), 27, 108-109, 208-209, 212-220, 226-227, 237-238.

50 Woźniak, Złotnictwo sakralne, 54-61. 
nowożytnych, powstały około 1600 roku, jest dziełem toruńskiego złotnika Albrechta I Weimmera ${ }^{51}$; kolejny, może kilka lat późniejszy - Jana Lettaua, czynnego w warmińskim Braniewie ${ }^{52}$.

Jedne i drugie sprzęty - zarówno postgotyckie, jak i nowoczesne, monstrancje i relikwiarze oraz kielichy i garnitury ołtarzowe - fundowane były z myślą o manifestacji postawy katolickiej, polemicznej wobec wyznania ewangelickiego. Sytuacja uległa zmianie w połowie stulecia: we wszystkich rodzajach naczyń dochodziły do głosu formy barokowe, zanikała tendencja postgotycka, rozpowszechniały się monstrancje promieniste, słoneczne, widomy znak tryumfującego Kościoła katolickiego. Pierwsze takie ostensoria powstały - i w Toruniu, i w Gdańsku - około 1650 roku. Natomiast tylko w Toruniu jako jedynym ośrodku na obszarze Rzeczypospolitej w drugiej i trzeciej ćwierci XVII wieku wytwarzano osobliwe monstrancje „mieszane”, łączące cechy ostensoriów postgotyckich i słonecznych. W obiektach tych niewielki okrąg promieni był otoczony konstrukcją detali architektonicznych i ornamentalnych pochodzących z zasobu dekoracyjnego dawnych monstrancji wieżowych i retabulowych. Osobliwość polega nie tylko na hybrydycznym niejako charakterze tych naczyń, ale też na niepokojącym zestawieniu elementów radialnych i wertykalnych. Owe toruńskie monstrancje swoje odpowiedniki mają jedynie w wytwórczości (również dość marginalnej przy tym) złotników południowoniemieckich z lat trzydziestych i czterdziestych XVII wieku (augsburskich, monachijskich) ${ }^{53}$.

Reminiscencje i pozostałości budowy monstrancji postgotyckich długo przetrwały w tradycji warsztatowej toruńskich mistrzów i są czytelne przynajmniej do schyłku XVII wieku, choć na pozór mamy do czynienia z wykształconymi rozwiązaniami promienistymi. Najdłużej, bo do końca cechowej wytwórczości, czyli do przełomu XVIII i XIX stulecia pozostały ramiona, wolutowe twory odchodzące od trzonu, zapełniające przestrzeń pomiędzy stopą a glorią, zaopatrzone na końcach w figurki przedstawiające świętych lub aniołów. Anioły ujęte są zwykle w pozie adorującej, czasem ustawione fron-

51 Po raz pierwszy opublikowany w Michał [F.] Woźniak, „Sprzęty liturgiczne w kościele SS. Miłosierdzia (d. Benedyktynek) w Chełmnie. Z badań nad złotnictwem na ziemi chełmińskiej XVII-XVIII w.", Acta Universitatis Nicolai Copernici. Zabytkoznawstwo i Konserwatorstwo 10 (1982): 158, il. 25, 27, 29; Woźniak, Złotnictwo sakralne, 54-55, il. 21, 578.

52 Okulicz, Złotnictwo sakralne, s. 114-115, nr 28; Woźniak, Złotnictwo sakralne, s. 54-55, il. 22.

53 Michał [F.] Woźniak, „Rozwój formy monstrancji promienistych z warsztatów złotniczych Torunia”, Acta Universitatis Nicolai Copernici. Zabytkoznawstwo i Konserwatorstwo 13 (1989): 127-131; Woźniak, Złotnictwo sakralne, 124-126. 
talnie, statuarycznie. Z kolei wyobrażenia świętych są najczęściej upozowane frontalnie, co nieodparcie przywołuje wspomnienie figurek umieszczanych w prześwitach bocznych monstrancji retabulowych, postgotyckich. Ramiona natomiast wywodzą się w prostej linii z wolutowych podpór poziomej belki cokołowej tego retabulum. Złotnicy toruńscy wprawdzie konsekwentnie czego nie sposób im odmówić, lecz niezwykle powoli i mozolnie kształtowali, konstruowali monstrancję promienistą, wychodząc od owych form mieszanych, aż po kompozycyjnie zrównoważoną bryłę. Składa się ona z budowanej na owalu stopy, tralkowego trzonu, wolutowych ramion bocznych, niezbyt rozbudowanego słońca z ograniczoną liczbą figuralnych wyobrażeń. Etapem końcowym tego rozwoju, w sensie zarówno logiki zmian, jak i jakości artystycznej rozwiązań, są monstrancje Jakuba Weintrauba (czynnego w latach 1692-1728), niewątpliwie najważniejszego toruńskiego złotnika doby baroku. (il. 14) Niebywałe - proces ten trwał kilkadziesiąt lat, obejmując trzy generacje złotników o różnym pochodzeniu, w tym także przybyszów z odległych stron, którzy wtopili się w miejscową tradycję. Końcowy efekt jest całkowicie odmienny od modelu przeważającego w Niemczech południowych i w monarchii habsburskiej, czyli w katolickich krajach Europy środkowej. Tam z upodobaniem stosowana była wielka, mandorlowa gloria osadzona na krótkim trzonie, z rozmieszczoną na tle promieni, w kilku planach warstwą dekoracyjną złożoną z rozbudowanych przedstawień figuralnych, czasem scen wielofiguralnych oraz obfitego ornamentu. W rezultacie dominowała plastyczna, dwu- lub trzywarstwowa gloriola, z widocznymi jedynie zakończeniami promieni.

Gdańscy złotnicy postępowali odmiennie niż ich toruńscy koledzy i konkurenci. W miejsce znacznego ujednolicenia wprowadzili duże zróżnicowanie typów i form. O ile stosunkowo łatwo można odróżnić i rozpoznać toruńską monstrancję wśród wytworów złotników z innych ośrodków, znacznie zaś trudniej, wobec tej jednolitości stylowej, określić jej autora (oczywiście jeśli nie zostały wybite lub też rozpoznane znaki warsztatowe, znakomicie ułatwiające atrybucję), o tyle w przypadku gdańskiej odwrotnie - czasem ta rozmaitość wprawia wręcz w osłupienie, tak jest różnorodna, bogata i kosmopolityczna. Poszczególni gdańscy złotnicy z reguły trzymali się własnych wypracowanych lub zapożyczonych z zewnątrz rozwiązań. Różnice pomiędzy nimi są łatwo dostrzegalne, a ich wyroby są względnie łatwo rozróżnialne; przy czym tylko sporadycznie realizowali swe ostensoria w dwóch różnych wariantach typologicznych. Dopiero stosunkowo późno Johann Gottfried 
Schlaubitz, bezsprzecznie najwybitniejszy złotnik czynny w Prusach Królewskich, prowadzący swój warsztat w drugiej tercji XVIII wieku, jako jedyny stosował kilka różnorodnych rozwiązań, każde w kilku egzemplarzach. Zarazem Schlaubitz, syn także gdańskiego złotnika Nathanaela, dominującego na lokalnym rynku w pierwszej ćwierci XVIII wieku, potrafił dokonywać syntezy formy plastycznej, zmonumentalizowanej i skoncentrowanej na dekoracyjnym, drobnym szczególe, tektonicznie zwartej, konsekwentnie budowanej, a zarazem przetworzonej w ornament, dostrajającej się do jego morfologii oraz do nadrzędności ornamentalnego języka. (il. 15) Korzystając z różnych zewnętrznych doświadczeń, inspiracji i wpływów, doszedł do własnego stylu, własnego idiomu, własnego języka artystycznego. Swoim dziełom nadawał wyrazistą, czasem nawet twardo opracowaną formę, która wcale nie pozostaje w sprzeczności z ornamentem rocaille’owym; jego kapryśne, muszlowego kształtu elementy stosował z umiarem, wprowadzając także charakterystyczne pasowe, plastyczne motywy. Twórca ten zaczął używać rocaille’u stosunkowo wcześnie, spośród polskich złotników bodaj najwcześniej (uwzględniając nie tylko Gdańsk i Prusy Królewskie, ale także inne ośrodki Rzeczypospolitej). Zarazem w kilku dziełach powstałych około 1750 roku zdradził znajomość nowatorskich rozwiązań francuskich, przesuwając obszar, z którego czerpano w Prusach inspiracje, na zachód, poza obszar Świętego Cesarstwa i regiony ściśle z nim związane. Za przykład może służyć monstrancja z katedry we Fromborku, oparta na projekcie Juste-Aurèle Meissonniera przeznaczonym dla kościoła Karmelitów w Poitiers ${ }^{54}$ (echa inspiracji projektami sprzętów kościelnych tego złotnika i projektanta królewskiego dostrzec można także w innych dziełach Schlaubitza). Zależność jest znacznie głębsza i bardziej istotna, dotyka istoty kształtowania formy przedmiotu, tożsamej ze strukturą tego ornamentu (tj. rocaille’u), z jego plastycznymi taśmami prowadzonymi giętką linią, eksponującymi zarazem plastyczność i twardość. Zgodnie z koncepcją forme rocaille te plastyczne taśmy nie rozwijają się na płaszczyźnie, lecz ogarniają cały trójwymiarowy przedmiot; logikę ich przebiegu rozpoznać można oglądając przedmiot ze wszystkich

54 Po raz pierwszy o tej inspiracji wspomina, niezbyt precyzyjnie, Bogusław Kopydłowski, „Monstrancja rokokowa”, w Sztuka zdobnicza. Dary i nabytki 1945-1964, red. Stanisław Gebethner (Warszawa: Muzeum Narodowe, 1964), 63; wskazówkę tę wykorzystał i zagadnienie rozwinął Roman Nielubszyc, „Jan Gotfryd Schlaubitz - gdański złotnik XVIII wieku”, Biuletyn Historii Sztuki 38 (1976): 239-254; zob. także Woźniak, Złotnictwo sakralne, 152; Okulicz, Złotnictwo sakralne, 410, 412; Michał F. Woźniak, „Złotnicy i ich ornament”, w Ornament, 62-65. 
stron. (il. 16) Poznanie i przyswojenie takiego sposobu zarazem opracowania przedmiotu i jego dekorowania jest raczej mało prawdopodobne wyłącznie za pomocą różnych wzorników, projektów graficznych. Twórca tych dzieł musiał mieć bezpośredni kontakt $\mathrm{z}$ francuskimi wzorami na etapie produkcyjnym, nie wystarczył ogląd gotowego dzieła lub samego tylko wzoru graficznego ${ }^{55}$.

Siegfried Oernster, Nathanael i Johann Gottfried Schlaubitzowie, Johann Joede, członkowie rodziny Rhode (Rohde, Rode) oraz rodziny Haase i wielu innych w Gdańsku, Johann I i Johann II von Hausenowie, Nicklaes i Johann Christian Broellmannowie, Jakob Weintraub w Toruniu - artyści ci, będąc ewangelikami, wykonywali liczne aparaty dla katolickich fundatorów, przeznaczone do katolickich kościołów w Prusach Królewskich i na innych ziemiach Korony. Zamówienia na sprzęty liturgiczne protestanckie: do świątyń luterańskich i (rzadziej) kalwinistycznych napływały już nie tak często. Kościół katolicki - duchowni i wierni - był dla tych protestanckich złotników bardzo ważnym i cennym zleceniodawcą. Wbrew rozpowszechnionej opinii kielichy kościołów ewangelicko-augsburskich, zarówno w Gdańsku, jak i w Toruniu, były bardzo często bogato zdobione, także przedstawieniami figuralnymi ${ }^{56}$, i prawie niczym się nie różniły się od katolickich; może preferowaniem tematyki pasyjnej, a unikaniem scen z Dzieciństwa Jezusa (właściwie: Inkarnacji). Wykonywano oczywiście także kielichy gładkie, ale podobne sprawiano również i do kościołów katolickich. Różnicę w wyposażeniu kościołów ewangelickich stanowił brak wielu sprzętów kultowych typowych dla liturgii katolickiej; w zamian były w nich hostierki (o których niewiele wiadomo) oraz dzbany komunijne (inaczej dzbany do Wieczerzy Pańskiej, Abendmahlskannen). (il. 17, 18) Te drugie bywały całkowicie gładkie, czasem z delikatnie wprowadzonymi elementami dekoracji techniką grawerowania, nieingerującą w zwartą, kubiczną formę cylindrycznego naczynia. Owe gładkie dzbany mają wiele odpowiedników w innych regionach środkowej Europy. W Gdańsku dość często na korpusy dzbanów wprowadzona została dekora-

55 Na marginesie tylko dodam, że Meissonnier na zlecenie oraz marszałka wielkiego koronnego Franciszka Bielińskiego oraz księcia Augusta Aleksandra Czartoryskiego (z przeznaczeniem dla jego żony Marii Zofii Sieniawskiej, $1^{\circ}$ voto Denhoffowej) wykonał projekty dekoracji do ich pałaców - odpowiednio gabinetu w Warszawie i salonu w Puławach, zob. Stanisław Lorentz, „Projets pour la Pologne de Juste-Aurel Meissonier”, Biuletyn Historii Sztuki 20 (1958): 186-198; Peter Fuhring, Juste-Aurèle Meissonnier: un génie du rococo 1695-1750 (Turin-London: Umberto Allemandi, 1999), 16, 41-42, 118-126, 213-214, 240, 245-248, 288-290, 296-297, 356-359, 362, 391, 402, 404-405, 453, 459-460.

56 Zwraca na to uwagę Fritz, Das evangelische Abendmahlsgerät, passim. 
cja repusowana, reliefowa, wzbogacając wygląd naczynia. W kościołach tego miasta można też obserwować zwyczaj fundowania kolejnych dzbanów do danego kościoła, wykonywanych na wzór najstarszego sprawionego doń naczynia, będących bardziej lub mniej wiernymi kopiami lub replikami egzemplarza wyjściowego, modelowego. Ponieważ dekoracja jest dość oszczędna, różnice w ornamentyce - doborze, ukształtowaniu i zestawieniu motywów - nie są wcale tak widoczne i oczywiste ${ }^{57}$. Wyroby elbląskie i toruńskie tego rodzaju są pojedynczo zachowane, zbyt jednostkowe, wręcz unikatowe, by mogły stanowić podstawę dla ogólniejszych sądów. Sporadycznie w Gdańsku, a znacznie częściej w Królewcu pojawiły się w XVII wieku tzw. dzbany hanzeatyckie (Hansekannen), wzorowane na lubeckich, które swoje odpowiedniki mają także w wyrobach złotników inflanckich - w Rydze i Tallinie (Revalu) ${ }^{58}$. Również w Królewcu złotnicy ewangelickiego wyznania realizowali zamówienia katolickie, przede wszystkim dla kościołów na Warmii, skutecznie konkurując na tym obszarze ze złotnikami lokalnymi i elbląskimi ${ }^{59}$.

W zakresie sreber świeckich szczególną rolę odgrywały kufle. Wytwarzane były masowo różne naczynia przeznaczone do konsumpcji alkoholu, zwłaszcza kubki: (il. 19) wsparte na nóżkach i zaopatrzone w pokrywy lub ich pozbawione, zróżnicowane wielkością, bardziej lub mniej okazałe i dekorowane, przeznaczone do użytku domowego, świątecznego, podawane podczas ceremonii cechowych, upamiętniające osoby lub wydarzenia (uwieczniany na nich był np. król Jan III Sobieski jako zwycięzca spod Wiednia i bohater wojen Rzeczypospolitej z Turkami) ${ }^{60}$. Powstawały w dużym asortymencie srebra stołowe, w ciągu XVIII wieku coraz liczniejsze serwisy, co było typowe dla tego czasu - od normy odbiegałby dopiero brak takich wyrobów; ta wytwórczość

57 Michał [F.] Woźniak, „Liturgische Gefäße der protestantischen Kirchen in Königlich Preußen“, w Kościół i sztuka pobrzeża Bałtyku. Kirche und Kunst im Ostseeraum (Studia Borussico-Baltica Toruniensia Historiae Artium, t. 3, red. Michał [F.] Woźniak) (Toruń: Wydawnictwo UMK, 1998), 210-254; Woźniak, Złotnictwo sakralne, 254-280.

58 Michał [F.] Woźniak, „Die Goldschmiedekunst in Norddeutschland, im ehemaligen Ordensland und in Livland. Überlegungen zur Frage: Gibt es einen `hanseatischen Stil’?", w Hansestadt - Residenz - Industriestandort, red. Beate Störtkuhl (Schriften des Bundesinstituts für Kultur und Geschichte der Deutschen im östlichen Europa, t. 19) (München: R. Oldenbourg Verlag, 2002), 47-65.

59 Woźniak, Złotnictwo sakralne, 287-289.

60 Andrzej Fischinger i Dariusz Nowacki, Złotnictwo dawnych Prus Królewskich i Książęcych w zbiorach Zamku Królewskiego na Wawelu. Goldsmith's Work from the Former Royal and Ducal Prussias in the Collections of the Wawel Royal Castle (Kraków: Zamek Królewski na Wawelu, 2000), 70-76; Anna Frąckowska, „Wizerunki Jana III na srebrach gdańskich”, Studia Wilanowskie 25 (2018): 123-151. 
skoncentrowana była w Gdańsku. Srebra kredensowe: puchary, dzbany, misy były stale produkowane w Gdańsku i w Królewcu, w Elblągu zaś i w Toruniu raczej sporadycznie.

Kufle stanowią podstawowy typ świeckiego reprezentacyjnego naczynia w miastach pruskich ${ }^{61}$ (a także na rozległych obszarach Europy środkowej i północnej). (il. 20, 21) Ponownie najwięcej zachowanych egzemplarzy pochodzi z dwóch ośrodków - Gdańska i Królewca; kufle elbląskie i toruńskie, niektóre wybitnej jakości, dotrwały sporadycznie. Naczynia te bywały różnej pojemności i spełniały obok reprezentacyjnej także funkcję przedmiotów pamiątkowych - np. jako składnik darów zaręczynowych, ślubnych, nawet chrzcielnych. Małemu dziecku lub nowożeńcom dawano często w prezencie, jako symboliczny zadatek przyszłej pomyślności, okazałe srebrne monety talarowe; te umieszczano następnie (by nie uległy rozproszeniu) w naczyniu - mógł to być kubek albo misa, zwykle jednak wybierano kufel, inkrustując numizmatami korpus, dno i pokrywę. Takie monetowe kufle szczególnie preferowano w Królewcu. (il. 22) Obok wprawiania monet i medali drugim rodzajem dekoracji były grawerowane bądź - nierównie częściej - reliefowe wyobrażenia i przedstawienia, zwłaszcza w Gdańsku. Ich tematyka, nawet starotestamentowa, niejednokrotnie odnosiła się do sakramentu chrztu lub obrzędu ślubu. Tematyka biblijna nie może dziwić w obyczajowości luterańskich rodzin - kufle te bowiem przede wszystkim adresowane były do warstw zamożnego mieszczaństwa. Korpus kufla zazwyczaj opasywała jedna scena, niczym fryz figuralny, lub dwie, rozdzielone na osi, w której umieszczony jest uchwyt. W Gdańsku stosowano też inny schemat: w wydzielonych polach, kartuszach prezentowano różne wyobrażenia, a pozostałą powierzchnię korpusu ozdabiano ornamentem. Pierwszy sposób zapewniał ciągłość oglądu fryzowo rozegranej sceny; drugi umożliwiał umieszczenie autonomicznych przedstawień i zapewniał rytmiczność kompozycji (np. personifikacje cnót albo pór roku i miesięcy).

Kufle konstruowano dwojako - z płaszczem pojedynczym lub podwójnym. W tym drugim wypadu dekoracja plastyczna zrealizowana była w warstwie zewnętrznej, wewnętrzna zaś była całkowicie gładka. Większość naczyń była „jednowarstwowa”: w cylindrycznym zazwyczaj korpusie wykonywana była dekoracja; jest to oczywiste, jeśli ornament został grawerowany; jeśli repuso-

${ }^{61}$ Fischinger i Nowacki, Złotnictwo dawnych Prus, passim; Anna Frąckowska, Srebrne kufle gdańskie XVII i XVIII wieku. Typologia, stylistyka, ikonografia (Warszawa: Arx Regia, 2013). 
wany - wówczas w niezbyt wysokim i niezbyt szczegółowym reliefie, z powodu sporej niekiedy grubości blachy, koniecznej dla zapewnienia funkcjonalności naczynia. Naturalnie złotnik mógł, po ogólnikowym opracowaniu reliefu techniką repusowania, zawsze od lewej strony, od odwrocia, przystąpić do kształtowania dekoracji po stronie licowej, prawej, w procesie stosunkowo głębokiego i precyzyjnego cyzelowania. Technika wykonania plastycznego reliefu: dość wysokiego, a przy tym niezwykle precyzyjnego, rozwijała się od schyłku XVII wieku, szczególną popularność osiągając w następnym stuleciu. Bardziej rozbudowane reliefy zwykle realizowano zatem w oddzielnym arkuszu blachy, nakładanym jako zewnętrzna warstwa kufla czy dzbana, opasująca tę wewnętrzną, „użytkową”. W zależności od budowy naczynia (jedno- lub dwuwarstwowej) inaczej konstruowano podstawę, odmienny był też sposób jej montażu z korpusem. Wrażenie większej masywności kufli królewieckich spotęgowane jest jeszcze formą uchwytu, sporządzanego z ornamentalnej, plastycznej woluty lub - podobnie jak u większości kufli z regionów północnych - w kształcie wydatnej, gładkiej woluty o graniastym przekroju. Kufle gdańskie są wyposażone w bardziej rozczłonkowane i elegancko uformowane uchwyty w kształcie podwójnej esownicy, o przeciwległym przebiegu części wklęsłej i wypukłej; podobne wykonywali złotnicy augsburscy, jednak ze znacznie bardziej delikatnego, wiotkiego elementu. Można to, ten element naczynia - w pewnym uproszczeniu - scharakteryzować następująco: złotnicy gdańscy sięgnęli po formę zrównoważoną, zdecydowanie członowaną i plastyczną zarazem, stojącą niejako pomiędzy delikatnością augsburską a masywnością północną. Wyraz plastyczny kufli zarówno gdańskich, jak i królewieckich zbliżony jest natomiast do znanego z innych ośrodków północnych, zwłaszcza z Hamburga, ale też Lipska. Naczynia te stanowią one zatem typowy wyrób kultury Europy północnej; złotnicy pruscy, zwłaszcza gdańscy, wypracowali w tych szerszych ramach własne warianty wyróżniające się indywidualnymi cechami.

W ciągu XVIII wieku, zwłaszcza jego drugiej połowy, stopniowo pogarszała się jakość wyrobów złotniczych w Prusach, zmniejszała się też produkcja pod względem ilościowym. Najwcześniej nastąpiło to w małych ośrodkach; jeden z nich - w Brodnicy przestał funkcjonować jako (lokalny wprawdzie) ośrodek złotniczy praktycznie już w końcu XVII względnie na początku XVIII wieku ${ }^{62}$. Liczba wyrobów wychodzących $\mathrm{z}$ warsztatów mistrzów osiadłych

62 Tadeusz Chrzanowski i Marian Kornecki, „Brodnica - nieznany ośrodek złotniczy”, Folia Historiae Artium 17 (1981): 133-145; Jacek Tylicki, Materiały archiwalne do biografii artystów w nowożytnej Brodnicy (Brodnica: Muzeum, 2014). 
w miastach warmińskich wprawdzie była dość spora ${ }^{63}$, ale osiągały one z reguły poziom ledwie zadowalający, a tylko nieliczne dobrą jakość. Malbork także nie wybijał się ponad przeciętność. Katastrofalnie doświadczony wypadkami wojennymi Elbląg podupadał, co jest widoczne także w jego pozycji ekonomicznej jako centrum handlowo-produkcyjnego, choć niektóre dzieła - niestety odosobnione i pochodzące jeszcze z XVII stulecia - zachwycają formą i techniką wykonania. Toruń po zamieszkach wyznaniowych w 1724 roku (tzw. tumult toruński, Thorner Blutbad - określenia powstałe na użytek propagandy nieprzyjaznej Polsce oraz Kościołowi katolickiemu i szerzej katolicyzmowi) i ostrej na nie reakcji królewskiej popadł w długotrwały kryzys skutkujący drastycznym ograniczeniem produkcji, zmniejszeniem liczby czynnych warsztatów; podupadł także pod względem jakości wykonawczej, co uwidoczniło się z całą mocą po połowie stulecia ${ }^{64}$. Dłużej dotychczasowy zakres produkcji starał się utrzymywać Królewiec, ale i tam w drugiej, a zwłaszcza trzeciej ćwierci XVIII wieku nastąpiła znacząca stagnacja. Jedynie Gdańsk aż po ostatnią ćwierć stulecia utrzymywał wysoki poziom, sukcesywnie jednak - na polskim rynku zbytu wystawiony na konkurencję Warszawy, po pierwszym rozbiorze Polski w 1772 roku odcięty od polskiego zaplecza wysokimi cłami pruskimi - „zwijał” działalność wytwórczą, tracąc definitywnie znaczenie. Dawnej roli, pomimo wysiłków podejmowanych w XVIII i na początku XIX wieku, nie odzyskało ani miasto nad Motławą, ani też Królewiec. Potencjał wykonawczy przesunął się do innych ośrodków, rękodzieło coraz silniej wypierane było przez duże zakłady, wykorzystujące zmechanizowane sposoby produkcji, wiodące do powtarzalności form i seryjności. Indywidualnie zaprojektowane i wykonane dzieła należały do zdecydowanych wyjątków.

Względna otwartość regionu na oddziaływania zewnętrzne przejawiała się w przejmowaniu inspiracji artystycznych, także w wyniku wędrówek czeladniczych i wymiany fachowych kadr. Stopniowo dało się jednak zauważyć zamykanie się poszczególnych ośrodków na wpływy zewnętrzne - jeszcze w późnym średniowieczu przybysze stanowili nawet około dwóch trzecich liczby nowych mistrzów cechowych, u progu nowożytności proporcje na-

63 Joseph Kolberg, „Ermländische Goldschmiede“, Zeitschrift für Geschichte und Althertumskunde Ermlands 16 (1907): 345-555; Okulicz, Złotnictwo sakralne; Józefa Piskorska, Złotnictwo sakralne na Warmii w okresie baroku, t. 1 (Olsztyn: Warmińskie Wydawnictwo Diecezjalne, 2007), 21-43.

64 Zwracałem na to wielokrotnie uwagę, w szeregu prac, także w cytowanych na tych łamach; zob. też Tadeusz Chrzanowski i Marian Kornecki, Złotnictwo toruńskie. Studium o wyrobach cechu toruńskiego od wieku XIV do 1832 roku (Warszawa: PWN, 1988), 85-94. 
pływowych i miejscowych specjalistów się wyrównały, natomiast w XVIII stuleciu przeważali już złotnicy lokalnego pochodzenia ${ }^{65}$. Najwcześniej i najdobitniej proces ten uwidocznił się w małych ośrodkach, najpóźniej wystąpił w Gdańsku ${ }^{66}$. Jeszcze jedną prawidłowość można wywieść z obserwacji zachowanych dzieł (podkreślam: zachowanych bądź znanych z przekazów źródłowych; pierwotne proporcje wykonawcze mogły być inne, choć niezbyt odbiegające od poniższych szacunków). Otóż złotnicy w małych ośrodkach oprócz podstawowych naczyń i przedmiotów świeckich, głównie stołowych, takich jak lichtarze, kufle, kubki, misy, sztućce (ale już nie całe serwisy i zastawy stołowe), wykonywali przede wszystkim lub w równej mierze sprzęty kościelne. Z kolei w wielkich ośrodkach - Gdańsku i Królewcu - zdecydowanie dominowały przedmioty świeckie: naczynia stołowe, kredensowe, biżuteria. Wielkie miasta były przy tym w znacznie większym stopniu otwarte na szerokie wpływy zewnętrzne, także dzięki kontaktom politycznym i gospodarczym (handlowym). W konsekwencji przyciągały doświadczonych złotników, obytych w pracy w dużych centrach złotniczych - takich jak wspomniani wyżej Paul Hoffmann i Cornelius Vorwend w połowie XVI wieku w Królewcu czy Lorenz Hoffmann z Norymbergi w XVII stuleciu, a także współcześni mu Andreas I Mackensen z Delmenhorst, mistrz w Gdańsku, i Johann Christian Bierpfaff rodem z Dithmarschen, osiadły w Toruniu (obaj uprzednio złotnicy królewscy, czynni odpowiednio w Krakowie i Warszawie); szczególnie w Gdańsku liczni byli złotnicy obcego pochodzenia. Równolegle z tą asymilacją szła w parze samowystarczalność regionu w zakresie zaspokajania potrzeb własnych na naczynia kościelne; importy są nieliczne, sporadyczne, wręcz wyjątkowe, odróżniając tę prowincję od innych regionów Rzeczypospolitej. Więcej - złotnicy pruscy, zwłaszcza gdańscy, dostarczali swe wyroby do miejscowości geograficznie nieraz odległych od Prus, odpowiadając na zapotrzebowanie sporej części odbiorców, zwłaszcza z ziem koronnych Rzeczypospolitej.

Różnica w stosunku do czasów późnośredniowiecznych widoczna jest także w aspekcie odrębności poszczególnych centrów złotniczych (małe

65 Na podstawie: Arthur Semrau, „Die Bürgerlisten der Stadt Thorn aus dem 17. Jahrhunderte, 1: Die einheimischen Bürger, 2: Die ausländischen Bürger“, Mitteilungen des Coppernicus-Vereins für Wissenschaft und Kunst zu Thorn 27 (1919): 66-82; 28 (1920): 40-70; Czihak, Die Edelschmiedekunst.

66 Michał [F.] Woźniak, „Uwagi o pochodzeniu mistrzów i czeladników gdańskiego cechu złotniczego", Acta Universitatis Nicolai Copernici. Zabytkoznawstwo i Konserwatorstwo 25 (1994): 127-140. 
ośrodki, takie jak Malbork, Brodnica, Tylża, zależne były w dużej mierze od sąsiednich większych miast,). Obfita w XVII wieku wytwórczość królewiecka, pokrewna gdańskiej i hamburskiej, o dobrych walorach plastycznych, choć ze skłonnością do uogólnienia formy na niekorzyść precyzji detalu, słabła w XVIII wieku, poddana konkurencji coraz bardziej prężnych centrów w Sztokholmie, Rydze, Revalu, a także nowego w St. Petersburgu. Złotnicy czynni w Elblągu nie wypracowali - jako reprezentanci pewnego lokalnego środowiska artystycznego - własnej formuły, a styl tego ośrodka był „heterogeniczny”. Toruń pozostawał introwertyczny, pielęgnując własne dokonania i przeżyty rozwój, nie wykraczając poza europejską przeciętność, ale też budując własne, wyraziste oblicze. W tym mieście bowiem najsilniej uwidocznił się nurt retrospektywny, postgotycki, w podobnym czasie wystąpiła także, przez sięgnięcie do italskiego wzorca renesansowego kielicha, cecha awangardowa. Te dwa zjawiska były obce Gdańskowi. Wyroby czynnych tam złotników, otwartych na różne kierunki inspiracji, wykazują się największą różnorodnością pod względem budowy i formy: są wśród nich zarówno przedmioty powściągliwe, ascetyczne w kształcie (te formy w ciekawy sposób realizowano w Toruniu!), jak i - przeważające - plastyczne, bogato członowane i opracowane. W najwyższym stopniu właśnie w Gdańsku uskuteczniło się i ujawniło formalne mistrzostwo, wirtuozeria wykonawcza. Patrząc od wewnątrz, z oddolnego, pruskiego punktu widzenia, dostrzega się istotne różnice w stylu i charakterze wytwórczości złotniczej w poszczególnych ośrodkach. Jednak przy oglądzie zewnętrznym nie sposób przeoczyć istnienia pewnych cech wspólnych. W pierwszym rzędzie zaliczyć do nich trzeba brak przesady i epatowania efektownością, nadmiarem dekoracji, przeładowaniem formalnym; oszczędność - wobec praktycznej rezygnacji z kameryzowania kamieniami szlachetnymi i ich imitacjami oraz wprowadzania barwnych efektów emaliowanych partii; równowagę pomiędzy podstawową strukturą przedmiotu a zastosowaną dekoracją; powściągliwość w efektach plastycznych na rzecz umiaru i rozwagi. 


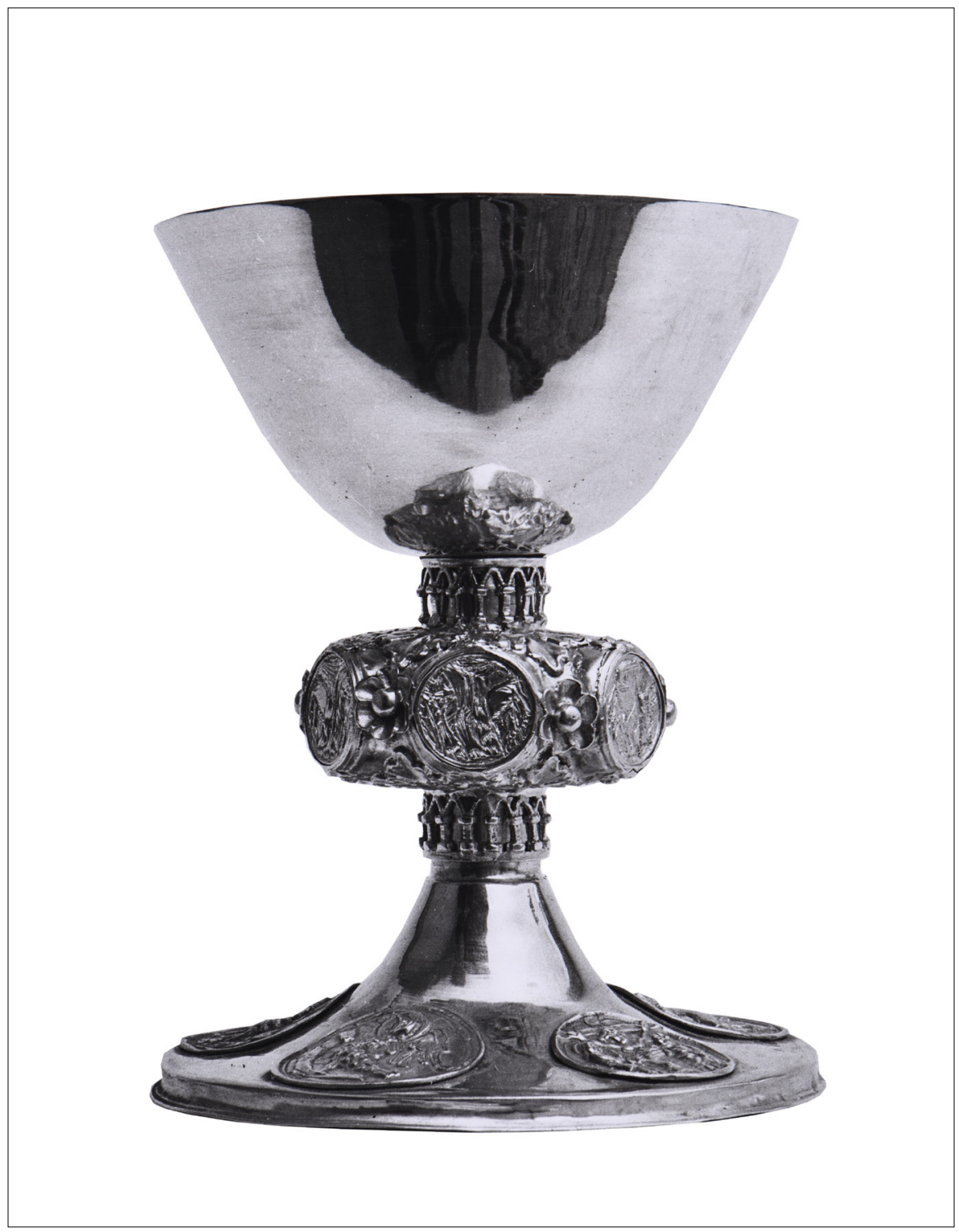

1. Nieznany złotnik pruski (?), Kielich, srebro złocone, ok. 1300. Stary Targ, kościół par. pw. św. Szymona i Judy Tadeusza. Fot. W. Górski 


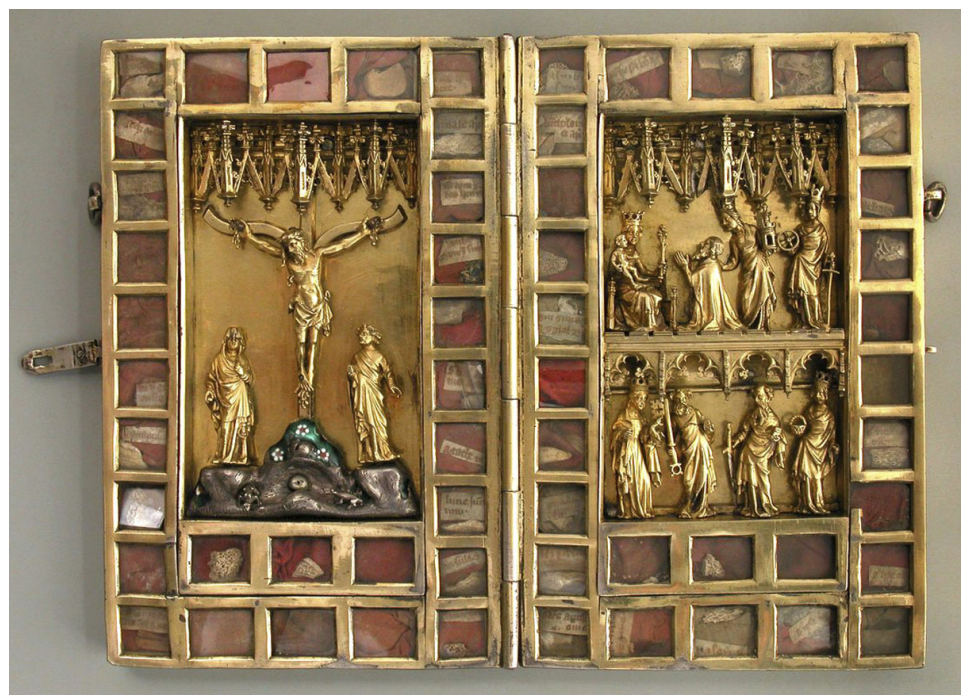

2. Nieznany złotnik pruski (elbląski?), Relikwiarz - dyptyk (strona wewnętrzna), srebro częściowo złocone, emalia, szkło, jedwab, ok. 1388. Warszawa, Muzeum Wojska Polskiego, nr inw. MWP 129; wcześniej: Elbląg, kościół zamkowy (konwentualny), od 1411 (lub krótko po) Gniezno, katedra, od 1823 Malbork, zbiory zamkowe, od 1946 Warszawa. Fot. Lech Okoński

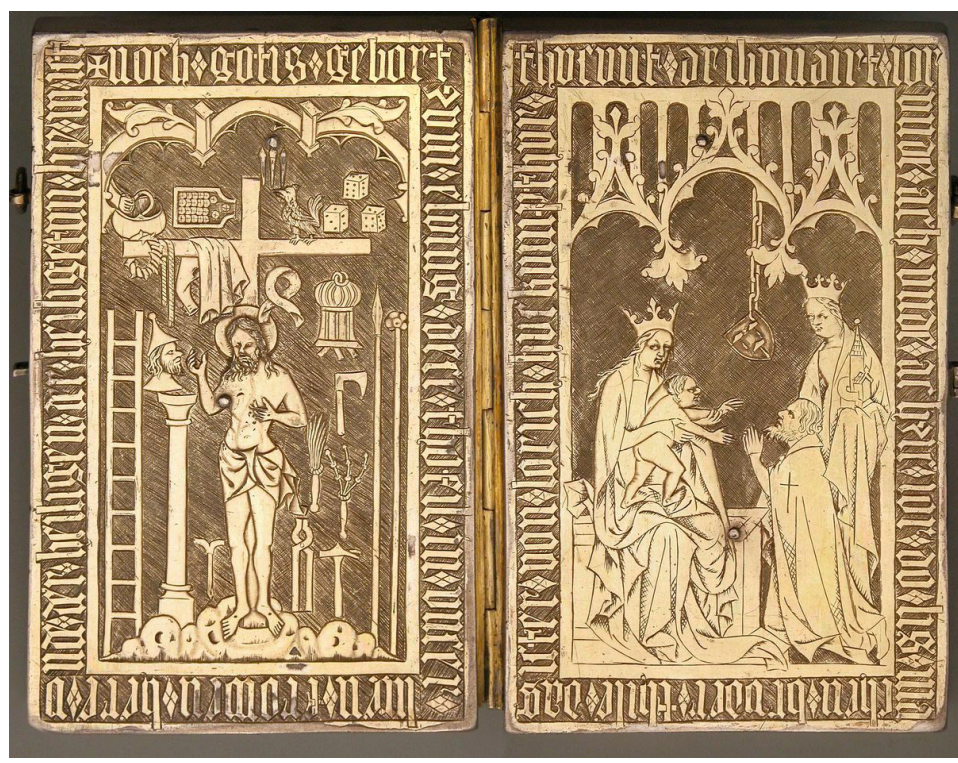

3. Nieznany złotnik pruski (elbląski?), Relikwiarz - dyptyk (strona zewnętrzna), srebro częściowo złocone, ok. 1388. Warszawa, Muzeum Wojska Polskiego, nr inw. MWP 129. Fot. Lech Okoński 


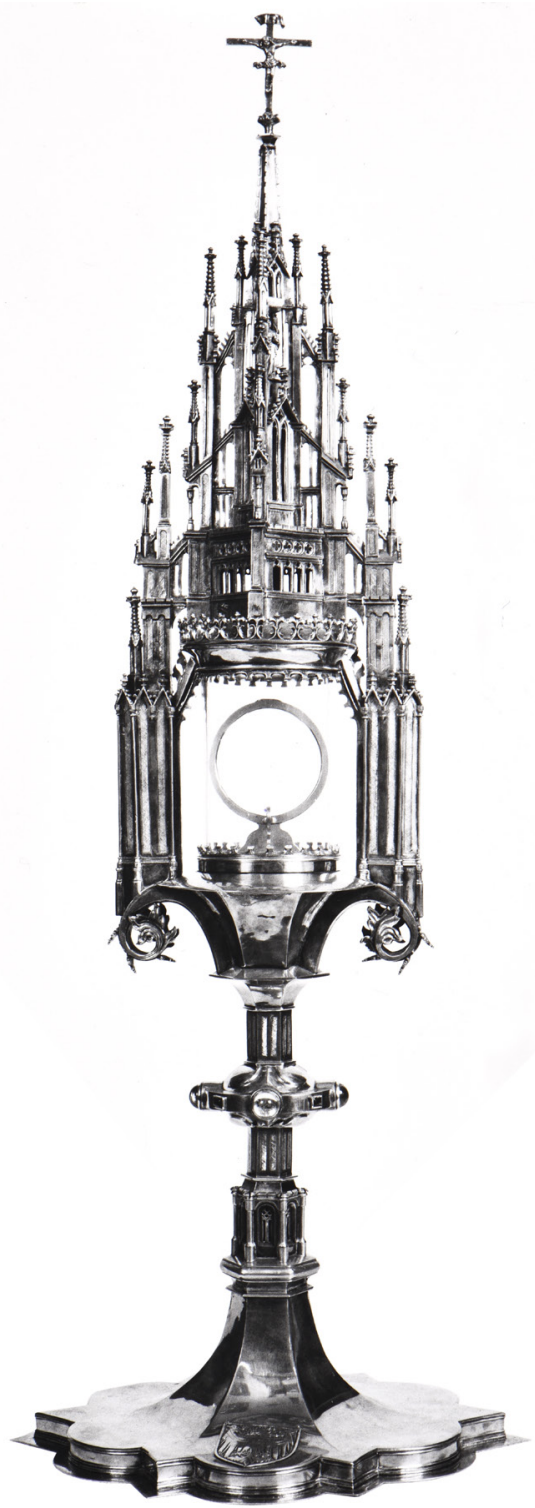

4. Nieznany złotnik pruski (gdański?), Monstrancja eucharystyczna, srebro złocone, kryształy górskie, szkło, ok. 1400; przekształcona w poł. XVIII w., restaurowana w zakładzie Josepha Franza Osthuesa, Münster 1897-1898. Poznań, kościół par. pokarmelicki pw. Bożego Ciała (ob. eksponowana w Muzeum Archidiecezjalnym w Poznaniu). Fot. W. Górski 


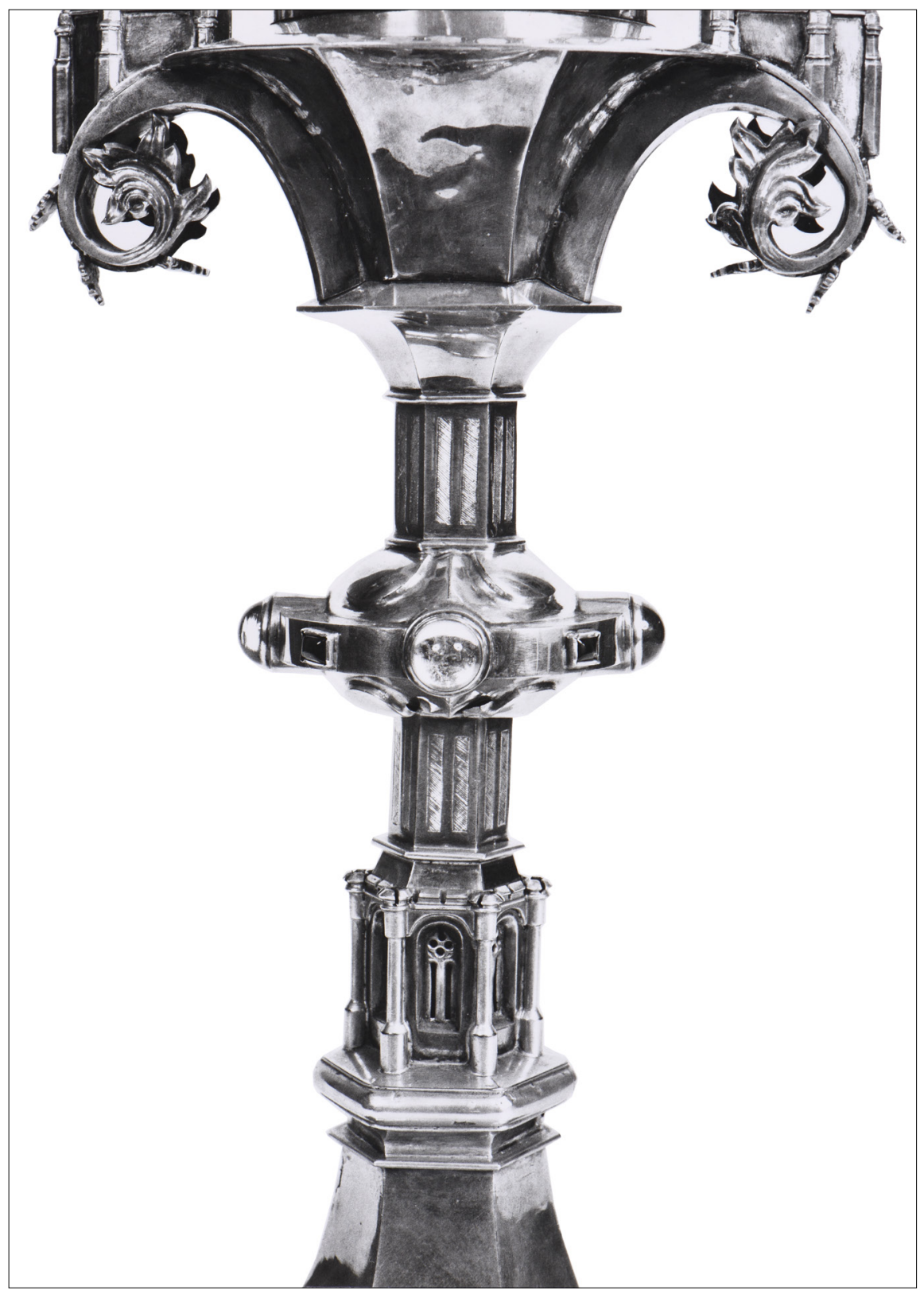

4a. Monstrancja eucharystyczna, fragment: trzon z nodusem. Fot. W. Górski 


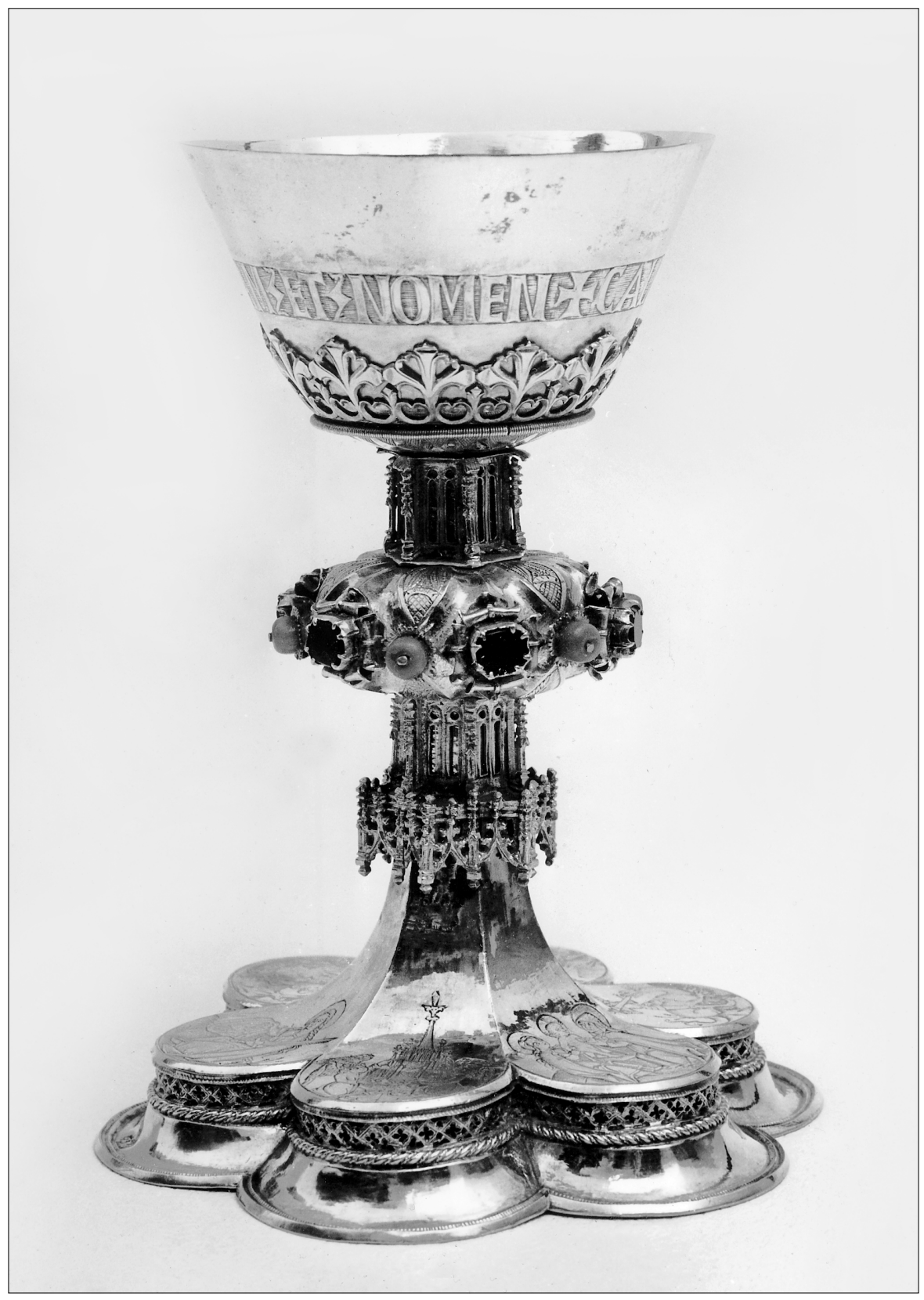

5. Złotnik elbląski (Dionysius Freymann?), Kielich, srebro złocone, kamienie szlachetne i korale (nowe), ok. 1500. Gniezno, Muzeum Archidiecezji Gnieźnieńskiej; pochodzi z kościoła szpitalnego, następnie par. pw. Bożego Ciała w Elblągu. Fot. W. Górski 


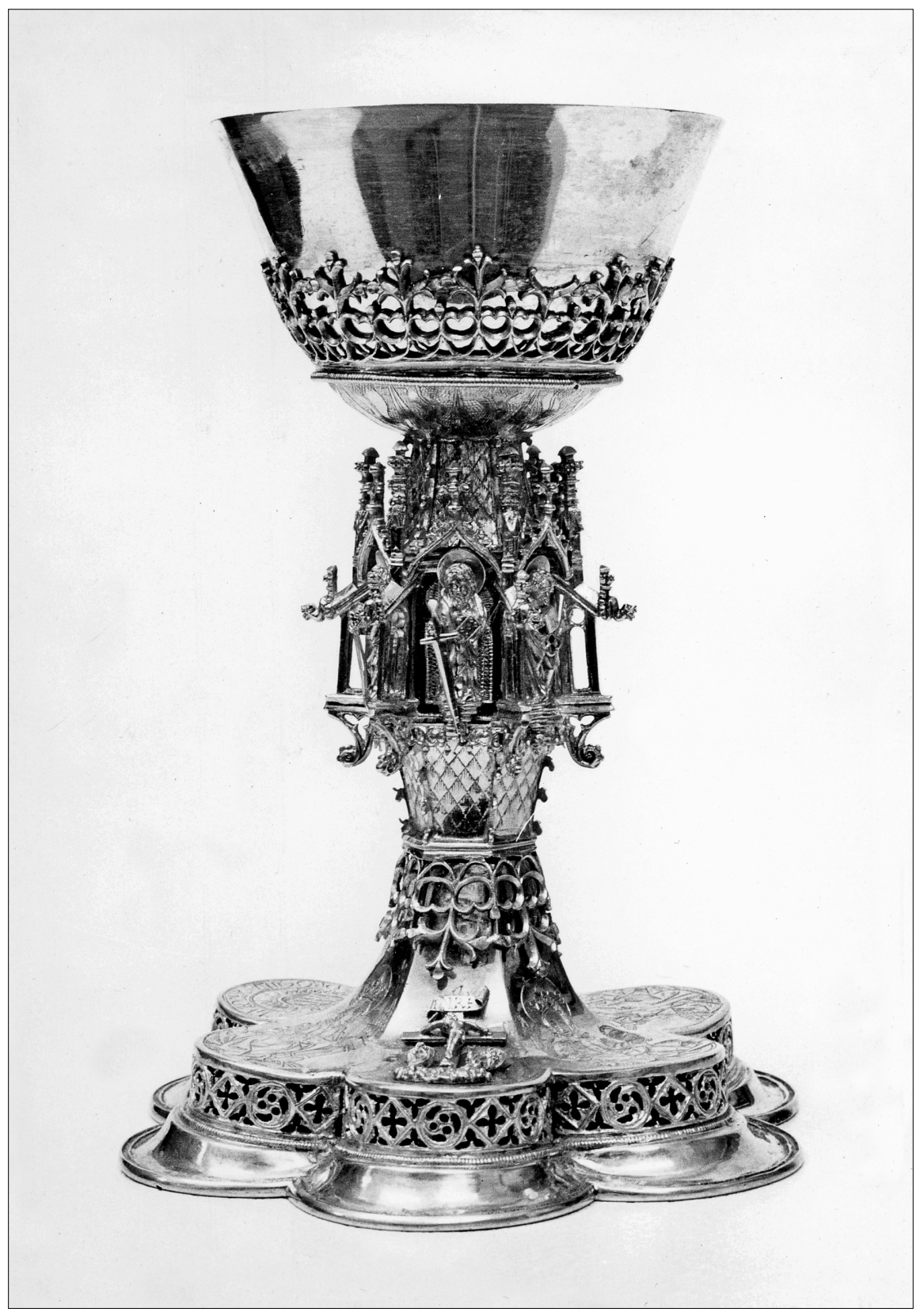

6. Złotnik toruński, Kielich, srebro częściowo złocone, 1508-1514. Lubawa, kościół par. pw. Nawiedzenia NMP i św. Anny. Fot. W. Górski 


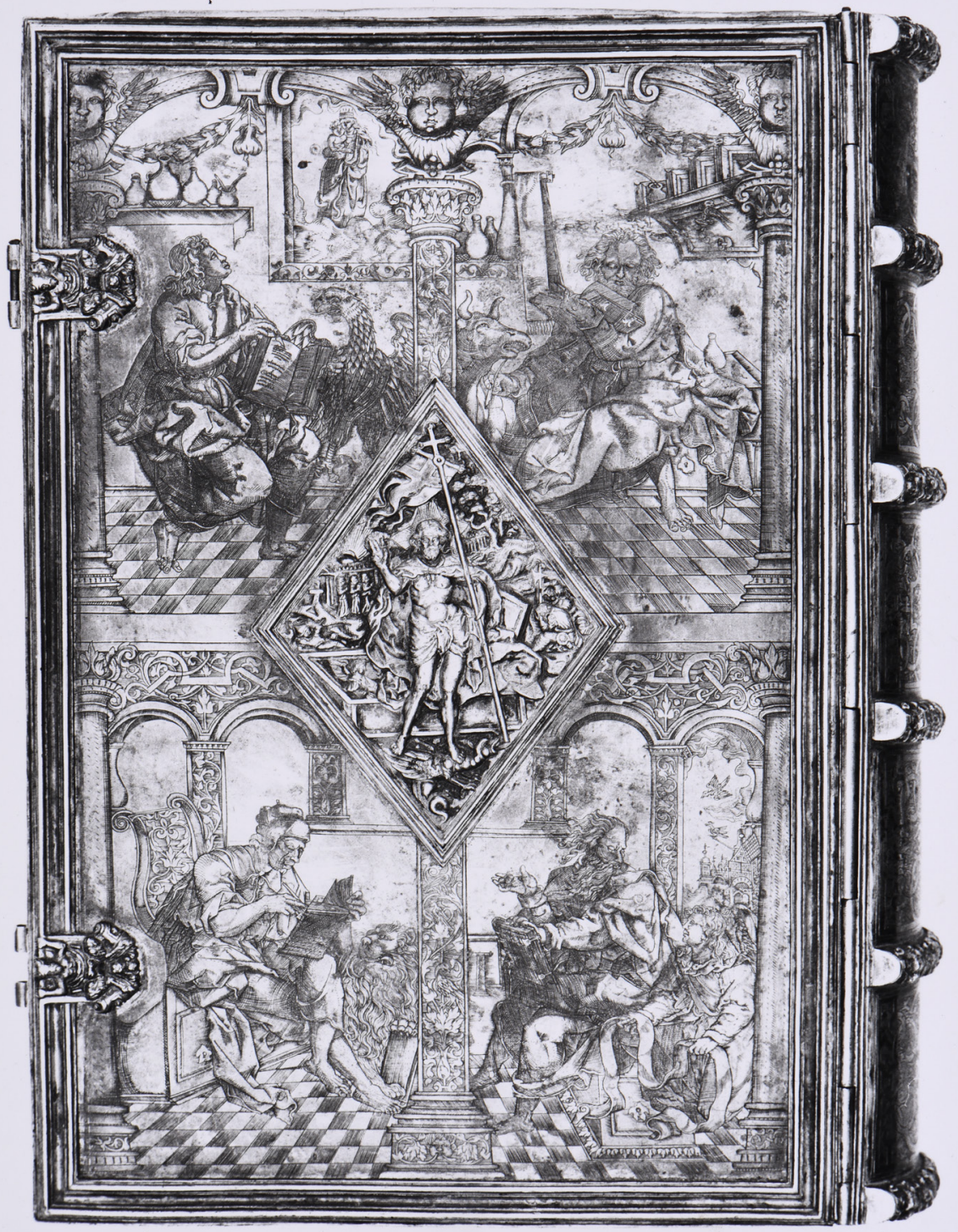

7. Paul Hoffmann, Oprawa księgi (okładzina tylna), srebro, Królewiec 1555. Toruń, Biblioteka Uniwersytecka, Ob.6.III.716; przed 1945 Staats- und Universitätsbibliothek in Königsberg, Fol. 7. Fot. W. Górski 


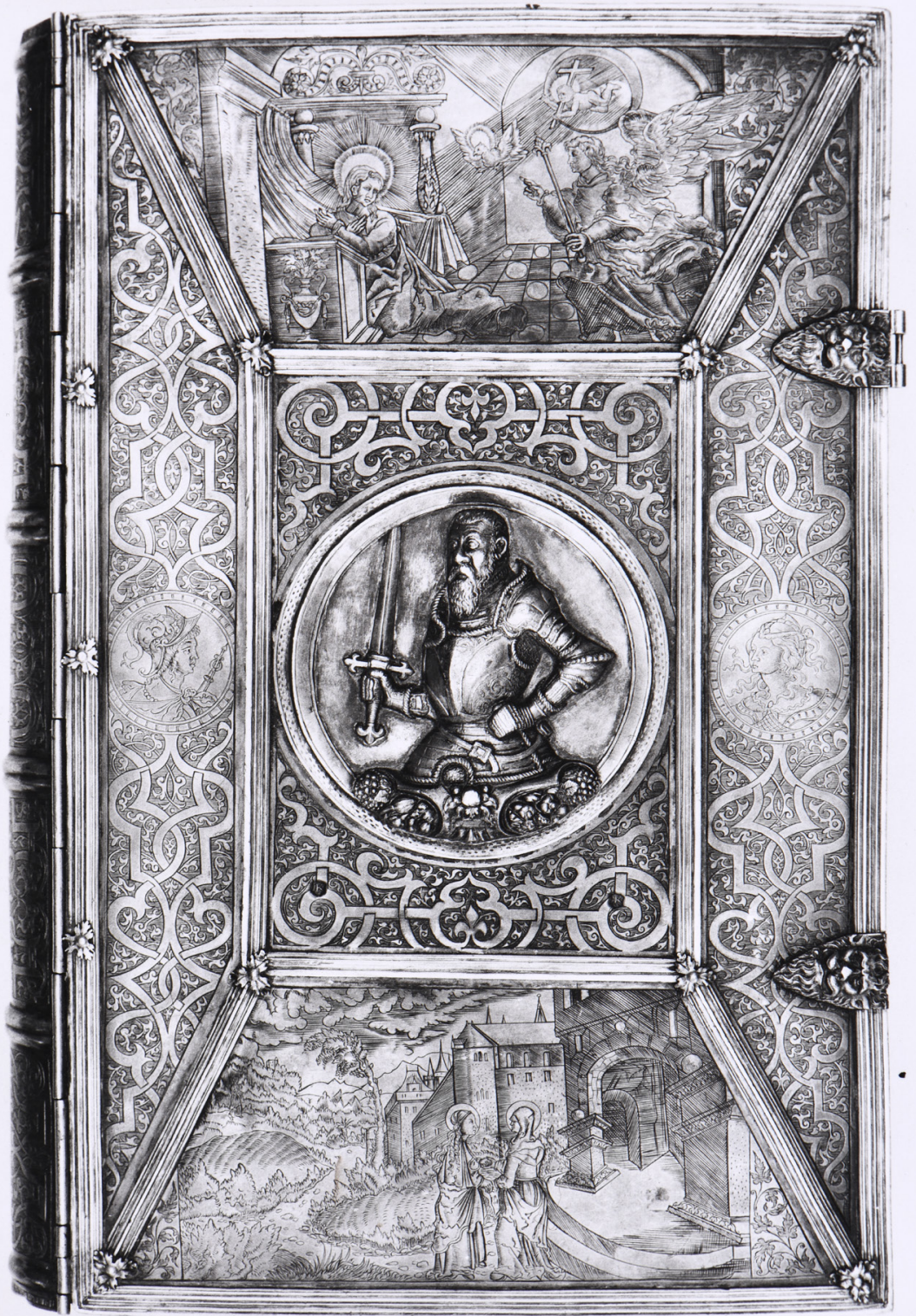

8. Hieronymus Kösler, Oprawa księgi (okładzina przednia), srebro, Królewiec ok. 1555. Toruń, Biblioteka Uniwersytecka, Ob.6.III.711; przed 1945 Staats- und Universitätsbibliothek in Königsberg, Fol. 4. Fot. W. Górski 


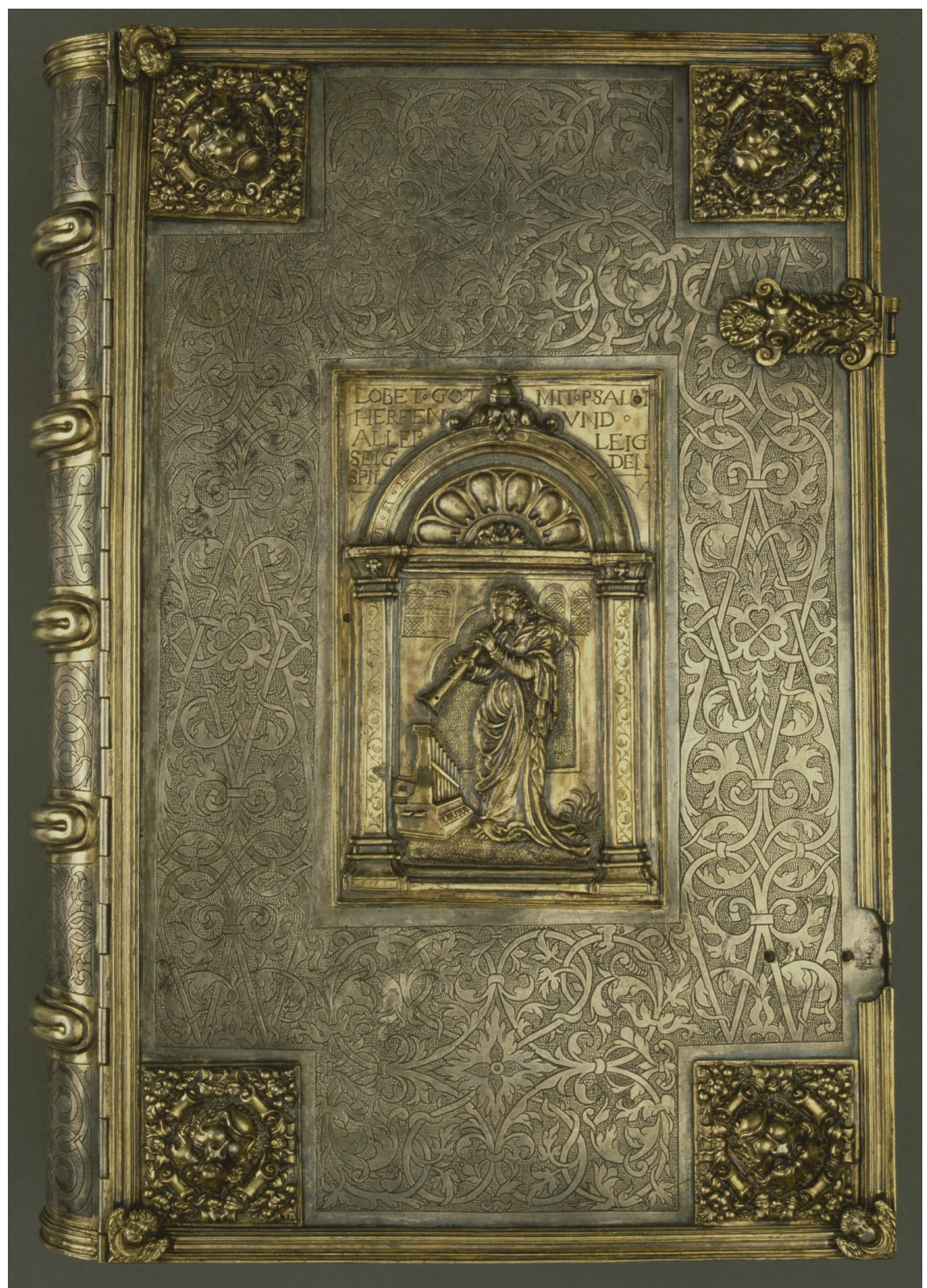

9. Gerhard Lentz, Oprawa księgi (okładzina tylna), srebro, Królewiec 1555. Toruń, Biblioteka Uniwersytecka, Ob.6.III.706; przed 1945 Staats- und Universitätsbibliothek in Königsberg, Fol. 13. Fot. W. Górski 


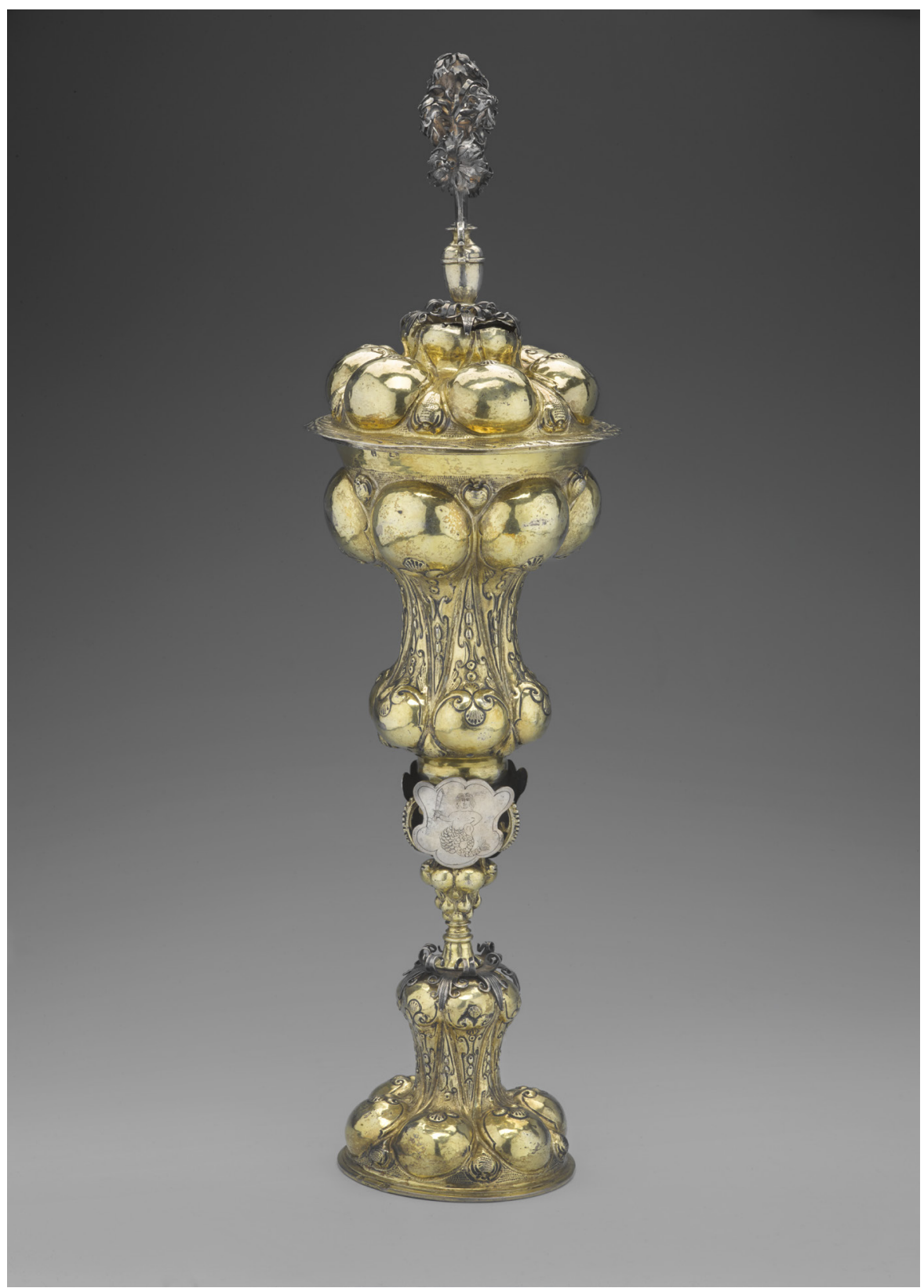

10. Zacharias Dersau, Puchar puklowany / wilkom bractwa kupieckiego Starego Miasta Warszawy, srebro złocone, Gdańsk, pocz. XVII w. Warszawa, Muzeum Narodowe, nr inw. 180468 MN. Fot. P. Ligier 


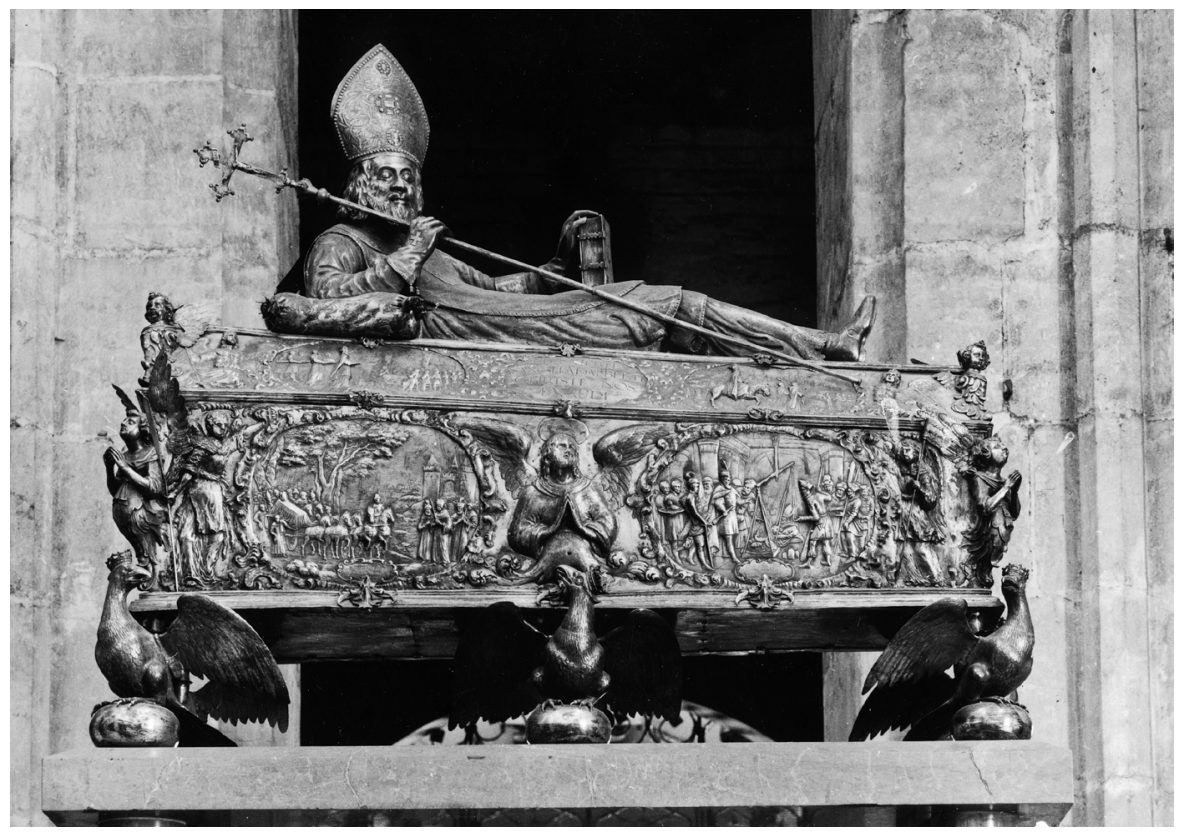

11. Peter van der Rennen, Relikwiarz sarkofagowy św. Wojciecha, srebro, Gdańsk 1662. Gniezno, kościół katedralny pw. Wniebowzięcia NMP i św. Wojciecha. Fot. W. Górski 


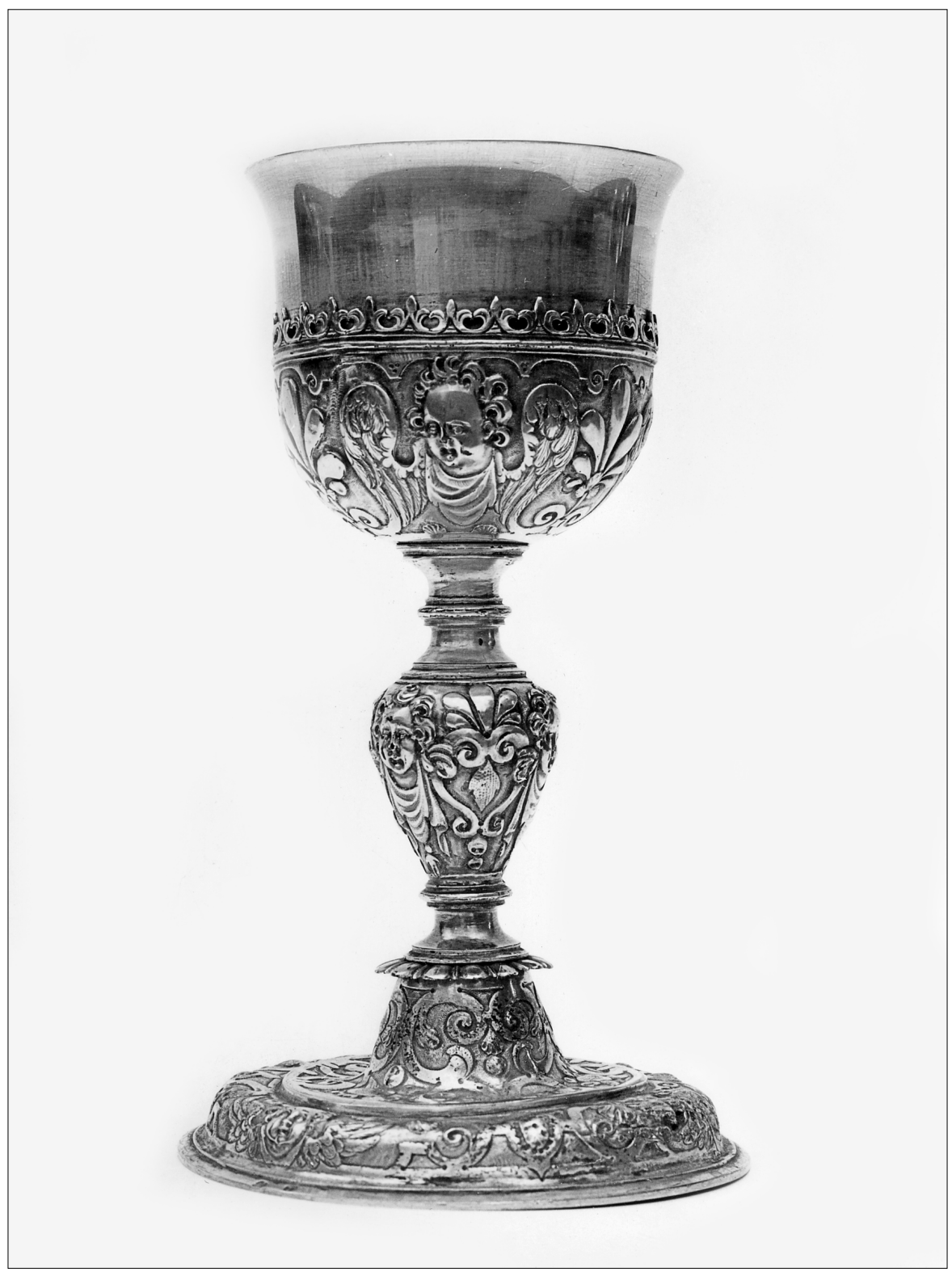

12. Albrecht I Weimmer, Kielich, srebro złocone, Toruń ok. 1600. Toruń, kościół par. pw. Wniebowzięcia NMP; pochodzi z kościoła przedmiejskiego pw. św. Wawrzyńca. Fot. W. Górski 


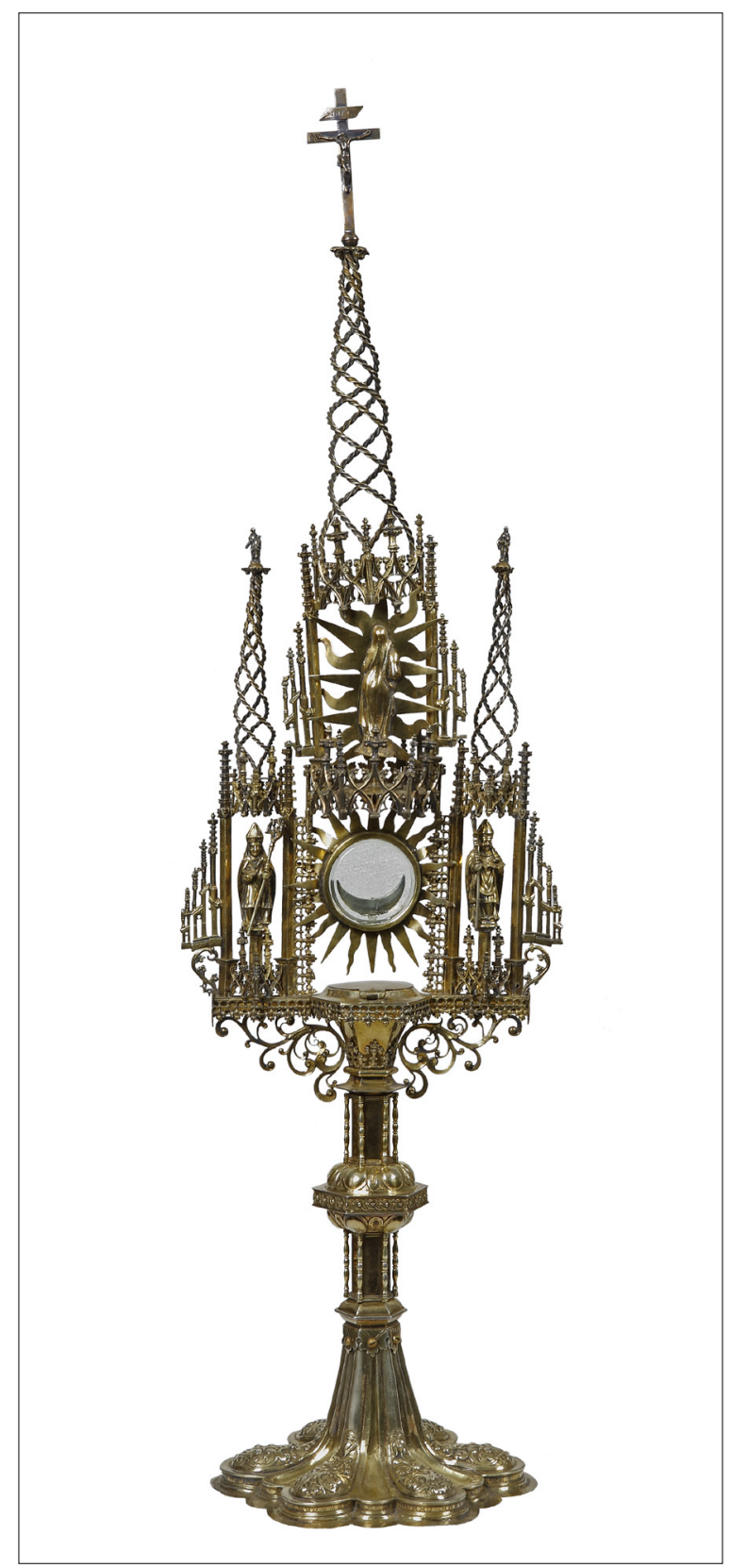

13. Nickel II Gerlach, Monstrancja eucharystyczna, srebro częściowo złocone, Toruń 1612. Chełmża, kościół konkatedralny pw. Trójcy Świętej. Fot. A. Skowroński 


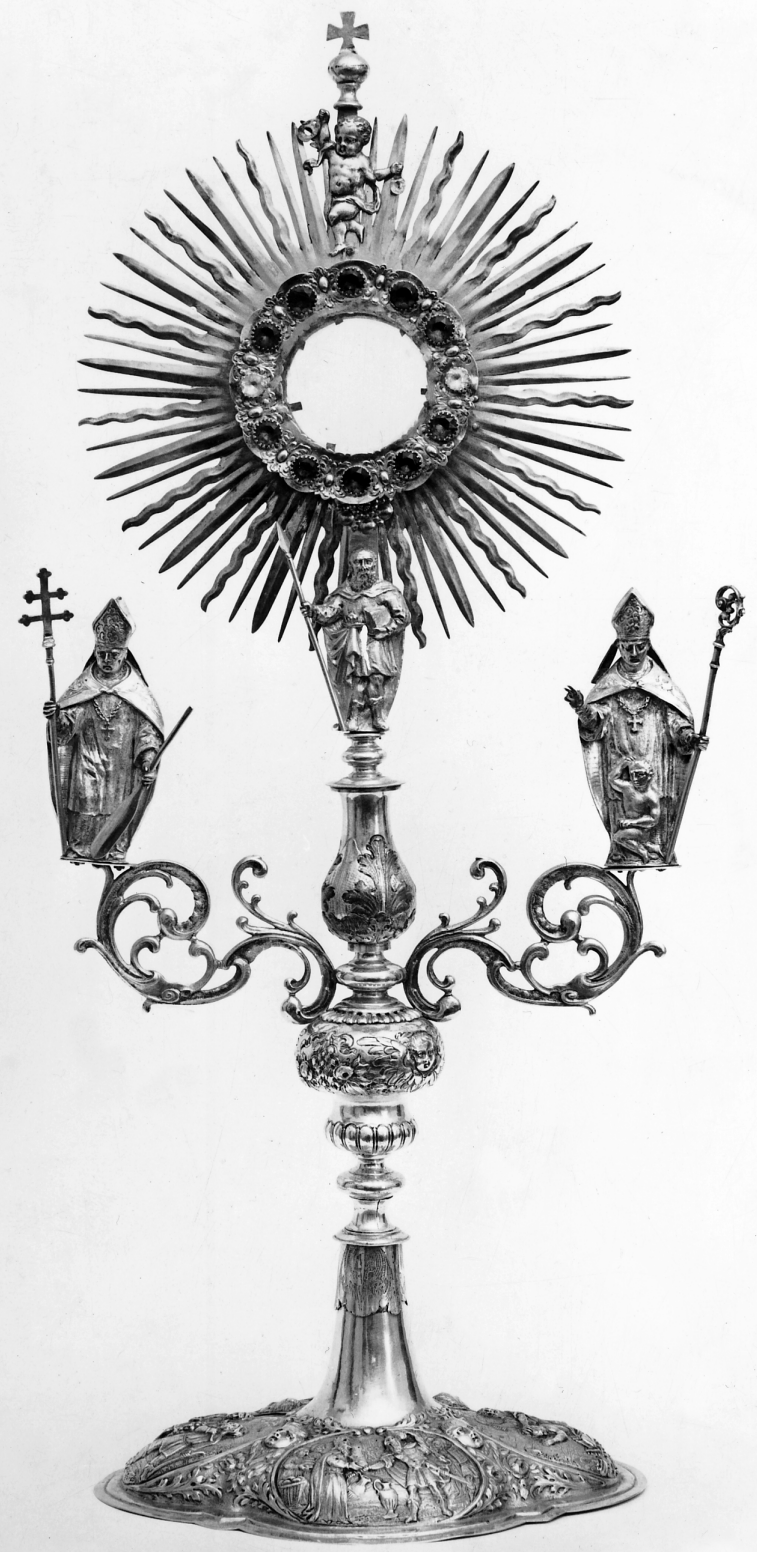

14. Jakob Weintraub, Monstrancja eucharystyczna, srebro częściowo złocone, Toruń 1720 (figurki na ramionach pochodzą z wcześniejszej monstrancji retabulowej, 1621). Bądkowo, kościół par. pw. św. Mateusza. Fot. W. Górski 


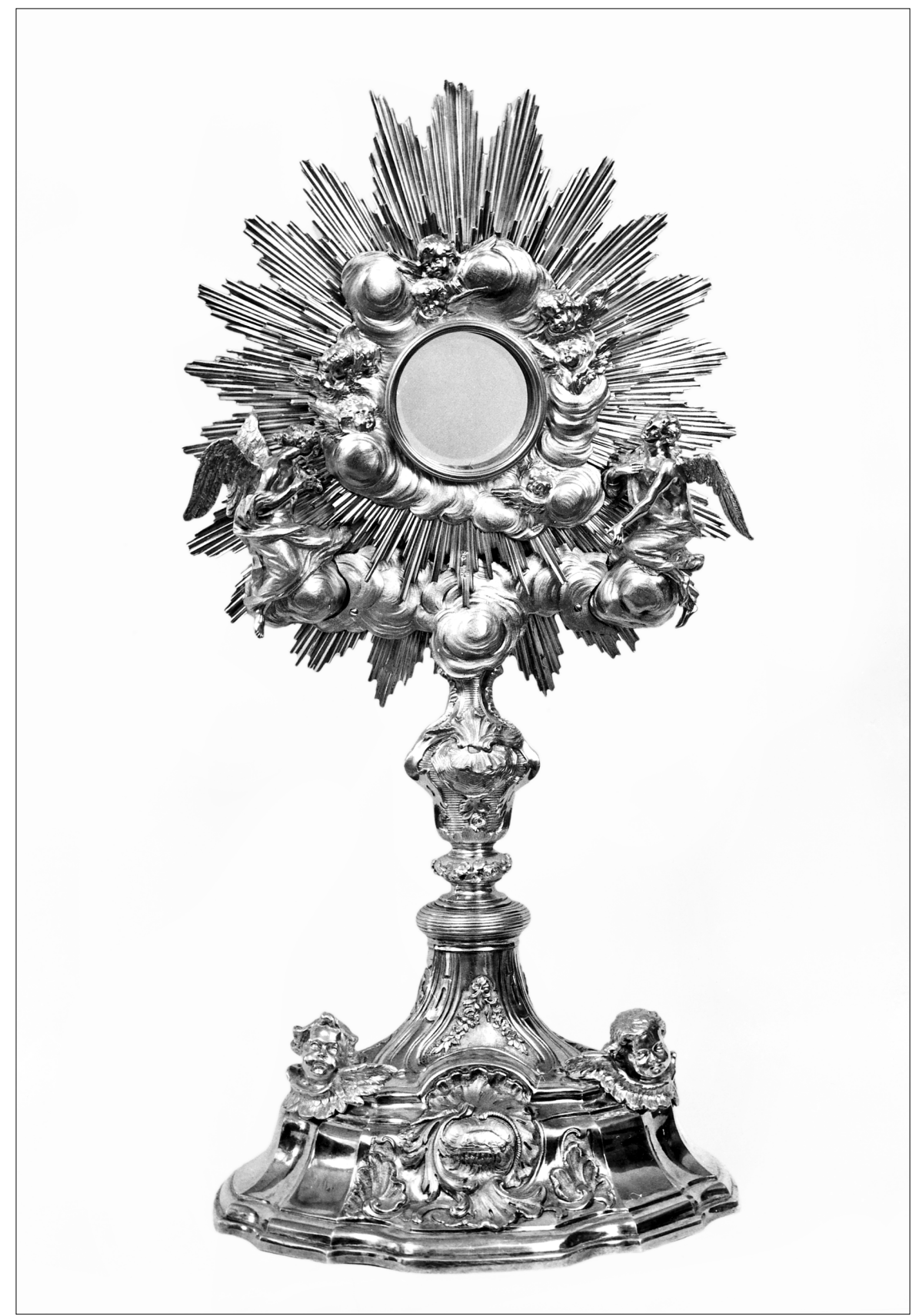

15. Johann Gottfried Schlaubitz, Monstrancja eucharystyczna, srebro złocone, Gdańsk 1759-1762. Olsztyn-Redykajny, Wyższe Seminarium Duchowne Hosianum; pochodzi z kościoła par. pw. św. Katarzyny w Braniewie. Fot. W. Górski 


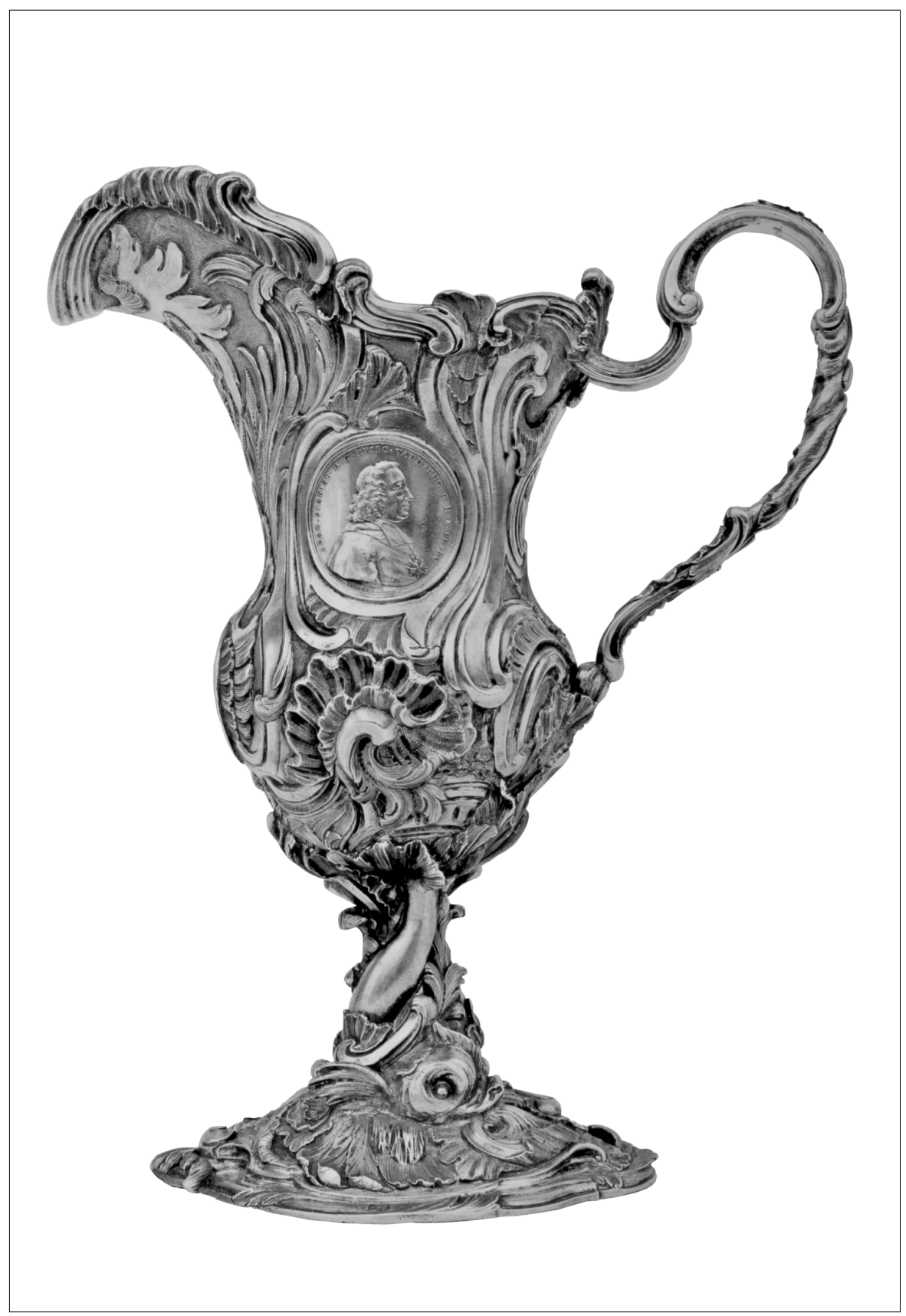

16. Johann Gottfried Schlaubitz, Dzban lavabo, srebro, Gdańsk 1752. Olsztyn, Kuria Arcybiskupia; pochodzi z kościoła katedralnego pw. Wniebowzięcia NMP we Fromborku. Fot. W. Górski 


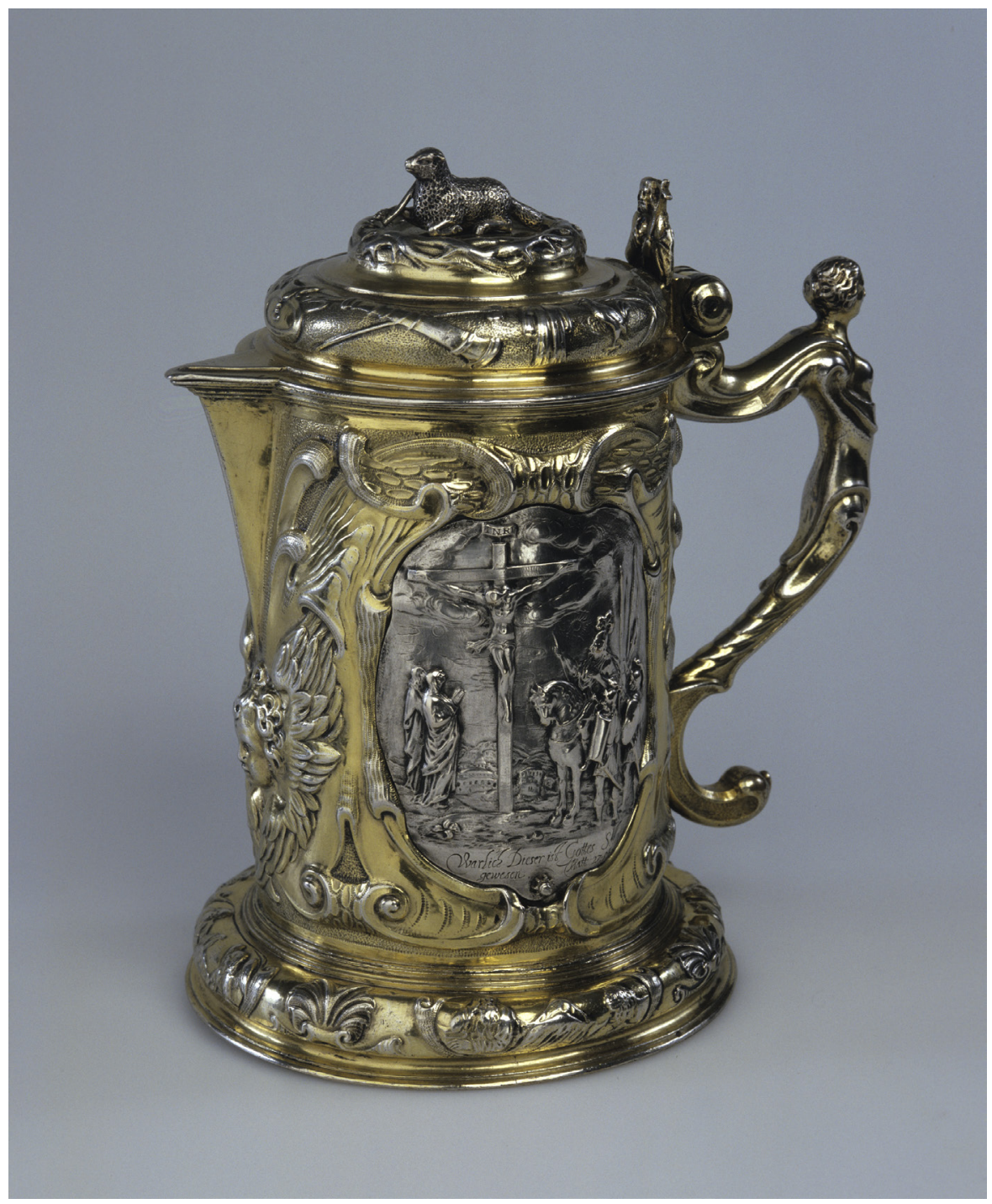

17. Andreas I Mackensen, Dzban liturgiczny (komunijny), srebro częściowo złocone, Gdańsk ok. 1644-1646. Kraków, Zamek Królewski na Wawelu. Państwowe Zbiory Sztuki, nr inw. 4205 (pochodzenie nieznane). Copyright @ Zamek Królewski na Wawelu. Fot. S. Michta 


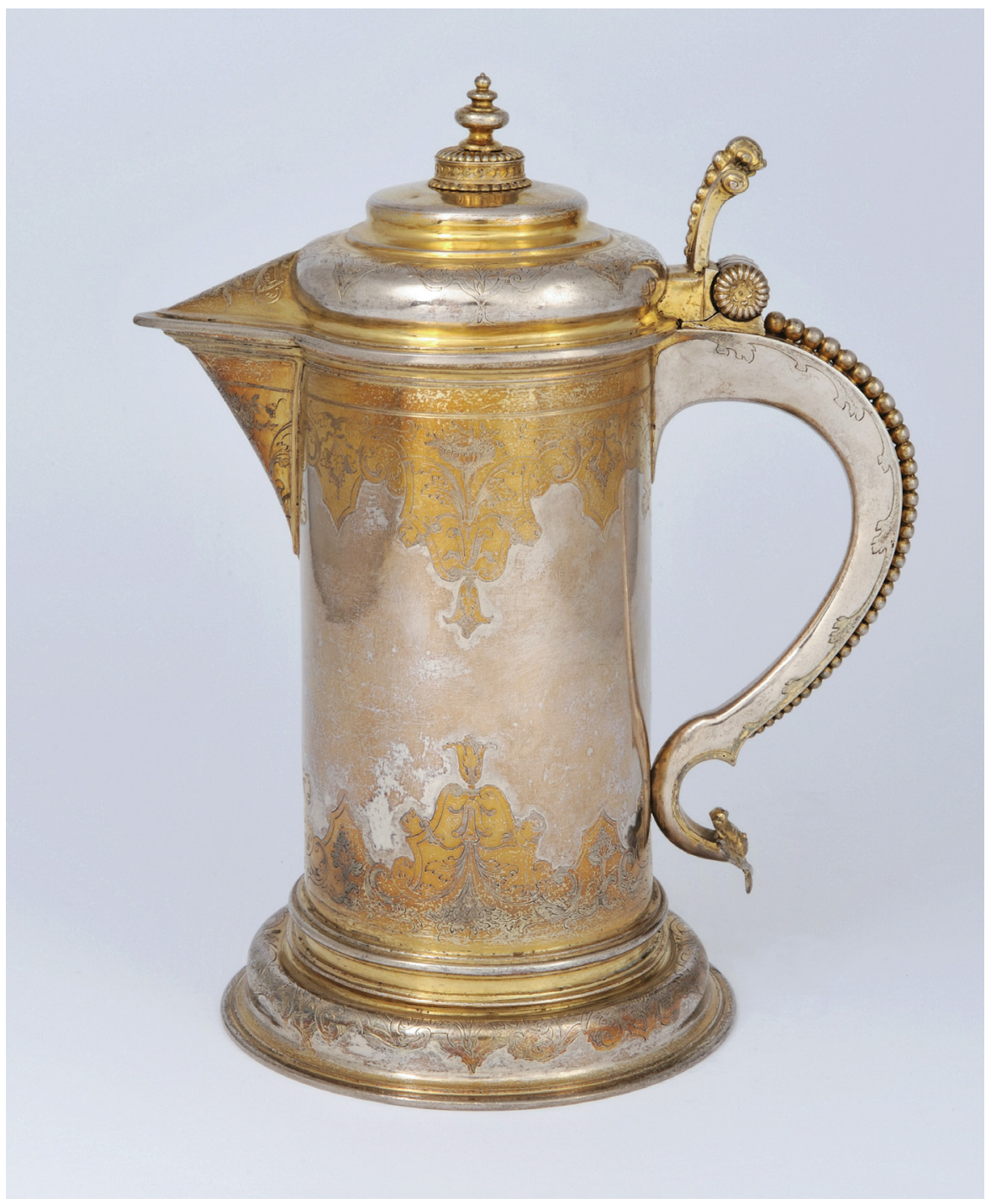

18. Michael Dietrich, Dzban liturgiczny (komunijny), srebro częściowo złocone, Gdańsk 1709. Gdańsk, Muzeum Narodowe, nr inw. MNG/SD/118/MT; pochodzi ew. z kościoła par. pw. św. Barbary. Fot. Muzeum 


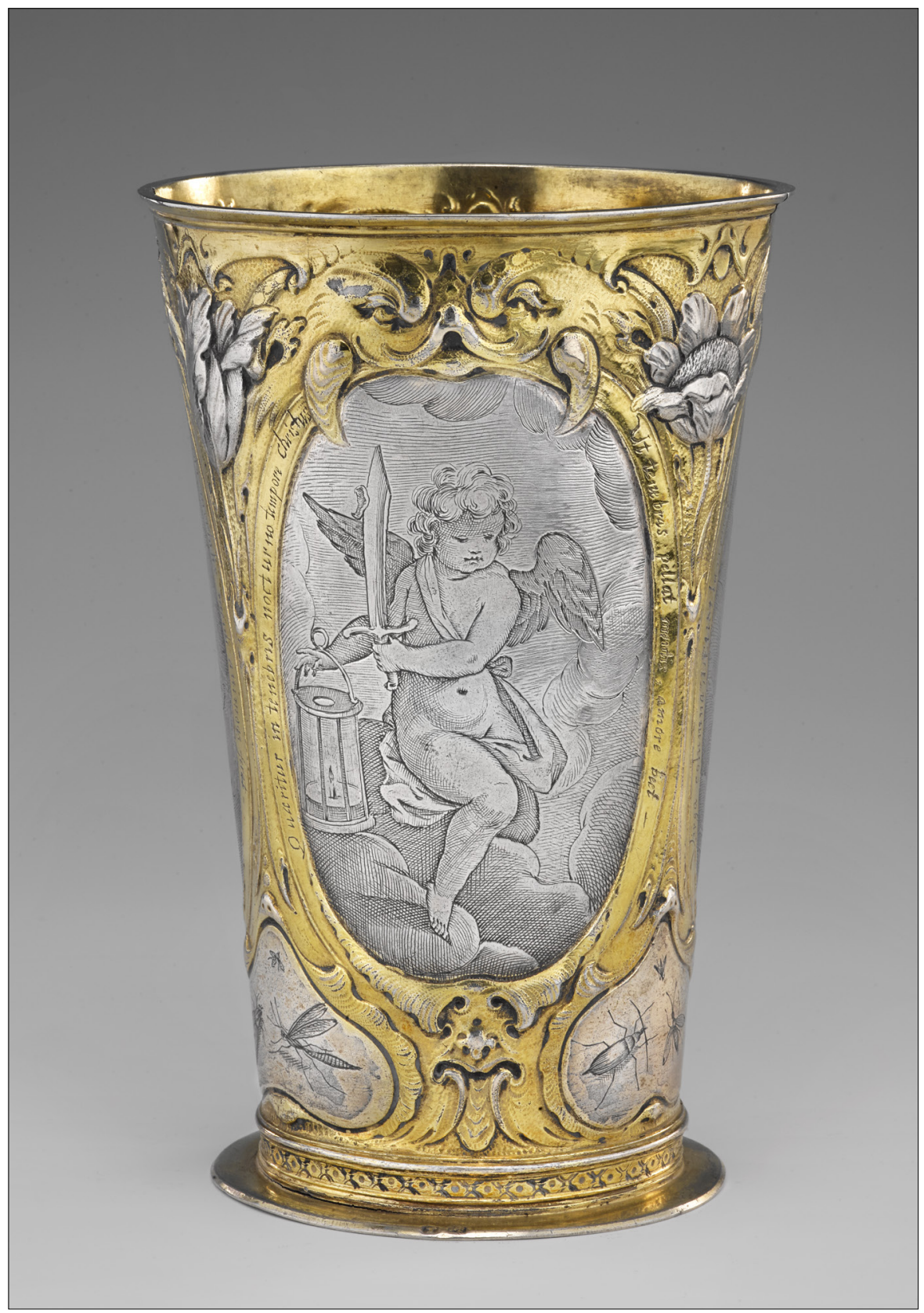

19a. Johann Christian Bierpfaff, Kubek, srebro, Toruń ok. 1660. Warszawa, Muzeum Narodowe, nr inw. 128474 MN; zakup 1946 od Tadeusza Wierzejskiego. Fot. W. Górski 


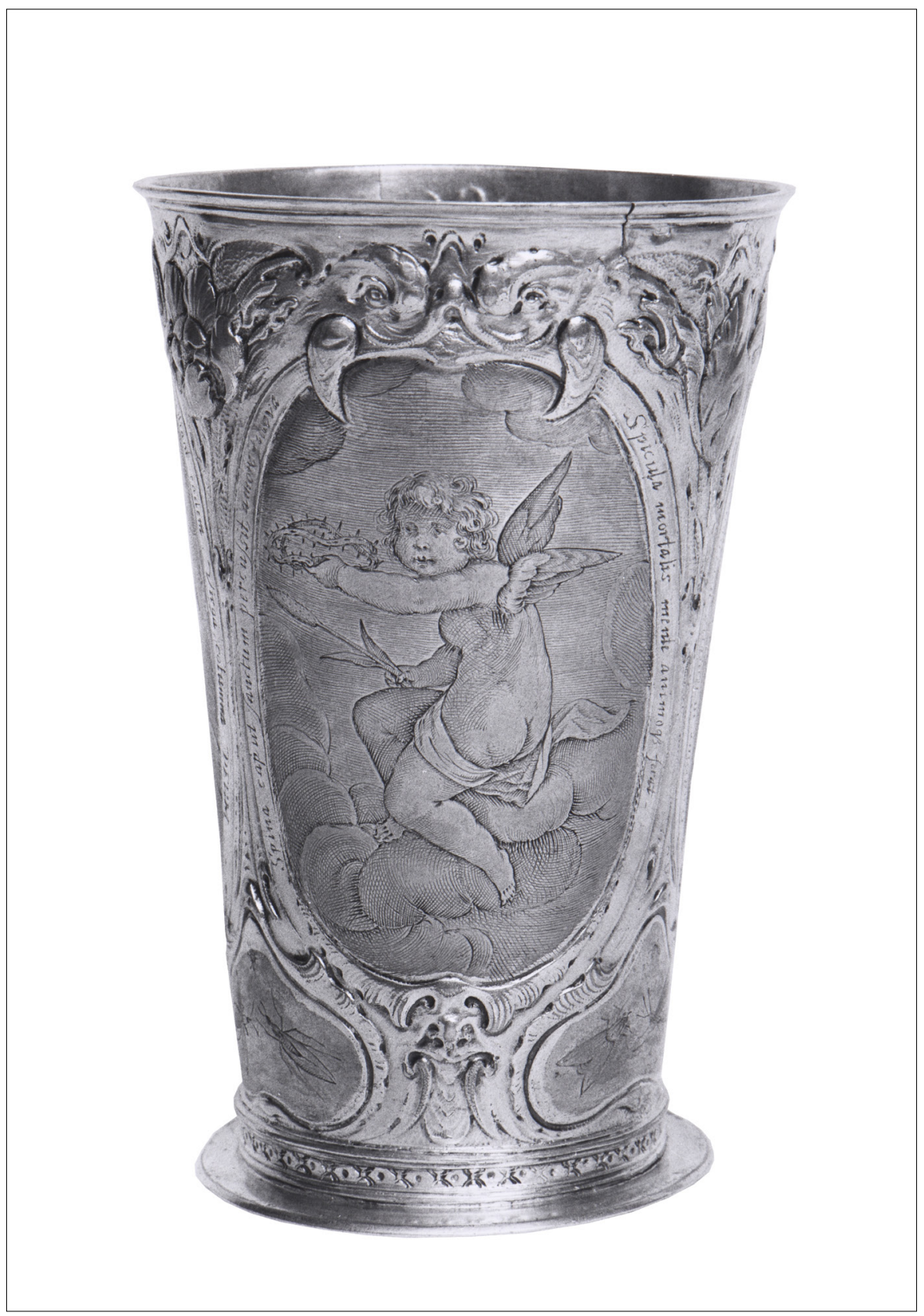

19b. Johann Christian Bierpfaff, Kubek, srebro, Toruń ok. 1660. Warszawa, Muzeum Narodowe, nr inw. 128474 MN; zakup 1946 od Tadeusza Wierzejskiego. Fot. P. Ligier 


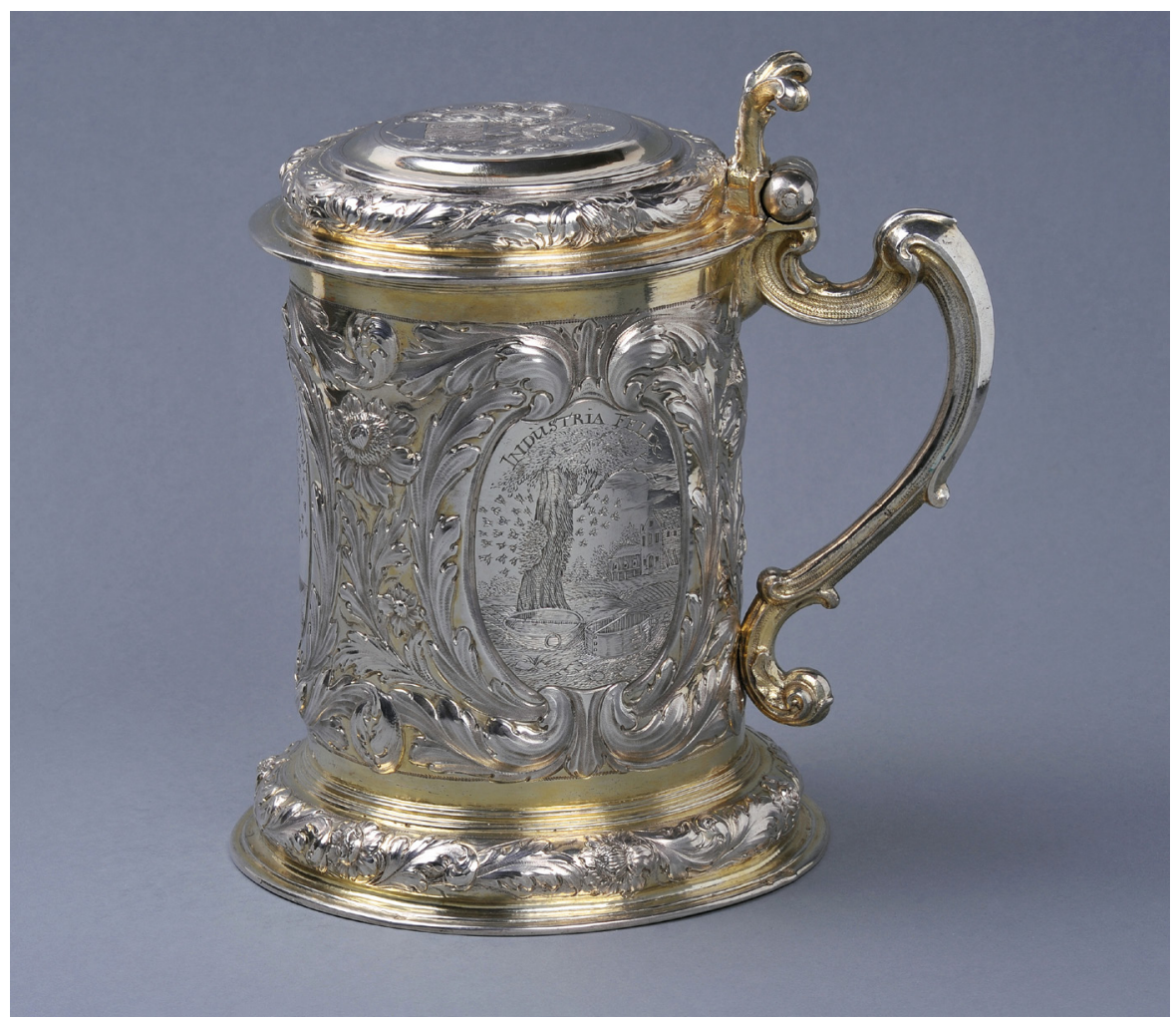

20. Johann Gottfried Holl, Kufel, srebro złocone, Gdańsk ok. 1685. Gdańsk, Muzeum Narodowe, nr inw. MNG/SD/100/MT; wcześniej w posiadaniu rodziny Zorpele. Fot. Muzeum 


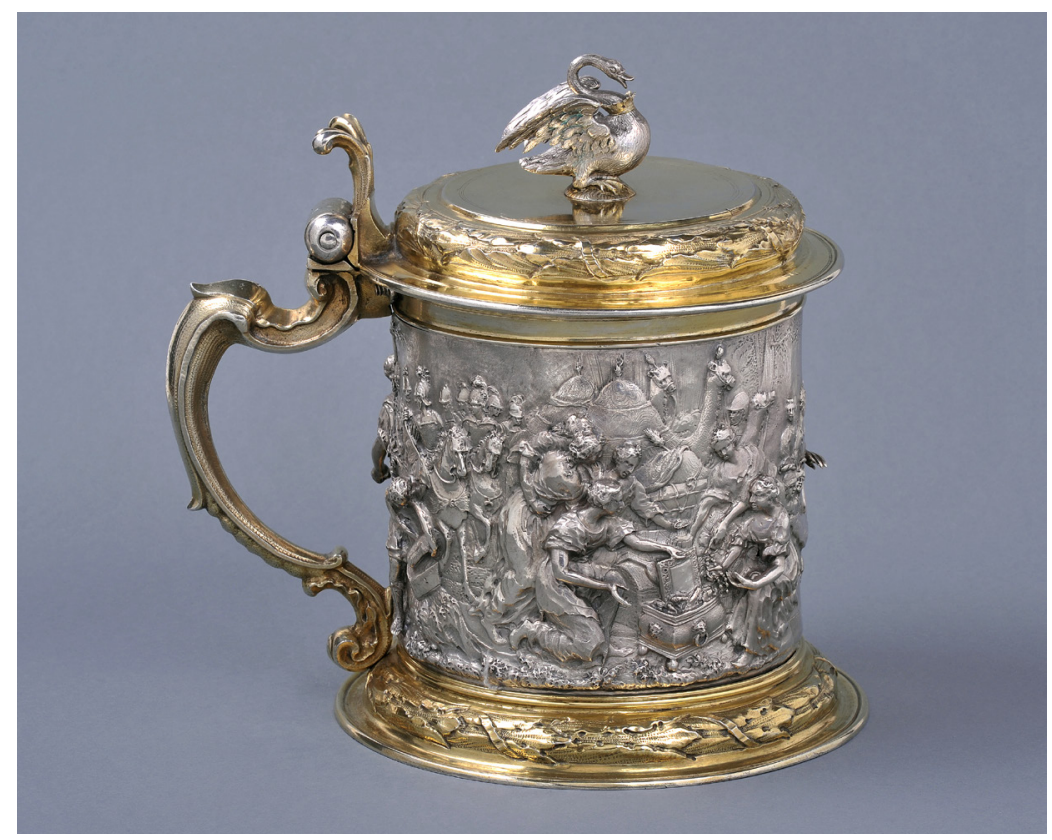

a)

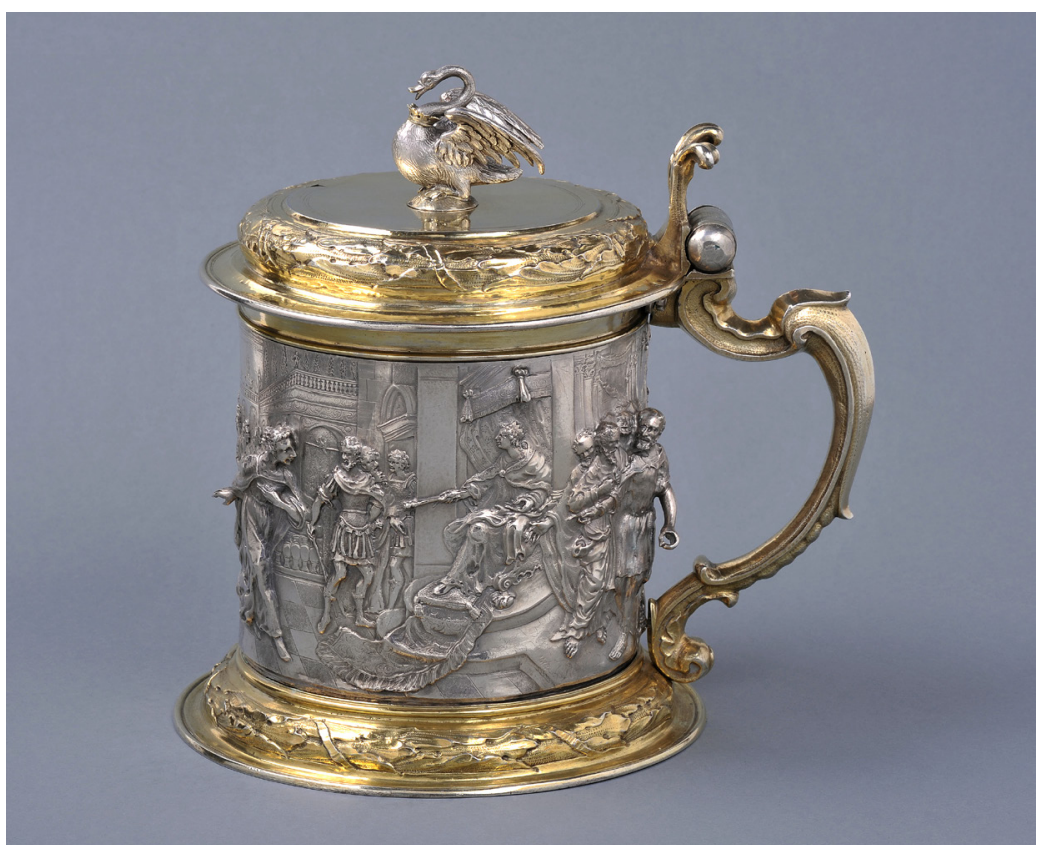

b)

21. a-b. Benedict Clausen, Kufel, srebro częściowo złocone, Gdańsk 1689-1699. Gdańsk, Muzeum Narodowe, nr inw. MNG/SD/97/MT (pochodzenie nieznane). Fot. Muzeum 


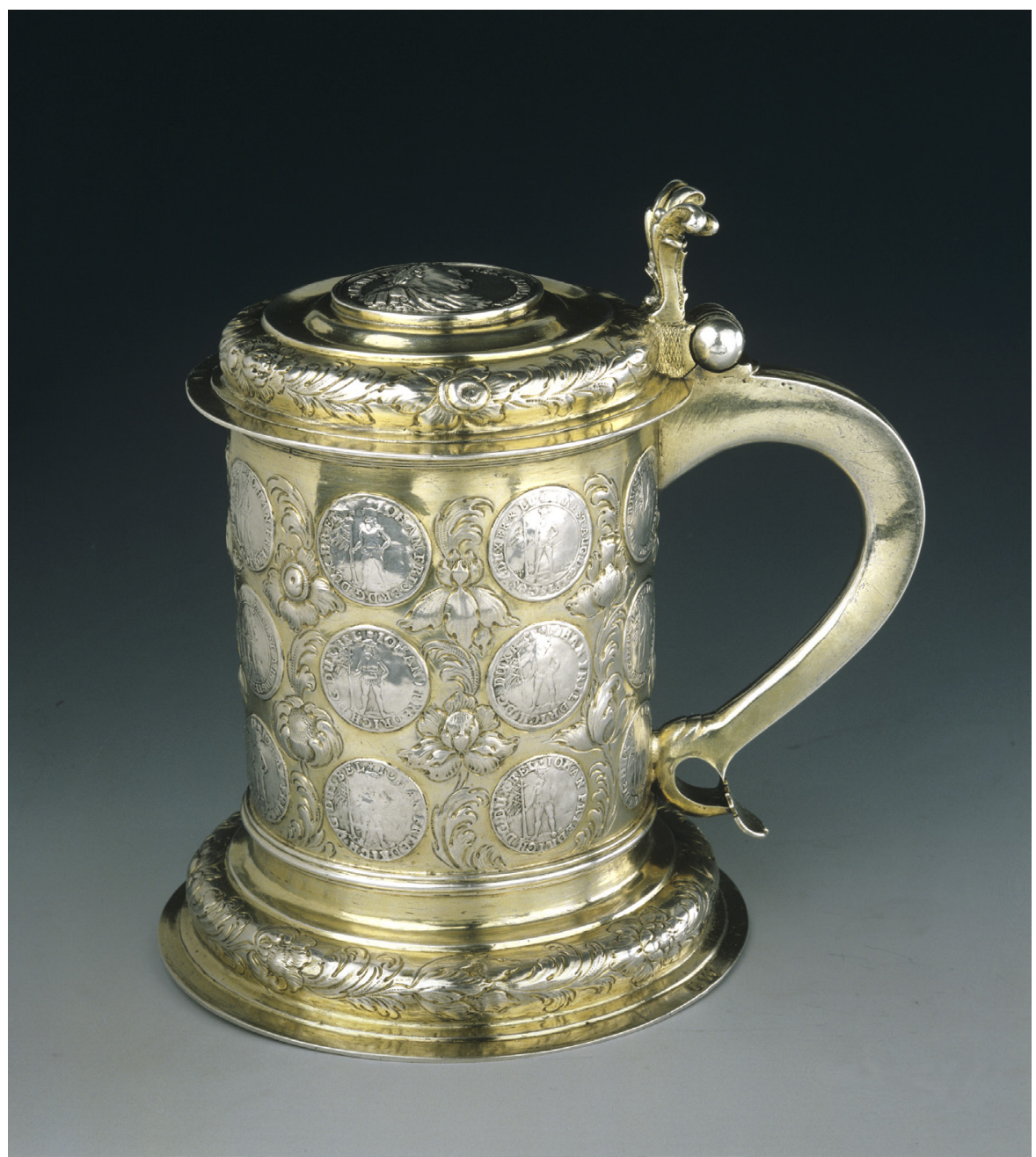

22. Hans (Johann) Meyer, Kufel wysadzany numizmatami, srebro częściowo złocone, Królewiec 1686-1688. Kraków, Zamek Królewski na Wawelu. Państwowe Zbiory Sztuki, nr inw. 8670; przed 2003 w posiadaniu Jerzego Domańskiego, Warszawa; w 1885 w zbiorach A. Lubawina, St. Petersburg. Copyright @ Zamek Królewski na Wawelu. Fot. S. Michta 


\section{Bibliografia}

Adamska, Magdalena. „Maureska - pierwszy triumf grafiki ornamentalnej”. W Ornament i dekoracja dzieła sztuki. Studia z historii sztuki, red. Joanna Daranowska-Łukaszewska, Agata Dworzak i Andrzej Betlej, 163-174. Warszawa: Stowarzyszenie Historyków Sztuki, 2015.

Bielak, Jacek. „Bursztynnictwo gdańskie od drugiej połowy XVI do początku XVIII wieku. Studium z historii nowożytnego rzemiosła artystycznego". Rozprawa doktorska, Uniwersytet Gdański, 2009.

Biskup, Marian, i Gerard Labuda. Dzieje zakonu krzyżackiego w Prusach. Gospodarka społeczeństwo - państwo - ideologia. Gdańsk: Wydawnictwo Morskie, 1988.

Bonczkowska, Żaneta. Mennica toruńska od drugiej połowy XIV wieku do 1454 roku. Lokalizacja - personel - funkcjonowanie. Toruń: Wydawnictwo Adam Marszałek, 2011.

Chrzanowski, Tadeusz, i Marian Kornecki. „Brodnica - nieznany ośrodek złotniczy”. Folia Historiae Artium 17 (1981): 133-145.

Chrzanowski, Tadeusz, i Marian Kornecki. Złotnictwo toruńskie. Studium o wyrobach cechu toruńskiego od wieku XIV do 1832 roku. Warszawa: PWN, 1988.

Cieślak, Katarzyna. Między Rzymem, Wittenberga a Genewą. Sztuka Gdańska jako miasta podzielonego wyznaniowo. Wrocław: Wydawnictwo Leopoldinum Fundacji dla Uniwersytetu Wrocławskiego, 2000.

Clasen, Carl-Heinz. Die mittelalterliche Bildhauerkunst im Deutschordensland Preussen. Die Bildwerke bis zur Mitte des 15. Jahrhunderts. T. 1-2. Berlin: Deutscher Verein für Kunstwissenschaft, 1939.

Czaja, Roman. „Miasta i przestrzeń miejska w państwie zakonu krzyżackiego w Prusach”. W Zakon krzyżacki w Prusach i Inflantach. Podziały administracyjne i kościelne w XIII-XVI wieku, red. Roman Czaja i Andrzej Radzimiński, 81-106. Toruń: Wydawnictwo Naukowe UMK, 2013.

Czaja, Roman. Miasta pruskie a zakon krzyżacki. Studia nad stosunkami między miastem a władza terytorialna w późnym średniowieczu. Toruń: Wydawnictwo UMK, 1999.

Czaja, Roman. „Urbanizacja kraju”. W Państwo zakonu krzyżackiego w Prusach. Władza i społeczeństwo, red. Marian Biskup i Roman Czaja, 177-199. Warszawa: PWN, 2009.

Czihak, Eugen von. Die Edelschmiedekunst früherer Zeiten in Preussen. T. 2 Westpreussen. Leipzig: Verlag von Karl W. Hiersmann, 1908.

Dolczewski, Zygmunt, i Renata Sobczak-Jaskulska. „Monstrancja Jagiełłowa z kościoła Bożego Ciała w Poznaniu”. Kronika Miasta Poznania 68, nr 1 (2000): 36-42.

Dygdała, Jerzy. Adam Stanisław Grabowski (1698-1766). Biskup, polityk, mecenas. Olsztyn: Ośrodek Badań Naukowych im. Wojciecha Kętrzyńskiego, 1994.

Fischinger, Andrzej. „Uwagi nad twórczością Andrzeja Mackensena I złotnika krakowskiego i gdańskiego". Sprawozdania z Posiedzeń Komisji Naukowych PAN, Oddział w Krakowie 13 (1969): 173-175.

Fischinger, Andrzej, i Dariusz Nowacki. Złotnictwo dawnych Prus Królewskich i Książęcych w zbiorach Zamku Królewskiego na Wawelu. Goldsmith's Work from the Former Royal 
and Ducal Prussias in the Collections of the Wawel Royal Castle. Kraków: Zamek Królewski na Wawelu, 2000.

Frąckowska, Anna. Srebrne kufle gdańskie XVII i XVIII wieku. Typologia, stylistyka, ikonografia. Warszawa: Arx Regia, 2013.

Frąckowska, Anna. „Wizerunki Jana III na srebrach gdańskich”. Studia Wilanowskie 25 (2018): 123-151.

Fritz, Johann Michael. Das evangelische Abendmahlsgerät in Deutschland. Vom Mittelalter bis zum Ende des Alten Reiches. Leipzig: Evangelische Verlagsanstalt, 2004.

Fritz, Johann Michael. Goldschmiedekunst der Gotik in Mitteleuropa. München: Verlag C. H. Beck, 1982.

Fuhring, Peter. Juste-Aurèle Meissonnier: un génie du rococo 1695-1750. Turin-London: Umberto Allemandi, 1999.

Fundacje artystyczne na terenie państwa zakonnego w Prusach, red. Barbara Pospieszna. T. 1 Katalog wystawy. T. 2 Eseje. Malbork: Muzeum Zamkowe, 2010.

Goldschmiedekunst des Mittelalters. Im Gebrauch der Gemeinden über Jahrhunderte bewahrt, red. Bettina Seyderhelm. Magdeburg: Evangelische Kirche der Kirchenprovinz Sachsen, Kirchliche Stiftung Kunst- und Kulturgut in der Kirchenprovinz Sachsen, 2001.

Górski, Karol. Zakon krzyżacki a powstanie państwa pruskiego (wyd. I - Wrocław: Ossolineum 1977). Bydgoszcz: Excalibur - Malbork: Muzeum Zamkowe, 2003.

Hubatsch, Walther. Albrecht von Brandenburg-Ansbach. Deutschordens-Hochmeister und Herzog in Preußen 1490-1568. T. 8 Studien zur Geschichte Preußens. Heidelberg: Quelle \& Meyer, 1960.

Jakubek-Raczkowska, Monika. „Die Einflüße Böhmens auf die gotische Skulptur im Ordensland Preussen. Ein Überblick im Lichte der neuesten Forschungen“. W Kunst als Herrschaftsinstrument. Böhmen und das Heilige Römische Reich unter den Luxemburgern im europäischen Kontext, red. Jiři Fajt i Andrea Langer, 550-563. MünchenBerlin: Deutscher Kunstverlag, 2009.

Jakubek-Raczkowska, Monika. Rzeźba gdańska przełomu XIV i XV wieku. Warszawa: Wydawnictwo DiG, 2006.

Jakubek-Raczkowska, Monika. „Sztuka w państwie zakonnym w Prusach w latach 1309-1410. Panorama zjawisk w przededniu tzw. wielkiej wojny”. W Conflictus magnus apud Grunwald 1410. Między historią a tradycją, red. Krzysztof Ożóg i Janusz Trupinda, 39-64. Malbork: Muzeum Zamkowe, 2013.

Jasiński, Janusz. Historia Królewca. Szkice z XIII-XX stulecia. Olsztyn: Książnica Polska, 1994.

Jasiński, Tomasz. „Rozwój złotnictwa toruńskiego do końca XV w.” Acta Universitatis Nicolai Copernici. Historia 11 (1977): 33-51.

Jurkowlaniec, Tadeusz. Gotycka rzeźba architektoniczna w Prusach (Studia z Historii Sztuki. T. 42, red. Jerzy Kowalczyk, Stanisław Mossakowski, Teresa Mroczko i Jerzy Pietrusiński). Wrocław-Warszawa-Kraków-Gdańsk-Łódź: Ossolineum, 1989. 
Kolberg, Joseph. „Ermländische Goldschmiede“. Zeitschrift für Geschichte und Althertumskunde Ermlands 16 (1907): 345-555.

Kopydłowski, Bogusław. „Monstrancja rokokowa”. W Sztuka zdobnicza. Dary i nabytki 1945-1964, red. Stanisław Gebethner, 63. Warszawa: Muzeum Narodowe, 1964.

Krajewski, Wojciech. „Relikwiarz”. W Na znak świetnego zwycięstwa. W sześćsetna rocznicę bitwy pod Grunwaldem, red. Dariusz Nowacki, t. 2, 145-148. Kraków: Zamek Królewski na Wawelu, 2010.

Kriegseisen, Jacek. Słupskie bursztynnictwo. Wyroby słupskiego cechu bursztynniczego od $X V I$ do początku XX wieku. Słupsk: Wydawnictwo Towarzystwa Opieki nad Zabytkami, Oddział w Słupsku, 2002.

Kriegseisen, Jacek. „Złotnictwo elbląskie od XVI do końca XVIII wieku”. W Klejnot w koronie Rzeczypospolitej. Sztuka zdobnicza Prus Królewskich. T. 1 Eseje, red. Czesława Betlejewska, 72-79. Gdańsk: Muzeum Narodowe, 2006.

Kriegseisen, Jacek. „Złotnictwo elbląskie od XIV do początku XIX wieku (do 1827 r.)”. Rozprawa doktorska, Uniwersytet Gdański, 2005.

Kriegseisen, Jacek. „Złotnicy w małych miastach województwa pomorskiego od połowy XVI do końca trzeciej ćwierci XVIII wieku”. W Klejnot w koronie Rzeczypospolitej. Sztuka zdobnicza Prus Królewskich. T. 1 Eseje, red. Czesława Betlejewska, 80-84. Gdańsk: Muzeum Narodowe, 2006.

Kriegseisen, Jacek. „Związki złotników Prus Królewskich z Augsburgiem w XVII i pierwszej połowie XVIII wieku na przykładzie Gdańska, Elbląga i Torunia”. W Ex voto. Studia dedykowane Ojcu Janowi Golonce OSPPE, red. Przemysław Mrozowski i Jerzy Żmudziński, 627-636. Częstochowa: Jasnogórska Fundacja Pro Patria i Wydawnictwo Czuwajmy, 2012.

Kurzawa, Zofia. „Monstrancje-relikwiarze w kościele Bożego Ciała w Poznaniu”. Kronika Miasta Poznania 60, nr 3-4 (1992): 169-189.

Laue, Georg. „Bernsteinarbeiten aus Königsberg für die Kunstkammern Europas: Der Meister Georg Schreiber und seine Werkstatt“. W Bernstein für Thron und Altar. Das Gold des Meeres in fürstlichen Kunst- und Schatzkammern, red. Wilfried Seipel, 23-27. Wien: Kunsthistorisches Museum, Alte Geistliche Schatzkammer, 2006.

Lorentz, Stanisław. „Projets pour la Pologne de Juste-Aurel Meissonier”. Biuletyn Historii Sztuki 20 (1958): 186-198.

Małłek, Janusz. Dwie części Prus. Studia z dziejów Prus Książęcych i Prus Królewskich w XVI i XVII wieku. (Wyd. I - Olsztyn: Wydawnictwo Pojezierze, 1987). Wyd. II - Torun: Wydawnictwo Naukowe UMK, 2015.

Małłek, Janusz. „Königsberg - von der Hauptstadt des Deutschen Ordens zur Residenz und Hauptstadt des Herzogtum Preußen“. W Metropolen im Wandel. Zentralität in Ostmitteleuropa an der Wende vom Mittelalter zur Neuzeit, red. Evamaria Engel, Karen Lambrecht i Hanna Nogossek), 127-133. Berlin: Akademie Verlag, 1995. Wersja polska: „Królewiec na drodze przemian od stolicy państwa zakonu krzyżackiego do stolicy Księstwa Pruskiego i rezydencji książęcej”. W Studia nad dziejami miast 
i mieszczaństwa w średniowieczu. Studia ofiarowane Profesorowi Antoniemu Czacharowskiemu, red. Roman Czaja i Janusz Tandecki, 113-119. Toruń: Wydawnictwo UMK, 1996.

Małłek, Janusz. Prusy Książęce a Prusy Królewskie w latach 1525-1548. Studium z dziejów polskiej polityki księcia Albrechta Hohenzollerna. (Wyd. I - Warszawa: PWN, 1976). Wyd. II - Toruń: Wydawnictwo Naukowe UMK, 2016.

Mierzwińska, Elżbieta. Bursztyn w sztuce. Katalog wybranych obiektów ze zbiorów Muzeum Zamkowego w Malborku. Malbork: Muzeum Zamkowe, 1998.

Nielubszyc, Roman. „Jan Gotfryd Schlaubitz - gdański złotnik XVIII wieku. Biuletyn Historii Sztuki 38 (1976): 239-254.

Okulicz, Małgorzata. Złotnictwo sakralne dominium warmińskiego od połowy XIV do końca XVIII wieku. Katalog wystawy. Olsztyn: Muzeum Warmii i Mazur, 2006.

Piskorska, Józefa. Złotnictwo sakralne na Warmii w okresie baroku. T. 1. Olsztyn: Warmińskie Wydawnictwo Diecezjalne, 2007.

Raczkowski, Juliusz. Monumentalne zespoły kolegium apostolskiego na terenie dawnego państwa zakonnego $w$ Prusach. Pelplin: Wydawnictwo Bernardinum, 2013.

Rohde, Alfred, i Ulla Stöver. Goldschmiedekunst in Königsberg. (Bau- und Kunstdenkmäler des Deutschen Osten. Reihe B, t. 2, red. Günther Grundmann). Stuttgart: W. Kohlhammer, 1959.

Schmidt, Gerhard. „Zu einem Buch über den Meister der Schönen Madonnen“. Zeitschrift für Kunstgeschichte 41 (1978): 61-92; przedruk w: Gerhard Schmidt, Gotische Bildwerke und ihre Meister, 228-268. Wien-Köln-Weimar: Böhlau Verlag, 1992.

Schürer, Ralf. „Der Akeleypokal. Überlegungen zu einem Meisterstück“. W Wenzel Jamnitzer und die Nürnberger Goldschmiedekunst 1500-1700. Goldschmiedearbeiten - Entwürfe, Modelle, Medaillen, Ornamentstiche, Schmuck, Porträts. Eine Ausstellung im Germanischen Nationalmuseum Nürnberg, 107-122. München: Klinkhardt \& Biermann, 1985.

Semrau, Arthur. „Die Bürgerlisten der Stadt Thorn aus dem 17. Jahrhunderte, 1: Die einheimischen Bürger, 2: Die ausländischen Bürger“. Mitteilungen des Coppernicus-Vereins für Wissenschaft und Kunst zu Thorn 27 (1919): 66-82; 28 (1920): 40-70.

Siciński, Mieczysław, i Janusz Trupinda, „Relikwiarz gotycki komtura Thilo von Lorich”. W Imagines potestatis. Insygnia i znaki władzy w Królestwie Polskim i Zakonie Niemieckim, red. Janusz Trupinda, 443-445. Malbork: Muzeum Zamkowe - Bydgoszcz: Markgrafsen, 2007.

Skibiński, Franciszek. Willem van den Blocke. Niderlandzki rzeźbiarz nad Bałtykiem w XVI i na początku XVII w. Toruń: TNT, 2015.

Szczepkowska-Naliwajek, Kinga. Złotnictwo gotyckie Pomorza Gdańskiego, ziemi chełmińskiej i Warmii (Studia z Historii Sztuki. T. 40, red. Wiesław Juszczak, Jerzy Kowalczyk, Teresa Mroczko i Jerzy Pietrusiński). Wrocław-Warszawa-Kraków-Gdańsk-Łódź: Ossolineum, 1987. 
Tandecki, Janusz. Średniowieczne księgi wielkich miast pruskich jako źródła historyczne i zabytki kultury mieszczańskiej. Warszawa-Toruń: IS PAN, 1990.

Tondel, Janusz. Biblioteka zamkowa (1529-1568) księcia Albrechta Pruskiego w Królewcu. Toruń: Wydawnictwo UMK, 1992.

Tondel, Janusz. Srebrna Biblioteka księcia Albrechta Pruskiego i jego żony Anny Marii. Warszawa: BN, 1994.

Torbus, Tomasz. Zamki konwentualne państwa krzyżackiego w Prusach. Gdańsk: Wydawnictwo słowo/obraz terytoria, 2014.

Tylicki, Jacek. Materiały archiwalne do biografii artystów w nowożytnej Brodnicy. Brodnica: Muzeum, 2014.

Walczak, Marek. „Monstrancja”. W Na znak świetnego zwycięstwa. W sześćsetna rocznice bitwy pod Grunwaldem, red. Dariusz Nowacki, t. 2, 159-163. Kraków: Zamek Królewski na Wawelu, 2010.

Woźniak, Michał F. „Art and Liturgy in Teutonic Castle Churches”. W Sacred Space in the State of the Teutonic Order in Prussia, red. Jarosław Wenta, 153-180 (Sacra Bella Septentrionalia. T. 2). Toruń: Wydawnictwo Naukowe UMK, 2013.

Woźniak, Michał F. „Cyborium eucharystyczne”. W Imagines potestatis. Insygnia i znaki władzy w Królestwie Polskim i Zakonie Niemieckim, red. Janusz Trupinda, 448-450. Malbork: Muzeum Zamkowe - Bydgoszcz: Markgrafsen, 2007.

Woźniak, Michał [F.]. „Das Reliquiendiptychon des Elbinger Hauskomturs Thilo von Lorich“. Anzeiger des Germanischen Nationalmuseums (1992): 51-62.

Woźniak, Michał [F.]. „Die Goldschmiedekunst in Norddeutschland, im ehemaligen Ordensland und in Livland. Überlegungen zur Frage: Gibt es einen `hanseatischen Stil'?“. W Hansestadt - Residenz - Industriestandort, red. Beate Störtkuhl, 47-65 (Schriften des Bundesinstituts für Kultur und Geschichte der Deutschen im östlichen Europa. T. 19). München: R. Oldenbourg Verlag, 2002.

Woźniak, Michał [F.]. „Die Goldschmiedekunst in Preussen im Dienste des Ordens, der Kirche und der Städte”. W Mittelalterliche Kultur und Literatur im Deutschordensstaat in Preussen: Leben und Nachleben, red. Jarosław Wenta, Siegelinde Hartmann i Gisela Vollman-Profe, 125-156 (Sacra Bella Septentrionalia. T. 1). Toruń: Wydawnictwo Naukowe UMK, 2008.

Woźniak, Michał F. Die Silberbibliothek aus Königsberg (1545-1562). Bestandkatalog, red. Ruth Slenczka. Potsdam: Haus der Brandenburgisch-Preußischen Geschichte - Petersberg: Michael Imhof Verlag, 2017.

Woźniak, Michał [F.]. „Dyptyk relikwiarzowy elbląskiego komtura domowego Thiele von Loricha“. W Praeterita posteritati. Studia z historii sztuki i kultury ofiarowane Maciejowi Kilarskiemu, red. Mariusz Mierzwiński, 481-500. Malbork: Muzeum Zamkowe, 2001.

Woźniak, Michał [F.]. „Elementy niderlandzkie w złotnictwie gdańskim XVII wieku”. W Studia z historii sztuki i kultury Gdańska i Europy Północnej. Prace poświęcone 
Doktor Katarzynie Cieślak, red. Jacek Friedrich i Edmund Kizik, 239-255. Gdańsk: Stowarzyszenie Historyków Sztuki, Oddział Gdański, 2003.

Woźniak, Michał [F.]. „Liturgische Gefäße der protestantischen Kirchen in Königlich Preußen“. W Kościót i sztuka pobrzeża Bałtyku. Kirche und Kunst im Ostseeraum, red. Michał [F.] Woźniak, 210-254 (Studia Borussico-Baltica Toruniensia Historiae Atrium. T. 3). Toruń: Wydawnictwo UMK, 1998.

Woźniak, Michał [F.]. „Monstrancja eucharystyczna”. W Imagines potestatis. Insygnia i znaki władzy w Królestwie Polskim i Zakonie Niemieckim, red. Janusz Trupinda, 438-440. Malbork: Muzeum Zamkowe - Bydgoszcz: Markgrafsen, 2007.

Woźniak, Michał [F.]. „Prusy Królewskie a Norymberga. Garść uwag o powiązaniach w dziedzinie złotnictwa i o transferze rozwiązań w zakresie typu i formy luksusowych srebrnych przedmiotów”. W Album Amicorum. Między Wilnem a Toruniem. Księga pamiątkowa dedykowana profesorowi Józefowi Poklewskiemu, 375-394. Toruń: Wydawnictwo Naukowe UMK, 2008.

Woźniak, Michał [F.]. „Rozwój formy monstrancji promienistych z warsztatów złotniczych Torunia”. Acta Universitatis Nicolai Copernici. Zabytkoznawstwo i Konserwatorstwo 13 (1989): 121-157.

Woźniak, Michał [F.]. „Sprzęty liturgiczne w kościele SS. Miłosierdzia (d. Benedyktynek) w Chełmnie. Z badań nad złotnictwem na ziemi chełmińskiej XVII-XVIII w.” Acta Universitatis Nicolai Copernici. Zabytkoznawstwo i Konserwatorstwo 10 (1982): 119-160.

Woźniak, Michał [F.]. „Tradycjonalizm i modernizacja sprzętów liturgicznych w Prusach Królewskich w okresie nowożytnym”. W Rozważania o smaku artystycznym, red. Józef Poklewski, Tomasz F. de Rosset, 55-77. Toruń: Wydawnictwo UMK, 2002.

Woźniak, Michał [F.]. „Uwagi o pochodzeniu mistrzów i czeladników gdańskiego cechu złotniczego". Acta Universitatis Nicolai Copernici. Zabytkoznawstwo i Konserwatorstwo 25 (1994): 127-140.

Woźniak, Michał [F.]. „W kwestii złotnictwa norymberskiego w Europie środkowej w XVI wieku”. Teka Komisji Historii Sztuki 9 (2002): 117-145.

Woźniak, Michał [F.]. „Wpływy augsburskie w złotnictwie gdańskim XVII-XVIII stulecia”. Biuletyn Historii Sztuki 47 (1985): 95-126.

Woźniak, Michał [F.]. „Wystrój i wyposażenie zamku malborskiego w świetle rachunków i inwentarzy”. Studia Zamkowe 2 (2006): 54-65.

Woźniak, Michał F. Złotnictwo sakralne Prus Królewskich. Studium typologiczno-morfologiczne. Toruń: Wydawnictwo Naukowe UMK, 2012.

Woźniak, Michał F. „Złotnicy i ich ornament”. W Ornament i dekoracja dzieła sztuki. Studia z historii sztuki, red. Joanna Daranowska-Łukaszewska, Agata Dworzak i Andrzej Betlej, 53-66. Warszawa: Stowarzyszenie Historyków Sztuki, 2015.

Woźniak, Michał [F.]. „Zur Nürnberger Gold- und Silberschmiedekunst des 15. und 16. Jahrhunderts in Mitteleuropa“. Anzeiger des Germanischen Nationalmuseums (2002): 164-176. 